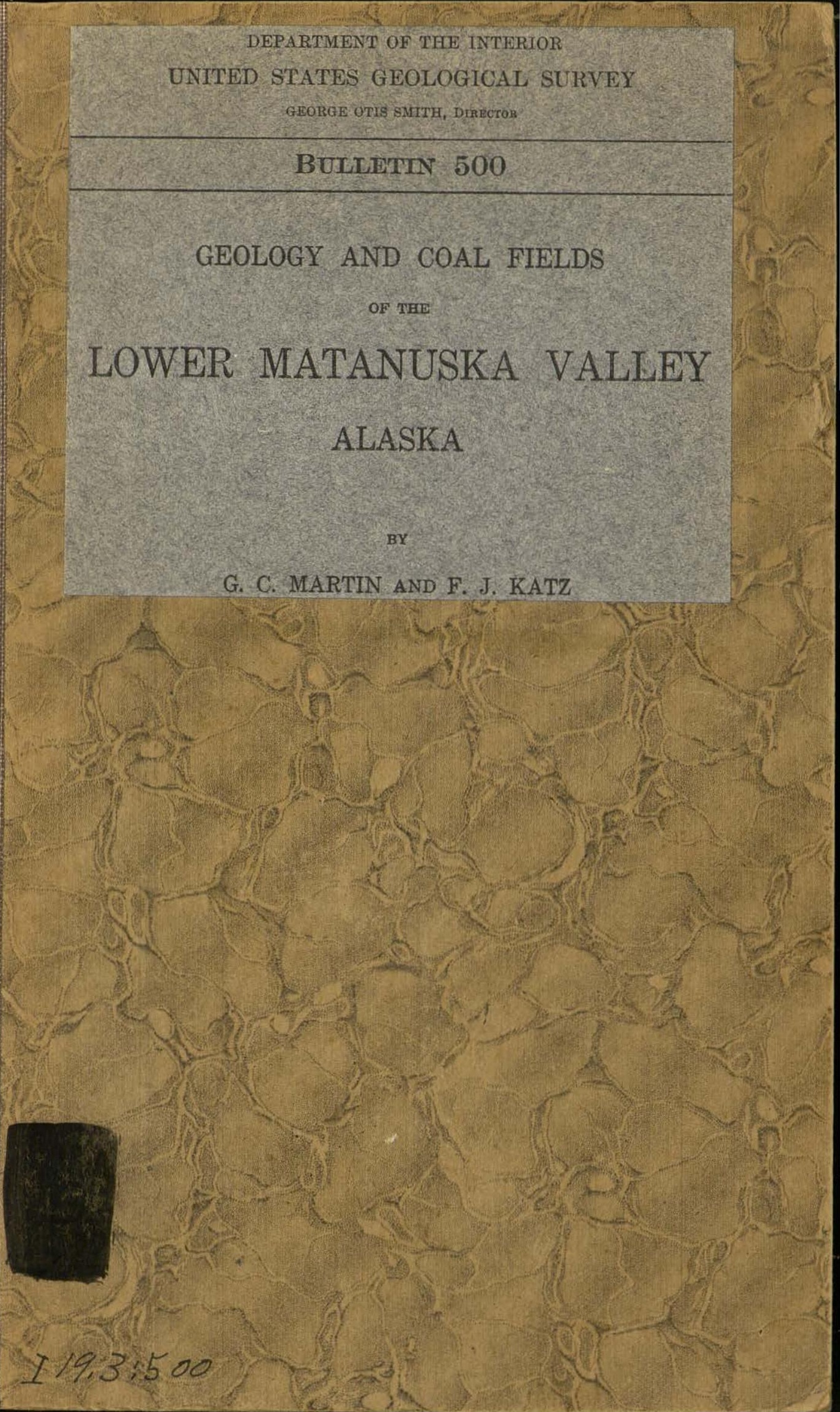




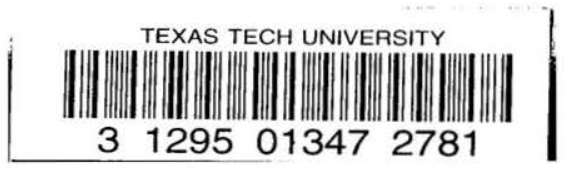


DEPARTMENT OF THE INTERIOR

UNITED STATES GEOLOGICAL SURVEY

GEORGE OTIS SMITH, DIRECTOR

BULLETIN 500

GEOLOGY AND COAL FIELDS

OF THE

\section{LOWER MATANUSKA VALLEY}

ALASKA

BY

G. C. MARTIN AND F. J. KATZ

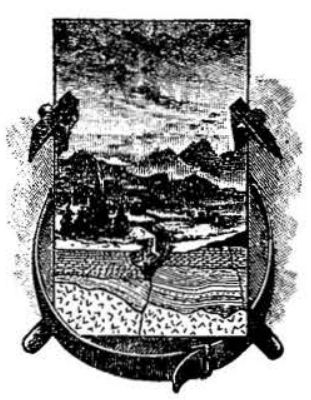

LIBRIARY

TEXAS TECHINOLOGICAL COLLEGE

LUBBOCK, TEXAS

WA SHINGTON

GOVERNMENT PRINTING OFFICE

1912 



\section{CONTENTS.}

Preface, by Alfred H. Brooks.

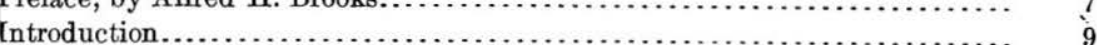

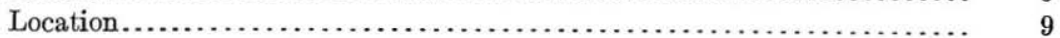

Account of investigations....................................... 9

Exploratory and reconnaissance surveys...................... 9

Detailed surveys..................................... 10

General description of the district.............................. 10

Geography............................................. 10

Climate................................................... 11

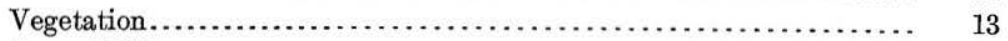

Accessibility............................................. 13

Commercial development................................ 14

Outline of the geology of the Matanuska Valley.................... 14

General features....................................... 14

Mica schists............................................ 15

Graywackes and slates of the Knik River region.................. 16

Lower Jurassic rocks.................................. 17

Granitic rocks ............................................. 19

Middle and Upper Jurassic rocks........................... 20

Lower Cretaceous rocks................................. 22

Upper Cretaceous rocks................................. 23

Tertiary rocks.......................................... 24

Quaternary deposits.................................. 25

Detailed description of the rocks of the lower Matanuska Valley............ 26

Granitic and gneissic rocks..................................... 26

Areal distribution........................................ 26

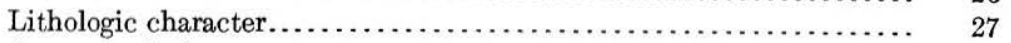

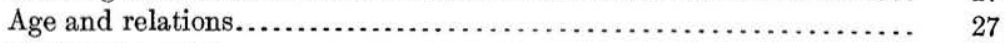

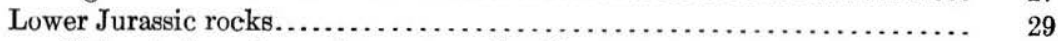

Volcanic breccia, agglomerate and tuff ...................... 29

Areal distribution................................... 29

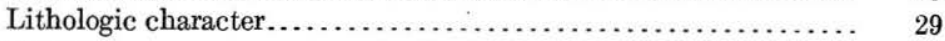

Fauna............................................... 30

Age and correlation...................................... 31

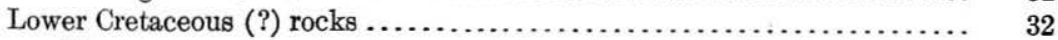

Limestone......................................... 32

Areal distribution................................... 32

Lithologic character.................................... 32

Stratigraphic relations................................. 33

Age and correlation..................................... 33

Upper Cretaceous rocks...................................... 34

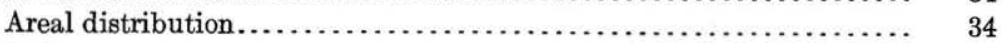

Lithologic character............................................. 34

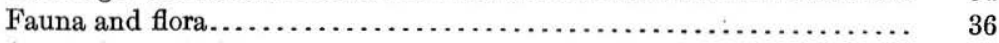

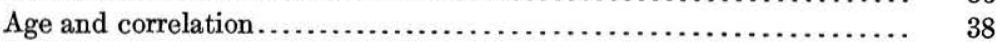


Detailed description of the rocks of the lower Matanuska Valley-Continued. Page.

Tertiary rocks.

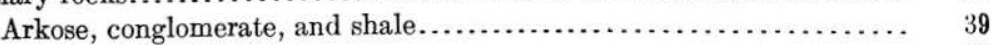

Areal distribution ................................... $\quad 39$

Lithologic character................................. $\quad 39$

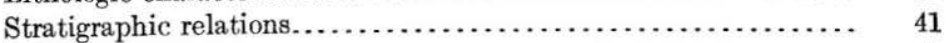

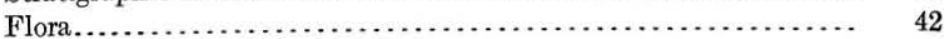

Chickaloon formation.................................... 42

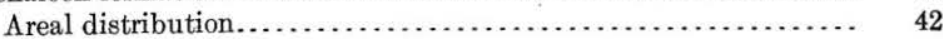

Lithologic character................................. 43

Flora and fauna..................................... 49

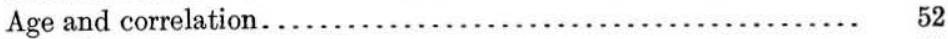

Eska conglomerate...................................... 52

Areal distribution................................... 52

Lithologic character................................ 53

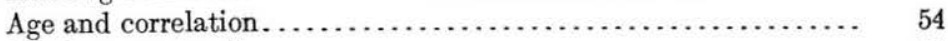

Basaltic lavas and tuffs...................................... 54

Tertiary intrusive rocks................................... 55

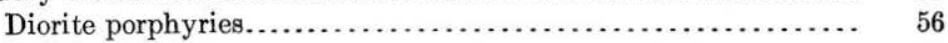

Areal distribution................................ 56

Petrographic character.......................... 56

Local relations................................... 58

Trachytic rocks........................................ 61

Areal distribution................................ 61

Petrographic character............................. 61

Local relations.................................. 62

Diabase and gabbro.................................. 63

Areal distribution................................. 63

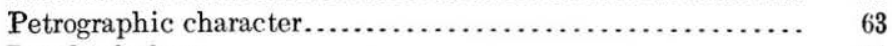

Local relations................................... 64

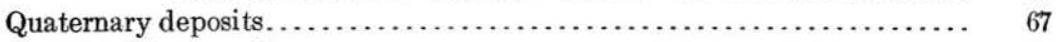

Morainic deposits..................................... 68

Terrace gravels. . . . . . . .

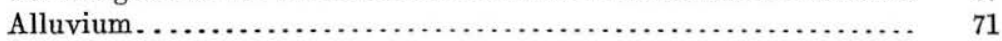

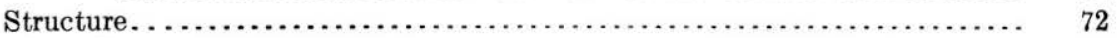

Mineral resources.............................................. 75

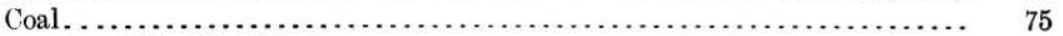

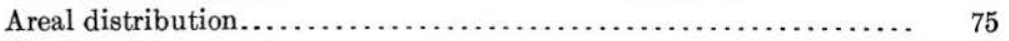

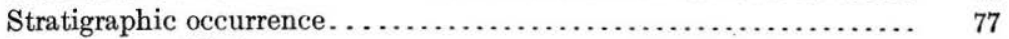

Description of beds................................... 77

Character of the coal. .................................. 88

Physical properties.................................. 88

Chemical analyses and tests........................... $\quad 89$

Coking qualities. . . . . . . . .

Mining conditions. . . . . . . . . . . . . . .

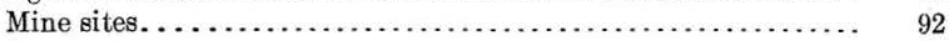

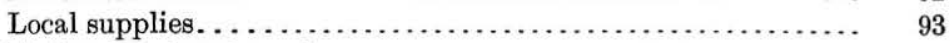

Underground water and gas........................... 93

Effect of intrusive rocks............................. 93

Effect of folding and faulting. . . . .

Metals...................................................... 95

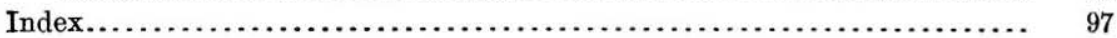




\section{ILLUSTRATIONS.}

Plate I. Map of central Alaska, showing position of the coal fields........

Page.

II. $A$, Talkeetna Mountains from the west side of Kings River; $B$, North wall of Matanuska Valley about 12 miles above Chickaloon River.

II. Geologic reconnaissance map of the Matanuska Valley....... In pocket.

IV. Topographic map of the lower Matanuska Valley........... In pocket.

V. Geologic map of the lower Matanuska Valley ............. In pocket.

VI. $A$, Granite and Tertiary arkose in gulch on the west side of Sheep Valley; $B$, Granite and Tertiary arkose in the west wall of Sheep Valley

VII. $A$, Granite overlain by arkose at the head of Sheep Valley; $B$, Sheep Valley from a point near its lower end................

VIII. $A$, Exposure of arkose in cliffs on north slope of ridge north of Moose Creek; $B$, Gently dipping arkose in west end of ridge north of Moose Creek.

IX. $A$, Eska conglomerate on west wall of valley of Eska Creek, at east end of Wishbone Hill; $B$, Eska conglomerate in west end of Castle Mountain.

X. A, Tertiary lavas, unconformably overlying Eska conglomerate on Castle Mountain; $B$, Eska conglomerate overlain by small cap of Tertiary lava on southeast spur of Castle Mountain......

XI. A, Porphyry sill (?) in valley of Young Creek overlying Chickaloon formation; $B$, Porphyry sills and dikes in Upper Cretaceous rocks on south bank of Matanuska River 2.7 miles below Chickaloon River.

XII. $A$, Diabase dike on fault in Chickaloon formation at base of Castle Mountain; $B$, Diabase dikes and sills in Chickaloon formation on north bank of Boulder Creek.

XIII. $A$, Stratified gravels on east bank of Kings River near lower bridge; $B$, Gravel cliffs on north bank of Matanuska River 1 mile above Moose Creek.

XIV. A, Fault on north edge of Matanuska Valley near headwaters of Young Creek; $B$, Fault between granite and Upper Cretaceous rocks...

XV. Structure sections in lower Matanuska Valley.................

XVI. Structure sections in lower Matanuska Valley.................

XVII. $A$, Coal beds in west bank of Eska Creek 2.7 miles north of Matanuska River; $B$, Coal bed in west bank of Eska Creek 2.4 miles north of Matanuska River

XVIII. Map showing coal areas, location of the coal sections, and localities from which samples were taken................. In pocket.

XIX. $A$, Coal bed in west bank of Chickaloon River at bend above coal camp; $B$, Coal bed in east bank of Coal Creek seven-eighths of a mile above its mouth............................... 
FIGURE 1. Columnar section in summit of Castle Mountain

2. Section in cliff on Young Creek showing relation of diorite porphyry to Tertiary sediments.............................

3. Section on Young Creek showing relation of diorite porphyry to Tertiary sediments......................................

4. Folded beds of the Chickaloon formation and sill..............

5. Diabase sills and dikes in the Chickaloon formation near Chicka-

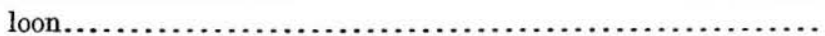

6. Section at south base of Castle Mountain showing relation of gabbro to Tertiary sediments..............................

7. Section along cliff on west bank of Chickaloon River, showing relation of diabase sills to Chickaloon formation...............

8. Section in bank of creek $1 \frac{3}{4}$ miles northwest of Chickaloon, showing relation of gabbro to Chickaloon formation................

9. Section in cliff on east bank of Chickaloon River, showing relation of gabbro to Chickaloon formation..................... 67

10. Gabbro injected into shale, south of Boulder Creek........... 67

11. Diagram of terraces on Moose Creek and on Kings River........ $\quad 70$

12. Sketch showing location of Chickaloon tunnels.............. 78 


\section{PREFACE.}

\section{By Alfred H. Brooks.}

In 1895 the Geological Survey made a preliminary investigation of the coals along the Pacific seaboard of Alaska. The report ${ }^{1}$ published on this subject was the first of a large number which deal primarily or incidentally with the coal deposits of the Territory. In 1902 a systematic study was made of the coal resources of the Yukon. ${ }^{2}$ This was followed in succeeding years by reconnaissance surveys of the coal resources of Admiralty Island, ${ }^{3}$ in southeastern Alaska; of Kachemak Bay ${ }^{4}$ (see Pl. I), of Cape Lisburne, ${ }^{5}$ in northwestern Alaska, and of the Cook Inlet ${ }^{6}$ and Alaska Peninsula regions. ${ }^{7}$ In 1910 a reconnaissance survey of the Nenana coal field ${ }^{8}$ was completed (Pl. I). Meanwhile the more valuable coal fields of Bering River and Matanuska Valley had not been neglected. A preliminary examination of the Bering field was made in $1903^{\circ}$ and of the Matanuska field in $1905^{10}$ and $1906 .{ }^{11}$

The plan of the Survey's Alaskan investigations includes the detailed survey of the most important mining districts. It is believed that so long as there are large areas geologically almost unknown, the detailed surveys, which are expensive of execution, should not be carried on at the cost of too great a curtailment of the reconnaissance work. It is for this reason that the detailed surveys have not been advanced more rapidly. Because of its earlier discovery and greater accessibility the Bering field was surveyed in detail before the Matanuska River field. This survey was completed in $1906 .{ }^{12}$ In

1 Dall, W. H., Report on coal and lignite of Alaska: Seventeenth Ann. Rept. U. S. Geol. Survey, pt. 1, 1896, pp. 763-908.

${ }^{2}$ Collier, A. J., The coal resources of the Yukon, Alaska: Bull. U. S. Geol. Survey No. 218, 1903.

3 Wright, C. W., A reconnaissance of Admiralty Island: Bull. U. S. Geol. Survey No. 287, 1907, pp. 151-154.

4 Stone, R.W., Coal fields of the Kachemak Bay region: Bull. U. S. Geol. Survey No. 277, 1906, pp. 53-73.

${ }^{5}$ Collier, A. J., Geology and mineral resources of the Cape Lisburne region, Alaska: Bull. U. S. Geol. Survey No. 278, 1906.

${ }^{6}$ Atwood, W. W., Mineral resources of southwestern Alaska: Bull. U. S. Geol. Survey No. 379, 1909, pp. 108-152.

7 Atwood, W. W., Geology and mineral resources of parts of Alaska Peninsula: Bull. U. S. Geol. Survey No. $467,1911$.

${ }^{8}$ Capps, S. R., The Bonnifield region, Alaska: Bull. U. S. Geol. Survey No. 501, 1912.

9 Martin, G. C., The petroleum fields of the Pacific coast of Alaska, with an account of the Bering River coal deposits: Bull. U. S. Geol. Survey No. 250, 1905.

10 Martin, G. C., A reconnaissance of the Matanuska coal field, Alaska, in 1905: Bull. U. S. Geol. Survey No. $289,1906$.

il Paige, Sidney, and Knopf, Adolph, Geologic reconnaissance in the Matanuska and Talkeetna basins, Alaska: Bull. U. S. Geol. Survey No. 327, 1907.

12 Martin, G. C., Geology and mineral resources of the Controller Bay region, Alaska: Bull. U. S. Geol. Survey No. $335,1908$. 
1909 the detailed base map of the Matanuska field was prepared, and in 1910 the geologic investigations, whose results are here set forth, were completed. This report forms the second of a series which will set forth the detailed geology of the Alaskan coal fields. The detailed work in any particular field, on which such a report is necessarily based, will not be undertaken until there is promise that the field will be developed in a large way.

The detailed survey of the Matanuska field has fully justified its cost, if only from the fact that it has revealed a much larger area of supposed coal-bearing formations than was previously known. Previous to this survey the area underlain by supposed coal-bearing rocks was roughly estimated at about 50 square miles; now it is estimated to be at least 74 and possibly 98 square miles. (See p. 76.) It has not been determined that all of this area contains workable coal beds, but the survey indicates at least that the coal reserve in this field may be twice as large as previously estimated. In this connection it should be noted that coal is known to occur east of the field here discussed and the coal-bearing area may be considerably larger than is included in the above figures.

The best of the bituminous coals of this field are of the same grade as those of the Bering River field, but from the information at hand they seem to carry a larger percentage of fuels having coking qualities. It was a part of the original plan to have this investigation cover also the anthracite coal of the Matanuska Valley, but time did not permit.

In comparing the commercial value of the Bering River and Matanuska fields, in the matter of distance to tidewater the first has a decided advantage, being only 60 miles from Cordova and 25 from Controller Bay (Pl. I). On the other hand, the rocks in the bestknown part of the Matanuska field seem to be less intricately folded than those of the Bering River field, a condition which makes for cheaper mining. Mr. Martin and Mr. Katz point out (pp. 94-95), to be sure, that the degree of folding in much of the Matanuska field must remain in a large measure unknown until more underground explorations have been made, but this is also true of the Bering River field. If the deformation of the Matanuska field proves to be less intense than that of the Bering River field, this advantage may be in a measure offset by the fact that mining in the Matanuska will be rendered more expensive because of the presence of considerable igneous rock, which is almost entirely absent from the other field. All this points to the necessity of careful and systematic prospecting of each coal tract before any large amount of money is expended on equipment. 


\title{
GEOLOGY AND COAL FIELDS OF THE LOWER MATANUSKA VALLEY, ALASKA.
}

\author{
By G. C. Martin and F. J. Katz.
}

\section{INTRODUCTION.}

\section{LOCATION.}

The area described in this report covers about 200 square miles and is situated in the lower part of the Matanuska Valley, in the south-central part of Alaska. It is about 25 to 50 miles northeast of tidewater at the head of Cook Inlet and about 100 miles north of Seward, which is the nearest large town and the nearest ocean port. (See Pl. I.)

\section{ACCOUNT OF INVESTIGATIONS.}

\section{EXPLORATORY AND RECONNAISSANCE SURVEYS.}

The investigations which were made with the purpose of preparing this report were preceded by other surveys through which the general features of this district have already been made known and which have contributed in no small degree to the results presented below.

The Matanuska Valley was traversed in 1898 by W. C. Mendenhall, who was attached as geologist to "military expedition No. 3 " in charge of Capt. Edwin F. Glenn, Twenty-fifth Infantry, United States Army. Mendenhall's explorations covered areas on the west shore of Prince William Sound and a route extending from Resurrection Bay to the head of Turnagain Arm, thence by way of Glacier and Yukla Creeks to Knik Arm, up the Matanuska Valley to its head, and thence northward to the Tanana. Mendenhall's account ${ }^{1}$ of his explorations includes a description of the general geologic and geographic features, accompanied by a topographic map on the scale of 1 to 625,000 .

The coal of the lower Matanuska Valley was studied by G. C. Martin in a reconnaissance made in August, 1905. Martin's report ${ }^{2}$

\footnotetext{
${ }_{1}$ Mendenhall, W. C., A reconnaissance from Resurrection Bay to the Tanana River, Alaska, in 1898: Twentieth Ann. Rept. U. S. Geol. Survey, pt. 7, 1900, pp. 265-340.

2 Martin, G. C., A reconnaissance of the Matanuska coal field, Alaska, in 1905: Bull. U. S. Geol. Survey No. 289, 1906.
} 
includes a brief account of the geology and geography of the area covered by his work and a more extensive description of the coal, including detailed measurements of many coal beds and analyses of representative samples.

This region was visited again in 1906 by a Geological Survey party which mapped, topographically and geologically, on the reconnaissance scale (1 to 250,000), the entire Matanuska and Talkeetna valleys, as well as part of the mountains bordering the western edge of the Copper River basin north of the Matanuska Valley. This expedition, which was in charge of T. G. Gerdine, topographer, was accompanied by R. H. Sargent, topographer, and by Sidney Paige and Adolph Knopf, whose report ${ }^{1}$ on the geology described for the first time an approximately complete section of the Mesozoic and Tertiary rocks and was accompanied by a geologic map showing the areal distribution of the larger geologic units.

\section{DETAILED SURVEYS.}

The detailed topographic map (Pl. IV, in pocket), which was used as the base for the subsequent geologic surveys, was made by $\mathrm{R}$. H. Sargent in 1909.

The detailed geologic investigations which are the chief basis of the discussion presented in the following pages were made in the summer of 1910 by G. C. Martin, geologist; F. J. Katz, assistant geologist; and Theodore Chapin, geologic field assistant. The party also included a cook and two packers. The field season extended from June 3 to September 11.

\section{GENERAL DESCRIPTION OF THE DISTRICT.}

GEOGRAPHY.

Matanuska River is tributary to Knik Arm, at the head of Cook Inlet. It rises on the western edge of the Copper River basin and flows between the Talkeetna Mountains on the north and the Chugach Mountains on the south. The Matanuska is about 80 miles in length and has a drainage basin of about 1,000 square miles. Its fall in the part of its course included in the area here described in detail is about 20 feet to the mile. This rapid fall gives it a swift current, because of which and of its being overloaded with sediment and consequently being in most places broken up into many shifting channels over an aggrading flood plain, it is not navigable. The fall is, however, so evenly distributed that there is no available water power.

The principal tributaries of the Matanuska are Caribou Creek, Hicks Creek, Chickaloon River, and Kings River, of which the last two enter it within the area here described in detail. The other

1 Paige, Sidney, and Knopf, Adolph, Geologic reconnaissance in the Matanuska and Talkeetna basins, Alaska: Bull. U.S. Geol. Survey No. 327, 1907. 


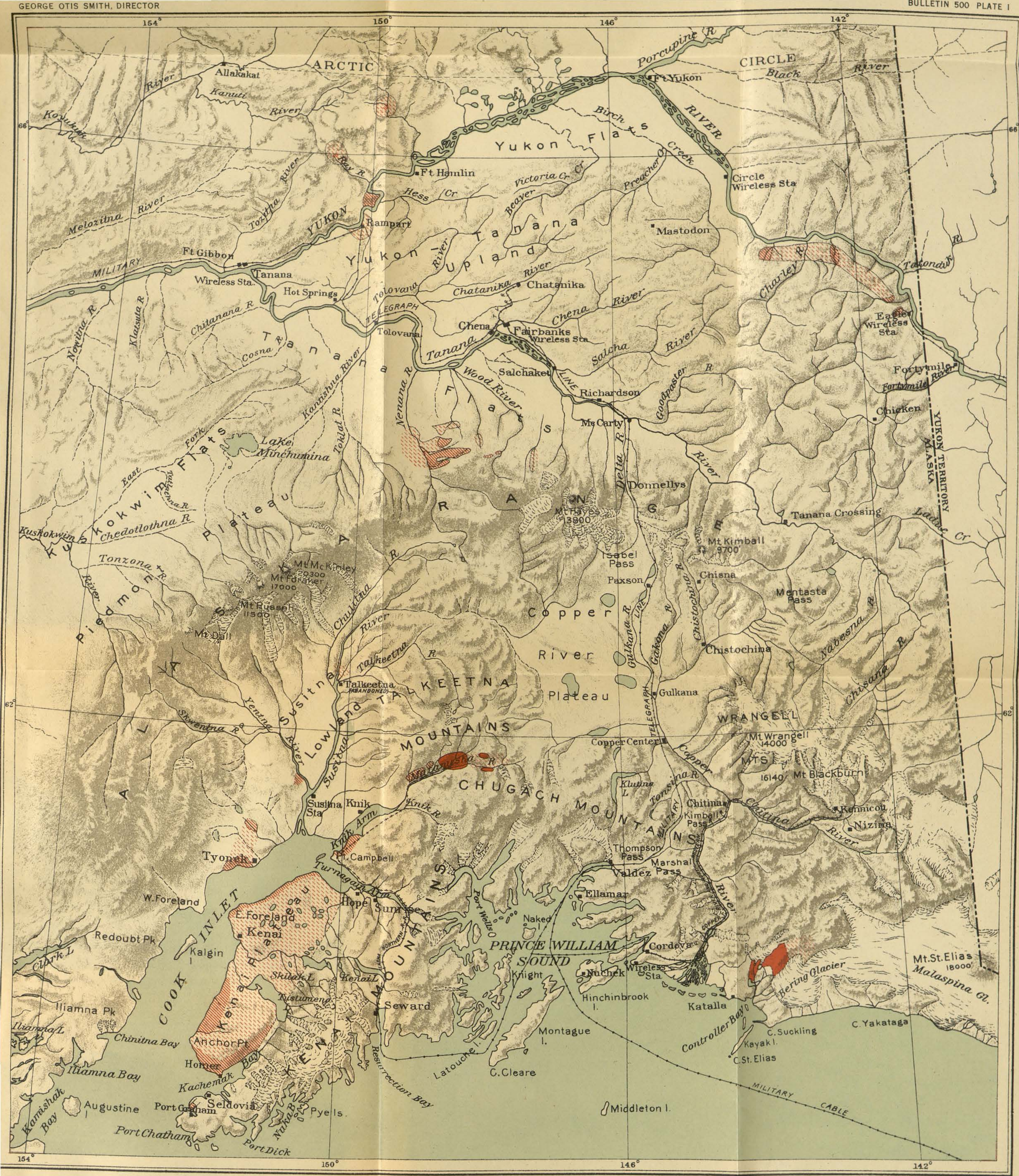

MAP OF CENTRAL ALASKA, SHOWING POSITION OF THE COAL FIELDS

Scale $\frac{1}{2,500,000}$

25 



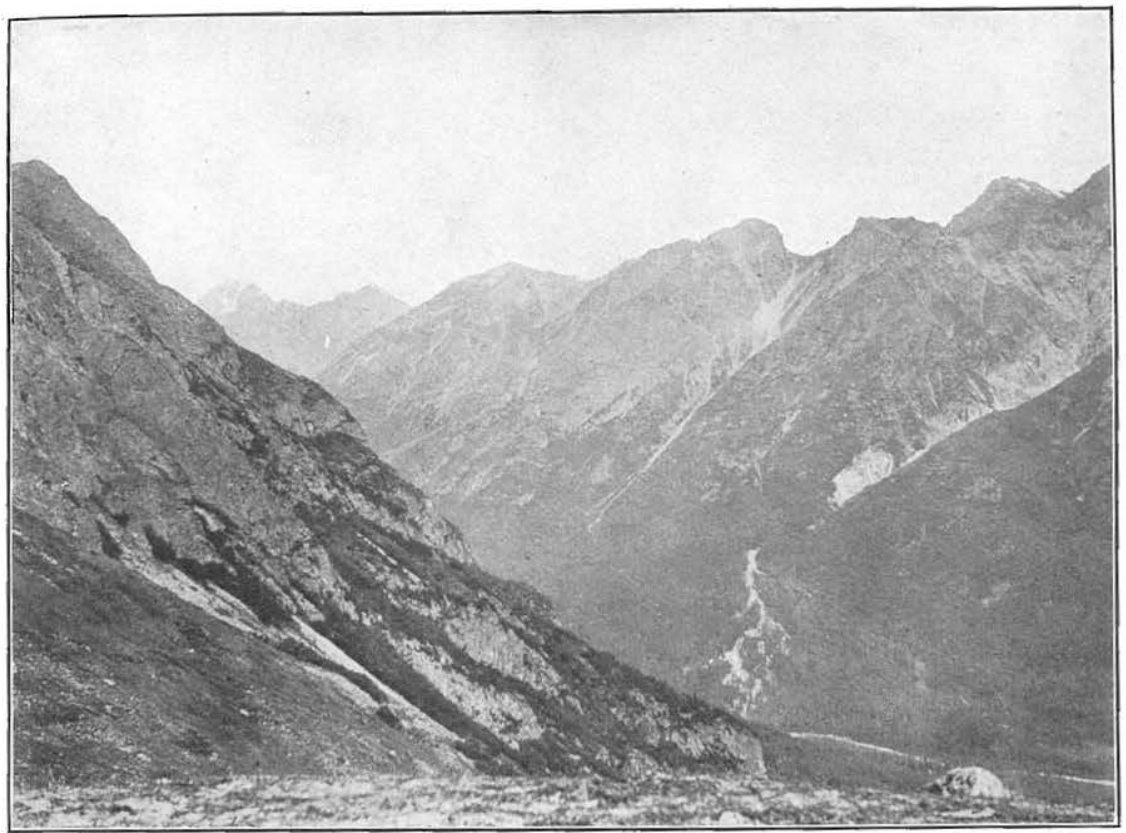

A. TALKEETNA MOUNTAINS FROM THE WEST SIDE OF KINGS RIVER.

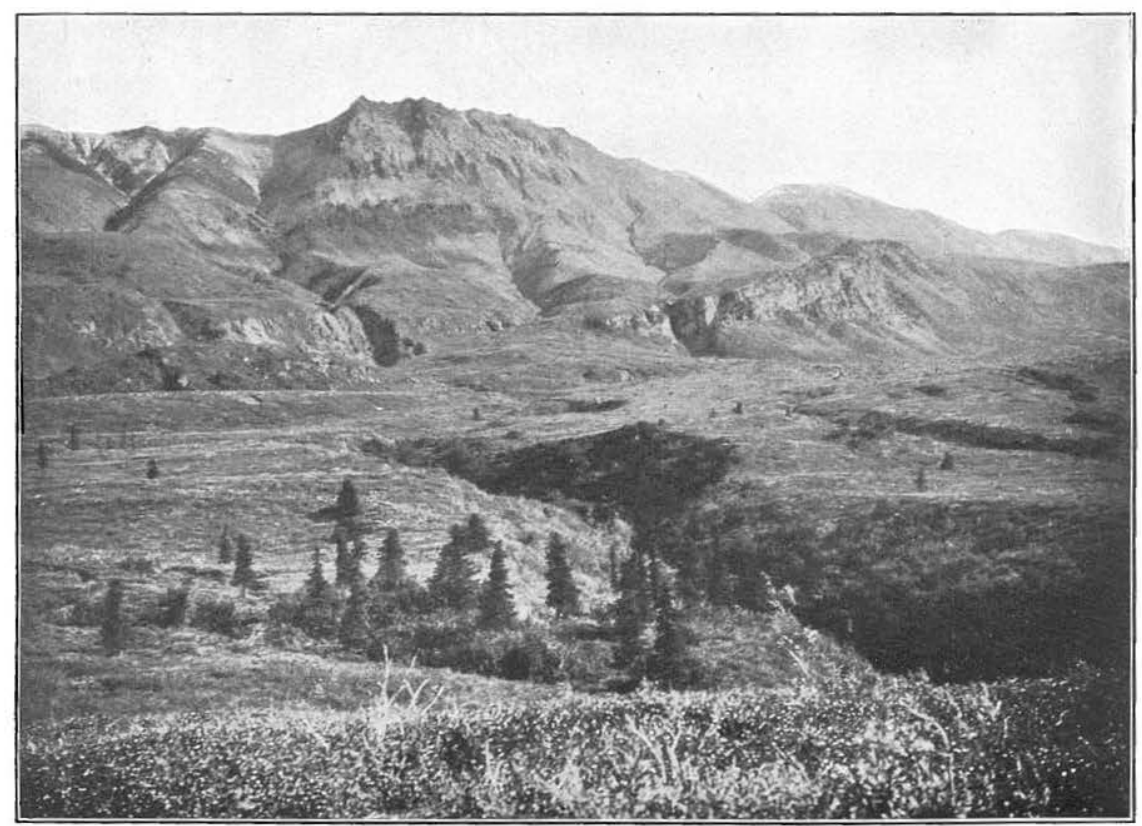

B. NORTH WALL OF MATANUSKa VALLEY ABOUT 12 MILES ABOVE CHICKALOON RIVER. 

tributaries which it receives in this area are Coal, Carbon, Granite, Eska, and Moose creeks. It is a noteworthy fact that the larger tributaries of the Matanuska all enter it from the north.

The Matanuska drainage basin may be divided into the mountain areas and the valley areas. The mountain areas include part of the Chugach Mountains south of the river and the Talkeetna Mountains north of it. (See Pl. II, A.) The latter are divided by the valley of Chickaloon River into two topographically dissimilar parts which will be shown below to be geologically unlike. The mountains west of Chickaloon River are in general higher and more rugged than those to the east. The height of the summits is in general from 6,000 to 8,000 feet west of Chickaloon River and from 5,000 to 7,000 feet east of it. The general altitude of the summits of that part of the Chugach Mountains which lies in the Matanuska drainage basin is from 7,000 to 8,000 feet.

The Matanuska Valley proper has a general width of about 6 miles between approximately parallel and fairly distinct mountain fronts. Within it are rounded hills and gravel-covered flats, the former rising to elevations ranging between about 2,300 and 3,500 feet and the latter to about 1,200 feet, although small gravel-covered benches are present at the mouths of some of the tributary valleys at elevations as great as 2,200 feet. The streams occupy narrow valleys within this broader valley and some of these are box canyons. It is noteworthy that the Matanuska practically throughout its course is nearer the south than the north wall of the valley, in most places hugging the south wall.

At Moose Creek the valley opens out into the Cook Inlet flats, a gravel-covered lowland in which the irregular hills and ridges rise to elevations in few places exceeding 200 or 300 feet. Between these hills are many marshy flats.

CLIMATE.

The Matanuska Valley, lying as it does back from the ocean, has a climate more like that of the interior of Alaska than that of the coast. The summer temperatures are rather mild; the winters are severe. The precipitation is light, especially in the summer, when, although cloudy days are not infrequent, there is sometimes only a few inches of rainfall during the whole summer. The snowfall is said to be moderate, a total of 3 or 4 feet usually accumulating annually.

The following table is a summary of observations kindly furnished by Mr. Frank Watson and published by Alfred H. Brooks. ${ }^{1}$

1 Brooks, A. H., The Mount McKinley region, Alaska: Prof. Paper U. S. Geol. Survey No. 70, 1911, pp. 196-198. 
THE LOWER MATANUSKA VALLEY, ALASKA.

Summary of meteorological observations at Chickaloon.

\begin{tabular}{|c|c|c|c|c|c|c|c|c|}
\hline \multirow{3}{*}{ Date. } & \multicolumn{6}{|c|}{ Temperature ( $\left.{ }^{\circ} \mathrm{F}.\right)$. } & \multirow{3}{*}{$\begin{array}{l}\text { Days with precipita- } \\
\text { tion. }\end{array}$} & \multirow{3}{*}{$\begin{array}{l}\text { Clear } \\
\text { days. }\end{array}$} \\
\hline & \multicolumn{3}{|c|}{6 a. m. } & \multicolumn{3}{|c|}{ Noon. } & & \\
\hline & $\begin{array}{l}\text { Maxi- } \\
\text { mum. }\end{array}$ & $\begin{array}{l}\text { Mini- } \\
\text { mum. }\end{array}$ & Mean. & $\begin{array}{l}\text { Maxi- } \\
\text { mum. }\end{array}$ & $\begin{array}{l}\text { Mini- } \\
\text { mum. }\end{array}$ & Mean. & & \\
\hline $\begin{array}{l}1907 . \\
\text { October } 25-31 \ldots \ldots \ldots \\
\text { November.............. } \\
\text { December........... }\end{array}$ & $\begin{array}{l}36 \\
34 \\
36\end{array}$ & $\begin{array}{r}10 \\
-3 \\
-30\end{array}$ & $\begin{array}{r}27 \\
15 \\
8\end{array}$ & $\begin{array}{l}42 \\
40 \\
32\end{array}$ & $\begin{array}{r}17 \\
3 \\
-28\end{array}$ & $\begin{array}{l}32 \\
15 \\
10\end{array}$ & 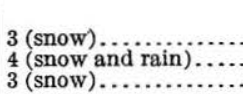 & $\begin{array}{r}1 \\
12 \\
18\end{array}$ \\
\hline 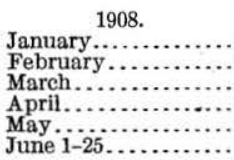 & $\begin{array}{l}29 \\
32 \\
30 \\
42 \\
50 \\
62\end{array}$ & $\begin{array}{r}-26 \\
-21 \\
-3 \\
8 \\
32 \\
44\end{array}$ & $\begin{array}{r}8 \\
10 \\
13 \\
29 \\
42 \\
52\end{array}$ & $\begin{array}{l}30 \\
46 \\
43 \\
52 \\
64 \\
78\end{array}$ & $\begin{array}{r}-15 \\
-6 \\
10 \\
36 \\
46 \\
50\end{array}$ & $\begin{array}{l}15 \\
36 \\
32 \\
44 \\
55 \\
61\end{array}$ & 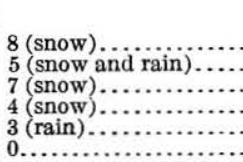 & $\begin{array}{l}12 \\
14 \\
15 \\
20 \\
14 \\
12\end{array}$ \\
\hline
\end{tabular}

Monthly snowfall at Chickaloon.

Inches.

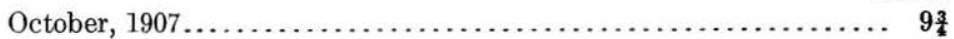

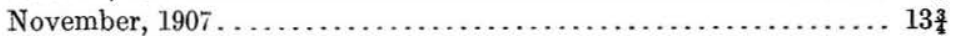

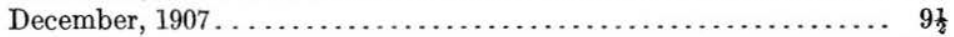

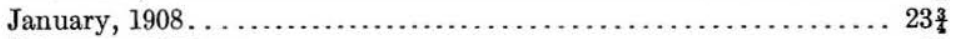

February, 1908................................. $8 \frac{3}{6}$

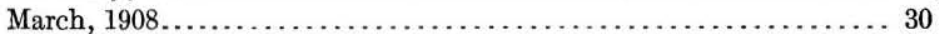

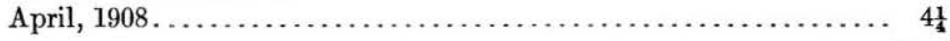

$99 \frac{3}{4}$

March 23, 1908, 3 feet 4 inches of snow on the level; April 14, 1908, 2 feet 6 inches of snow on the level.

The United States Weather Bureau has courteously supplied the observations made by $\mathrm{H}$. H. Hicks at Chickaloon during the period from March, 1910, to March, 1911. They are summarized in the following table:

Summary of meteorological record at Chickaloon, Alaska, March, 1910-March, 1911.

\begin{tabular}{|c|c|c|c|c|c|c|c|c|c|c|c|c|c|}
\hline \multirow[b]{2}{*}{ Months. } & \multicolumn{5}{|c|}{ Temperature $\left({ }^{\circ} \mathrm{F}.\right)$. } & \multirow{2}{*}{ 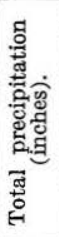 } & \multicolumn{3}{|c|}{ Snow (inches). } & \multirow{2}{*}{ 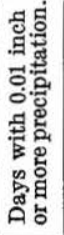 } & \multirow[b]{2}{*}{ 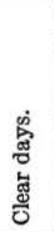 } & \multirow{2}{*}{ 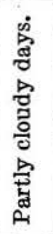 } & \multirow[b]{2}{*}{ 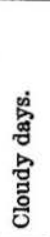 } \\
\hline & 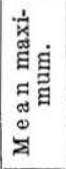 & 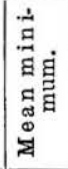 & 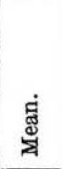 & $\begin{array}{l}\text { 禀 } \\
\text { 夏 } \\
\text { 莺 }\end{array}$ & 鴶 & & 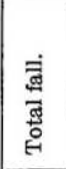 & 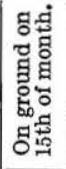 & 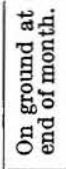 & & & & \\
\hline $\begin{array}{r}1910 . \\
\text { March....... }\end{array}$ & 32.3 & 20.3 & 26.3 & 50 & -12 & & 7 & 38 & 32 & & 17 & 6 & \\
\hline April. & 40.1 & 15. 2 & 27.7 & 54 & $\begin{array}{l}-12 \\
-8\end{array}$ & $\begin{array}{r}0.05 \\
.20\end{array}$ & t & $\begin{array}{l}30 \\
30\end{array}$ & $\begin{array}{l}52 \\
12\end{array}$ & 2 & 15 & 9 & 6 \\
\hline May. & 58.2 & 31.6 & 44.9 & 78 & 24 & .12 & & & & $\overline{2}$ & 11 & 11 & 9 \\
\hline June & 62.2 & 39.1 & 50. & 71 & 26 & 1. 19 & & & $\ldots$ & 7 & 6 & 8 & 16 \\
\hline July & 69.1 & 45.2 & 57.2 & 84 & 38 & 1.42 & & .... & $\cdots$ & 10 & 11 & 7 & 13 \\
\hline Augus & 67.1 & 40.2 & 53.7 & 79 & 30 & .49 & $\cdots$ & .. & $\ldots$ & 4 & 13 & 10 & 8 \\
\hline Sept & 59. & 34.4 & 46 & 84 & 21 & 1.46 & & & ...... & 8 & 11 & 9 & 10 \\
\hline Octo & 38. & 20.9 & 29 . & 5 & -7 & .71 & & & 3 & 3 & 8 & 10 & 13 \\
\hline Novem & 22. & 6.6 & 14.7 & 34 & -5 & .27 & 6.5 & 4 & 6 & 3 & 17 & 4 & 9 \\
\hline December....... & 15.5 & 0 & 7.8 & 34 & -25 & .51 & 9 & 9 & 11 & 3 & 16 & 4 & 11 \\
\hline 1911. & & & & & & & & & & & & & \\
\hline January .................. & 12.3 & -5.2 & $\begin{array}{r}3.6 \\
13.7\end{array}$ & 29 & -33 & .84 & 13 & 12 & 19 & 4 & 18 & 4 & $\theta$ \\
\hline 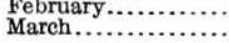 & $\begin{array}{l}24.2 \\
26.4\end{array}$ & $\begin{array}{l}3.1 \\
1.7\end{array}$ & 14.1 & $\begin{array}{l}42 \\
43\end{array}$ & $\begin{array}{l}-28 \\
-27\end{array}$ & $\begin{array}{l}2.47 \\
1.15\end{array}$ & $\begin{array}{l}24 \\
18\end{array}$ & $\begin{array}{l}22 \\
34\end{array}$ & $\begin{array}{l}24 \\
30\end{array}$ & $\begin{array}{l}9 \\
6\end{array}$ & $\begin{array}{r}9 \\
16\end{array}$ & $\begin{array}{l}0 \\
4\end{array}$ & 11 \\
\hline
\end{tabular}


VEGETATION.

Timber line in this area is at a general elevation of 2,000 to 2,500 feet, above which there is the customary growth of small bushes, moss, and grass. The trees include spruce, birch, and several kinds of cottonwood. The growth is in general not dense. Most of the spruce trees are under 12 inches in diameter, the largest one which the writers noted having a circumference of 5 feet. The timber is probably sufficient for any local demands that can now be foreseen, provided that forest fires, which the dry climate favors, are kept under control. There is no timber suitable for export.

The more open birch forests, as well as the areas which have lately been burned, are covered with a dense growth of grass. These natural meadows are large enough to furnish feed for whatever stock is likely to be locally needed.

\section{ACCESSIBILITY.}

The Matanuska Valley is at present reached from Knik, which is the head of navigation on Cook Inlet and to which vessels of shallow draft can go at high tide. Near the lower end of Knik Arm there. is a good anchorage, which ocean-going vessels can reach at any stage of the tide except during the winter, when the whole upper part of Cook Inlet is frozen.

There is a good horse trail from Knik to the upper end of Matanuska Valley, and the character of the ground and of the vegetation is such that this trail could be made into a wagon road at comparatively slight expense. It takes horses from one to two days to reach Moose Creek, depending on the load, and from a day to a day and a half to go from Moose Creek to Chickaloon River.

At present freight can not be taken in while Cook Inlet is frozen, which is usually from October 15 to May 15, and passengers can reach the region during the winter only by going in from Seward with sleds.

The Alaska Northern Railroad, which is now completed from Seward to Kern Creek, on the north shore of Turnagain Arm, a distance of 72 miles, is intended to reach Matanuska Valley, to which surveys have been made; some construction work has been done between Kern Creek and Knik Arm. According to the present surveys it will be about 150 miles from Seward to Chickaloon River. When this road is completed the Matanuska Valley will be easily accessible at any time of the year. 


\section{COMMERCIAL DEVELOPMENT.}

The present interest in this region lies chiefly in the coal fields. One of the purposes of the railroad was the development of these coal fields and until they are developed there will probably not be sufficient freight to justify the completion of the road.

The only present inhabitants of the Matanuska Valley are men who are interested in the coal. The town of Knik, although dependent partly for its support on the prospectors in the coal fields, is also the local shipping and supply point for the gold fields on Willow Creek. The latter are at present the chief support of the town.

OUTLINE OF THE GEOLOGY OF THE MATANUSKA VALLEY.

\section{GENERAL FEATURES.}

The Matanuska drainage basin and the region immediately contiguous to it may be divided into three mountainous and three lowland provinces. The major areal division is that by Matanuska River, into the Chugach Mountains south of the river and the Talkeetna Mountains north of it. The Talkeetna Mountains are divided by the valley of Chickaloon River into two physiographically and geologically dissimilar parts. The three lowland provinces are (1) the valley of the Matanuska from its source to the point where it emerges from between the Chugach and Talkeetna mountains, (2) the lower Matanuska and Knik Arm flats, and (3) the Copper River Plateau, on the western margin of which Matanuska River has its source.

West of Chickaloon River the Talkeetna Mountains are probably composed chiefly of granite, although metamorphic rocks are known to be present. East of the Chickaloon the Talkeetna Mountains are made up of Jurassic sediments, overlain in parts of the area by late Tertiary volcanic rocks. The geology of that part of the Chugach Mountains which lies within this region is practically unknown, but the rocks are probably chiefly erystalline and largely metamorphic.

The less mountainous area adjacent to Matanuska River contains mainly Tertiary and Mesozoic sediments. The area described in detail in this report lies chiefly within this province.

The Knik Arm flats and the Copper River plateau are covered with Quaternary gravels and the nature of the underlying rocks is unknown. 
The accompanying geologic map (Pl. III, in pocket) shows the areal distribution of the rocks throughout the Matanuska Valley. The general stratigraphic sequence is given in the following table:

Stratigraphic sequence in the Matanuska Valley.

\begin{tabular}{|c|c|c|c|}
\hline \multicolumn{2}{|r|}{ Age. } & \multirow[t]{2}{*}{ Lithologic character. } & \multirow[t]{2}{*}{$\begin{array}{l}\text { Thickness } \\
\text { (feet). }\end{array}$} \\
\hline Quaternar & & & \\
\hline \multirow{3}{*}{ Tertiary. } & Pliocene (?). & 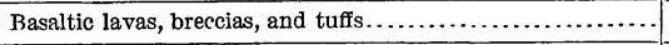 & $800+$ \\
\hline & Miocene (?). & 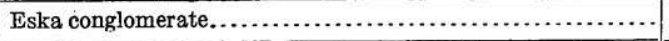 & 2,500 \\
\hline & Focene. & $\begin{array}{l}\text { Chickaloon formation; } a \text { shale and sandstone, coal bearing..... } \\
\text { Arkose, conglomerate, and shale.............................. }\end{array}$ & $\begin{array}{l}2,000 \pm \\
2,000 \pm\end{array}$ \\
\hline \multicolumn{2}{|c|}{ Upper Cretaceous. } & 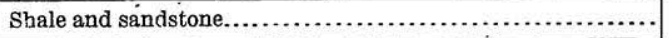 & $4,500 \pm$ \\
\hline \multicolumn{2}{|c|}{ Lower Cretaceous. } & Limestone.................................................... & $300+$ \\
\hline \multicolumn{2}{|c|}{ Upper Jurassic. } & Shale, sandstone, and conglomerate........................ & $2,000 \pm$ \\
\hline \multicolumn{2}{|c|}{ Middle Jurassic. } & Sandstone and shale...................................... & $1,000 \pm$ \\
\hline \multicolumn{2}{|c|}{ Lower Jurassic. } & 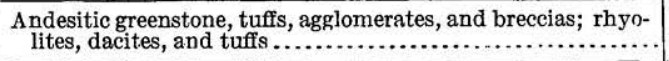 & $1,000+$ \\
\hline \multicolumn{2}{|c|}{ Early Mesozoic or older. } & Graywackes, slates, basaltic greenstones, and rhyolites and tuffs & (?) \\
\hline \multicolumn{2}{|l|}{ Paleozoic. } & Mica schists and other schistose and gneissic rocks............. & $(?)$ \\
\hline
\end{tabular}

$a$ Carries Kenai flora.

MICA SCHISTS.

Mica schists form a narrow belt, not over 3 miles wide, near the head of Willow Creek. This belt has an east-west direction, is not known to extend farther east than Little Susitna River, and disappears westward beneath the gravel floor of Susitna Valley.

These schists include garnetiferous mica schists and chlorite-albite schists. They are thoroughly foliated rocks of medium grain and show in general no variations in appearance.

The strike of the schistosity varies from N. $45^{\circ} \mathrm{E}$. to N. $60^{\circ} \mathrm{W}$. The dips average near $40^{\circ}$ but are inclined on both sides of the vertical. Fossils have not been obtained in these rocks, nor is their occurrence likely. On account of the thorough metamorphism it has undergone, which considerably exceeds that of any of the rocks presently to be described, this formation is regarded as representing the oldest rocks of the region. Its members show a petrographic similarity to the mica schists of the Yukon-Tanana region, and a possible correlation with the pre-Ordovician of that region is suggested. 
GRAYWACKES AND SLATES OF THE KNIK RIVER REGION. ${ }^{1}$

The rocks on the south side of Knik Arm and in the valley of Knik River consist largely of graywackes, slates, and phyllites, with some greenstones, rhyolites, and tuffs. The general strike of the series $\left(\mathrm{N} .60^{\circ} \mathrm{E}\right.$.) tends to carry them eastward approximately parallel to the course of Matanuska River. Their occurrence farther east is indicated by the fact that the moraine of the great glacier at the head of Knik Valley is composed exclusively of graywacke and slate.

The graywackes are highly indurated rocks, whose most conspicuous feature to the unaided eye is the unusual abundance of small angular slate fragments. They are dark bluish gray and at some. places are not easily distinguishable from basic volcanic rocks. The graywackes are roughly schistose and pass by increasing fineness of grain into graywacke slates and highly cleaved clay slates. Locally the slates assume a schistose foliation, become glossy, and pass into phyllites. At Knik Glacier they are affected by slip-strain cleavage and are acutely crumpled and contorted. The interbedded graywacke, however, has been rendered only roughly schistose. Quartz stringers are very abundant in the slates and graywackes and at places form an intricate network of small veins, averaging about an inch in thickness. Mineralization of the quartz is not visible to the eye.

Near the mouth of Knik River a great volume of greenstone tuffs, estimated as probably 1,500 feet thick, was found associated with the graywackes. They are dense, fine-grained rocks of green color, conspicuous on account of the numerous angular fragments of black slate which they inclose.

The massive greenstones are, as a rule, nonporphyritic rocks of aphanitic texture. The original structure is in places obscured by abundant developments of secondary minerals, such as light-green hornblende, chlorite, and epidote, but remnants of ophitic or closely allied textures are sufficiently well preserved to leave no doubt as to the original character of the rock.

Rhyolites and their tuffs are associated with slates at a locality halfway up Knik River. The acidic volcanic rocks are of felsitic habit and include flow-banded types and porphyritic phases with inconspicuous quartz phenocrysts. A rude schistosity has been impressed on them.

The tuffs accompanying the rhyolites, like the greenstone tuffs, are remarkable for the abundance of small, angular slate fragments which they include. Microscopic study indicates that the rhyolite tuffs grade into graywackes. A transitional type is represented by a rock in which glassy quartzes and white feldspars are studded in porphyritic fashion in a dense greenish matrix.

1 These rocks have not been studied by the authors of this report, and the description here given is an abstract of that by Paige and Knopf (Bull. U. S. Geol. Survey No. 327, 1907, pp. 12-16). 
The general petrography of the rocks of the Knik region proves that the graywackes were derived largely from the destruction of a granitic rock, probably, as the inclusions in the greenstone tuff show, of quartz diorite character.

The various rock types-graywackes, greenstone tuffs, and rhyolite tuffs-are characterized by the presence of numerous small, angular slate fragments. Metamorphism has not proceeded far enough to mask the clastic origin of the typical members, nor to cause a marked development of new minerals.

The cleavage of these rocks is parallel to the bedding. The strike, which is $\mathrm{N} .60^{\circ} \mathrm{E}$. at the mouth of Knik River, gradually swings around to the north as the Knik is ascended and becomes N. $10^{\circ} \mathrm{E}$. at Knik Glacier. This change of strike in the strata coincides in a general way with the change in the axial trend of the Chugach Mountains, which in this region make a great bend to the south and continue into Kenai Peninsula as the Kenai Mountains. The dips are usually high, ranging from $40^{\circ}$ to $90^{\circ}$. Structurally the series presents a monoclinal succession of steeply dipping strata, which is undoubtedly due to repetition by close folding.

No fossils have yet been found in these rocks, so that only tentative conclusions regarding their age can be drawn. The slates and graywackes of the region under discussion are more highly metamorphosed than the shales and sandstones in the adjoining Matanuska region. As the latter are shown by their marine fauna to be in part Lower Jurassic, an age probably earlier than that is indicated for the slates and graywackes. From a similar line of evidence in the Kachemak Bay region Moffit ${ }^{1}$ has regarded the Sunrise "series" of Kenai Peninsula, with which these rocks are probably to be correlated, as of pre-Jurassic and probably Paleozoic age.

\section{LOWER JURASSIC ROCKS.}

The oldest rocks of this region of which the age has been definitely determined are Lower Jurassic volcanic beds. These occur in small areas within the area shown on the detailed geologic map (Pl. V, in pocket), and such occurrences are described fully below. They also cover large areas near the headwaters of Matanuska and Chickaloon rivers, where they were studied by Paige and Knopf, ${ }^{2}$ who referred them to the lower Middle Jurassic. The following paragraphs are abstracted from their description of these rocks:

The Lower Jurassic rocks comprise andesitic greenstones, quartz porphyries, and tuffaceous sandstones. The greenstones constitute

${ }^{1}$ Moffit, F. H., Gold fields of the Turnagain Arm region: Bull. U. S. Geol. Survey No. 277, 1906, p. 19.

2 Paige, Sidney, and Knopf, Adolph, Geologic reconnaissance in the Matanuska and Talkeetna basins, Alaska: Bull. U. S. Geol. Survey No. 327, 1907, pp. 16-17.

$9949^{\circ}-$ Bull. $500-12-2$ 
the most characteristic member and attain a wide distribution, especially in the interior of the Talkeetna Mountains.

The great bulk of the greenstones is largely in the form of stratified breccias in which angular fragments of dark-blue porphyritic rock, varying in size from pieces of microscopic dimensions to blocks several feet in diameter, are inclosed in a matrix of green color. This contrast of colors, which serves to emphasize the breccia character of the rock, is due to the fact that the matrix is abundantly changed into the green mineral chlorite, whereas the large angular fragments, being of a dense, fine-grained texture, have in places withstood alteration more thoroughly. With the breccias are intercalated sheets of amygdaloids, porphyries, and flow breccias. In many places the amygdaloids are studded with numerous large amygdules of chilcedony, quartz, calcite, chlorite, or zeolite.

A prominent feature of the greenstones is the great amount of shattering and slickensiding which they exhibit. Where this internal movement has been of a more regular character a rude schistosity has been impressed on them. Extensive pyritization of a diffused character was noted at several localities, but a thin irregular seaming with calcite appears to be the most usual form of mineralization.

Petrographically the greenstones are prevailingly andesitic and more or less completely chloritized. Examples more basic than andesite appear to be rare and were noted only on Boulder Creek about 7 miles from its mouth, where greenstones displaying columnar structure make up the north wall of the valley. These prove to be diabase porphyries.

Here and there the thickness of the greenstones exceeds 1,000 feet. The tuffs locally contain fragments of lignite, and at the east end of Sheep Mountain, in the upper Matanuska Valley, they carry marine shells in a fine state of preservation.

Various rhyolites and dacites, including their tuffs, are associated with the greenstones. These rocks are widely distributed in the interior of the Talkeetna Mountains. The rhyolites are generally flinty looking rocks containing glassy phenocrysts, but also include some distinctly flow-banded phases. Devitrification is common in the rhyolites. Some of the dacites resemble the rhyolites in appearance, but others possess a greenstone habit. These acidic lavas appear to have been erupted either during or soon after the period of the andesitic extrusions, as they contain included fragments of microlitic andesite.

During the extravasation of the rhyolites conditions were not uniform over the province. While lavas were accumulating in some portions of the region sedimentation was progressing in others. On the divide between Hicks and Boulder creeks a white stratum 20 feet thick is prominent. It proves to be a feldspathic sandstone, 
with some irregular thin white bands, about a quarter of an inch thick, scattered through it. The microscope shows that these bands are composed of microspherulitic particles and fragments of devitrified rhyolite, with fine flow structure, indicating that showers of rhyolitic material were prevalent during this portion of the Lower Jurassic epoch.

\section{GRANITIC ROCKS.}

Granitic rocks of granite, quartz diorite, and quartz monzonite habit and for the most part of moderately coarse granitoid texture, though locally foliated, occupy most of the mountain province north of Matanuska River and west of Chickaloon River. These rocks are thus geographically restricted save for a small mass on Sheep Mountain which has been regarded by Paige and Knopf ${ }^{1}$ as equivalent to the granitic rocks here discussed. Much of the rugged interior of the Talkeetna Mountains remains unexplored, but such evidence as is available indicates that the great central area consists largely of granitic rocks. The morainal material brought down by the glaciers from the remote recesses of the range and the gravels of the streams heading in the mountainous interior consist prevailingly of granitic material.

A considerable variety of rock types is found, but quartz diorites appear to predominate. A quartz diorite north of Moose Creek carries the dark minerals hornblende and biotite and is associated with a quartz diorite gneiss rich in hornblende. This gneiss extends also eastward to and along Granite Creek and is doubtless a cataclastic phase of the massive quartz diorite. Along the middle course of Chickaloon River quartz-augite diorite is present, but toward the headwaters it gives place to a muscovite granite. On the upper Talkeetna gneisses again appear, but along the lower course are exposed more quartz diorites. On the western flank of the Talkeetna Mountains granitic rocks outcrop in great abundance almost continuously from Talkeetna River to Willow Creek and again as a narrow band forming the southern boundary of the area of crystalline mica schist. Near Sheep Creek some uralitic gabbro is found. In the vicinity of Kashwitna River is a light-colored quartzose type, which proves to be a quartz monzonite.

The quartz diorites on the south side of Knik Arm are probably to be correlated with those making up the main mass of the Talkeetna Mountains. Similarly a small isolated boss of epidotized quartz diorite a few miles east of the mouth of Caribou Creek appears to belong to the same general mass.

1 Paige, Sidney, and Knopf, Adolph, Geologic reconnaissance in the Matanuska and Talkeetna basins, Alaska: Bull. U. S. Geol. Survey No. 327, 1907, p. 20. 
MIDDLE AND UPPER JURASSIC ROCKS.

The Middle and Upper Jurassic rocks of the Matanuska Valley were not recognized within the area here described in detail, but they have a considerable thickness and wide distribution farther east. They contain faunas which seem to represent those of all the Middle and Upper Jurassic formations present on Cook Inlet, although the beds containing the several faunas have not been separated in areal mapping. The following description of these beds is compiled from the report by Paige and Knopf. ${ }^{1}$

In the region east of Chickaloon River the Lower Jurassic volcanic rocks (lower Middle Jurassic of the report cited above) are overlain with apparent conformity by a series of sandstones and shales. Some finely flow-banded volcanic rocks, now devitrified, are in places associated with the sediments, proving that eruptive activity had not entirely ceased during their deposition. This series, by its dominantly sedimentary character, can be readily distinguished from the underlying meta-andesite.

The sandstones are usually feldspathic and under the microscope show numerous small fragments of microlitic andesite no larger than the feldspar or quartz grains. The shales locally carry numerous limestone nodules. At several localities these shales and sandstones are intensely shattered and crushed. This is especially notable in the gorge of Billy Creek. In this vicinity also occur several conglomerates not found elsewhere in the series.

In general the sandstones and shales are barren of fossils, though belemnites are rather common. The following species, however, were found and were submitted to T. W. Stanton, who reported as follows: ${ }^{2}$

6 A. K. 88A. Caribou Creek, tributary to Matanuska River:

Inoceramus cf. lucifer Eichwald.

Pleuromya.

Pleurotomaria.

Phylloceras.

Stephanoceras.

Oppelia?

6 A. K. 88B. Same locality as preceding, but found in float bowlder in stream bed:

Inoceramus.

Natica.

Phylloceras.

Stephanoceras.

Sonninia? (two species).

Belemnites.

The two lots are evidently from the same horizon and nearly all the species occur in the lower part ${ }^{3}$ of the Enochkin at Snug Harbor.

I Paige, Sidney, and Knopf, $\Lambda$ dolph, Geologic reconnaissance in the Matanuska and Talkeetna basins, Alaska: Bull. U. S. Geol. Survey No. 327, 1907, pp. 17-23.

2 Idem, p. 19.

${ }^{3}$ The lower part of the Enochkin formation is now known as the Tuxedni sandstone. (See Bull.

U. S. Geol. Survey No. 485, 1912, pp. 59-64.) 
The Upper Jurassic rocks consist largely of blue shales, locally carrying fossiliferous limestone nodules. With the shales are associated sandstones, conglomerates, and some tuffs and arkoses. Strata of this age have a wide distribution east of Chickaloon River, but were not observed in the Talkeetna Mountains.

The sandstones of this series are usually ordinary yellow sandstones, which in places are conspicuous on account of the multitudes of Aucella contained in them, this fossil making up as much as half of the rock. In some places the sandstones have a light-gray color, due to the fact that such beds are highly feldspathic and contain much finely comminuted black mica, locally with an abundance of small bits of carbonaceous material.

On Billy Creek a number of interstratified tuff beds from 1 to 4 feet thick occur near the top of the series, a few hundred feet beneath the base of the Cretaceous. These tuffs differ greatly in appearance from the older Jurassic tuffs. Higher in the series arkoses closely simulating granites in appearance are interstratified with the sandstones. The arkose appears to have been derived principally from the destruction of a volcanic land mass, but some of its material was possibly brought from a monzonite area, as indicated by the presence in it of fragments of monzonite. Under the microscope the feldspars of these arkoses by their alteration contrast strongly with the clear, glassy feldspars of the somewhat older crystal tuffs already described.

A notable accumulation of conglomerate, stretching over several square miles, occurs in the headwater region of Susitna River near Nelchina River, where extensive glaciation has produced deep troughs that expose splendid sections of it. Perpendicular cirque walls reveal a thickness of not less than 1,100 feet. Here and there thin layers of sandstone show that the conglomerate is lying in horizontal attitude. It is almost exclusively composed of large, well-rounded bowlders of augite andesite and quartz monzonite embedded in a tuffaceous matrix. At the upper horizons the bowlders of andesite preponderate. The bowlders of the conglomerate are ellipsoidal in shape, and many of them are as much as 2 feet in diameter. The conglomerate is lithified firmly enough to form large bowlders in the present stream wash. Sheets of lava are locally intercalated in the conglomerate.

Along Nelchina River, immediately below the junction of the north and south forks, the stream bluffs reveal an interdigitation of lenses of sandstone, shale, and coarse conglomerate. The sandstones show cross-bedding and contain remains of Aucella.

The thickness of the Middle and Upper Jurassic rocks is not definitely known. It certainly exceeds 2,000 feet, including a known thickness of 1,100 feet of conglomerate. 
The unconformity between the Upper and the Lower Jurassic records an important event in the dynamic history of the area. Below this break in stratigraphic sequence the rocks are shattered and broken and in many places are rudely schistose, and the andesites have assumed a greenstone habit and in several places have been extensively pyritized and veined by quartz and calcite seams. Above the unconformity the strata lie in comparatively undisturbed attitudes and the intercalated andesites are fairly fresh and unaltered, differing in this respect but slightly from the Tertiary volcanic rocks of the region.

The age of these strata has been determined from the following invertebrates, identified by T. W. Stanton:

Lot 6 A. K. 156. Headwaters of Nelchina River of Copper River drainage:

Cadoceras sp. Many immature specimens.

Belemnites. Fragments.

The horizon is that of the Cadoceras zone,${ }^{1}$ which forms the upper third of the Enochkin formation.

Lot 6 A. K. 185. Nelchina River:

Pleuromya.

Cadoceras? Fragmentary imprint doubtfully referred to the genus.

Belemnites.

The horizon is probably in the upper part ${ }^{1}$ of the Enochkin formation.

Lot 6 A. K. 136. Billy Creek:

Aucella cf. bronni Rouiller.

The same species occurs in similar rock in the Naknek formation of Kamishak Bay.

The fossils indicate faunas of both late Middle Jurassic and Upper Jurassic age. It is interesting to note that the Upper Jurassic rocks of this region, which are faunally allied to those of the Naknek formation on the west coast of Cook Inlet, show a certain lithologic similarity in the presence of interstratified tuffs and arkose. ${ }^{2}$ Furthermore, an accumulation very similar to the remarkable andesitegranite conglomerate occurring on the headwaters of Susitna River is found at the base of the Naknek formation. ${ }^{3}$

\section{LOWER CRETACEOUS ROCKS.}

The Lower Cretaceous is represented by a single formation-a massively bedded limestone, 300 feet thick, which overlies the Upper Jurassic strata conformably on the headwaters of Billy Creek and Nelchina River, where it outcrops in prominent gray cliffs encircling the hilltops. It is also represented by the probably equivalent limestone north of Castle Mountain described below (pp. 32-33). The limestone at the headwaters of Billy Creek and Nelchina River is

\footnotetext{
1 The Cadoceras zone, constituting the upper part of the Enochkin formation, is now known as the Chinitna shale. (See Bull. U. S. Geol. Survey No. 485, 1912, pp. 65-68.)

${ }^{2}$ Stanton, T. W., and Martin, G. C., Mesozoic section on Cook Inlet: Bull. Geol. Soc. America, vol. 16, 1905 , p. 402.

${ }^{3}$ Martin, r. C., The petroleum fields of the Pacific coast of Alaska: Bull. U. S. Geol. Survey No. 250, 1905, p. 44.
} 
described by Paige and Knopf ${ }^{1}$ as white and of very finely saccharoidal texture. On fresh fracture it emits a strong fetid odor. It is readily soluble in cold hydrochloric acid and evolves an abundance of unpleasant hydrocarbon gases. Qualitative tests show the presence of not more than a trace of magnesia. Under the microscope the detrital organic origin of this limestone is readily apparent. It is composed largely of irregular granules of dirty-looking calcite, but with these are associated numerous prismatic sections referable to organic fragments. Rhombohedral cleavage is here and there finely developed, but the characteristic calcite twinning is notably absent. Some of the carbonate is still in the aragonite form, as is indicated by negative biaxial interference figures. Accessory constituents are limpid plagioclase, quartz with hairlike rutile, hornblende, and, more rarely, augite and apatite. The incomplete conversion of the carbonate to the stable modification and the absence of twin lamellation in the calcite indicate the essentially static conditions in which the limestone has remained since its formation.

The age determination of this Cretaceous formation is based on the presence of Aucella crassicollis Keyserling, obtained by Mendenhall ${ }^{2}$ from a conglomeratic sandstone at the base of the limestone. This conglomerate may indicate a time break between the Lower Cretaceous rocks and the Upper Jurassic strata that lie in apparently conformable attitude beneath them.

\section{UPPER CRETACEOUS ROCKS.}

The Upper Cretaceous rocks of the Matanuska Valley consist of about 4,500 feet of shale and sandstone, deposited, so far as known, wholly in marine waters. These deposits have been recognized in this part of Alaska only within the area described below in detail. The character and age of these beds were not recognized in the earlier investigations, and they are included in the areas mapped as Tertiary by Martin ${ }^{3}$ and by Paige and Knopf. ${ }^{4}$ It is highly probable that they extend east of the area shown on the detailed map (Pl. V, in pocket) and include beds represented on the general geologic map (Pl. III, in pocket) as Tertiary or as Upper and Middle Jurassic.

\footnotetext{
1 Paige, Sidney, and Knopf, Adolph, Geologic reconnaissance in the Matanuska and Talkeetna basins, Alaska: Bull. U. S. Geol. Survey No. 327, 1907, p. 24.

2 Mendenhall, W. C., A reconnaissance from Resurrection Bay to Tanana River, Alaska, in 1898: Twentieth Ann. Rept. U. S. Geol. Survey, pt. 7, 1900, p. 309.

3 Martin, G. C., A reconnaissance of the Matanuska coal field, Alaska, in 1905: Bull. U. S. Geol. Survey No. 289,1906, Pl. III.

${ }_{4}$ Paige, Sidney, and Knopf, Adolph, Geologic reconnaissance in the Matanuska and Talkeetna basins, Alaska: Bull. U. S. Geol. Survey No. 327, 1907, Pl. II.
} 
The Tertiary sedimentary rocks of the Matanuska Valley have in the earlier descriptions been treated as a stratigraphic unit and are thus represented on the general geologic map (Pl. III, in pocket). It has been found possible and desirable, in the area mapped in detail, to subdivide these rocks. Three Tertiary formations are consequently represented on the detailed geologic map ( $\mathrm{Pl} . \mathrm{V}$, in pocket) and will be described below. These formations are, in descending order, the Eska conglomerate, the Chickaloon formation, and an unnamed formation consisting of arkose, conglomerate, and shale. The local Tertiary rocks include also volcanic beds and intrusive masses.

The subdivisions of the Tertiary have been carried only over the area of the detailed geologic map (Pl. V), so it is necessary to map the Tertiary as a unit in the remainder of the valley. (See Pl. III.) The Tertiary rocks along Chickaloon River north of the end of Castle Mountain are chiefly conglomerate and are believed to include both the Eska conglomerate and the conglomerates of the basal Tertiary formation. The area mapped as Tertiary east of Chickaloon River is probably occupied chiefly by the Chickaloon formation.

Overlying the older Tertiary rocks unconformably is a series of nearly horizontal basalt flows, which, with their intercalated pyroclastic rocks, attain a thickness of 1,000 feet. They were seen within the area mapped in detail only on Castle Mountain, but they are extensively distributed throughout the Talkeetna Mountains and compose many of the peaks and summits of the region. They weather in tints of red and break down in characteristic erosional forms which lend a picturesque castellated appearance to the mountain crest lines.

The basalt flows with their interbedded tuffs and breccias present a stratified appearance. The surface upon which these volcanic rocks were accumulated appears to have been one of gentle relief, cut across the upturned edges of the older rocks. The discordance between the nearly horizontal basalts and the underlying strata varies from $10^{\circ}$ to $90^{\circ}$. About the headwaters of Chickaloon River this basalt surface slopes gently northward. East of Chickaloon River its altitude is about 5,000 feet. It is somewhat broken by faults.

The basalts display a wide variation in habit and texture. Highly glassy types, amygdaloids, porphyries, and dolerites are variously represented. They belong to the acidic end of the basalt family and are in general nonolivinitic.

The basalts overlie the Eska conglomerate unconformably and are probably of late Tertiary and possibly of Pliocene age. Their petrog- 
raphy suggests that they are the effusive equivalents of the diabase dikes and sills that are so common in the Tertiary of the Matanuska Valley. These volcanic rocks of the Talkeetna Mountains can be correlated with the great Tertiary volcanic series of the upper Nizina Valley, described by Schrader and Spencer, and with an important volcanic series on Nabesna River, described by Brooks. Both these series are said to comprise andesites, rhyolites, and pyroclastic rocks and both were deposited unconformably upon a general uniform surface. The volcanic rocks of the Talkeetna region, however, show a greater petrographic uniformity and consist exclusively of basalts and their fragmental accumulations. In this respect they show a closer resemblance to the late Tertiary lavas of the Alaska Peninsula, and the Aleutian Islands, which have been described by Spurr ${ }^{1}$ as andesitic basalts.

\section{QUATERNARY DEPOSITS.}

The Quaternary deposits include morainic accumulations, terrace gravels, and the alluvial deposits on the present flood plains. The glacial deposits and terrace gravels are especially well developed throughout the lower lands west of Chickaloon River, where the former glaciers and the glacial streams were depositing. Farther east, where the glaciers were eroding more actively and where they stood above the level of the waters in which the terraces were formed, the gravel cover is thin and local.

The deposits in the valley of the Matanuska are described in detail in the following pages. The Quaternary deposits on the lowlands bordering Knik Arm are of somewhat different character.

The bluffs on the shore of Knik Arm in the vicinity of Knik are composed entirely of Quaternary deposits. Those at Knik are made up of stratified sand and gravel, but an exposure seen from the steamer several miles below (near or just above Goose Bay) is apparently unstratified and is probably till.

The bluffs from Knik to Cottonwood are all of stratified sand and gravel, as at Knik. They rise to a general elevation of about 100 feet above high tide. The upper limit is a well-defined level behind which the surface is hummocky. At Cottonwood the general upper surface level is well developed at 57 feet above extreme high tide, there being also a distinct bench at 16 feet. Exposures of the material are poor, but the good drainage and the presence of only wellwashed material in the slides indicates that the gravel is stratified and not a strict morainic deposit.

The trail from Cottonwood to Grassy Ridge passes through a hummocky but fairly well terraced country whose surface gradually

\footnotetext{
1 Spurr, J. E., A reconnaissance in southwestern Alaska in 1898: Twentieth Ann. Rept. U. S. Geol. Survey, pt. 7, 1900, p. 234.
} 
rises toward Grassy Ridge. The topographic forms appear to include a variety of features of glacial origin, such as eskers, possibly drumlins, and irregular glacial dumps, as well as benches which may be products purely of glacial outwash but which, presumably, include also marine terraces (chiefly constructional). The rise toward Grassy Ridge is accomplished chiefly by steep ascents from bench to bench. Grassy Ridge is a long, narrow, steep-sided, sinuous gravel ridge on the north shore of Finger Lake. North of it is a creek flowing westward. The crest of the ridge undulates in elevation, the average height being about 36 feet above Finger Lake and 47 feet above the creek. ${ }^{1}$ The ridge is probably an esker, though possibly a piece of lateral moraine. The trail traverses other similar ridges west of this point.

The trail from Grassy Ridge to Moose Creek passes over a country similar to that from Cottonwood to Grassy Ridge until it crosses the second creek, beyond which it rises by a gentle slope toward the bank of Matanuska River. It comes out on top of the bank overlooking the Matanuska about 3 miles below Moose Creek, where it is on stratified gravel at an elevation of about 300 or 400 feet above the river. From this point it runs near the edge of the bank, going over flat benches, all of which are apparently at about the same elevation, and in and out of shallow draws and undrained hollows. The trail descends into the valley of Moose Creek over several well-defined benches, which are described more fully below.

\section{DETAILED DESCRIPTION OF THE ROCKS OF THE LOWER MATANUSKA VALLEY.}

\section{GRANITIC AND GNEISSIC ROCKS.}

\section{AREAL DISTRIBUTION.}

Granitic and gneissic rocks occupy two areas along the northern border of the region covered by the detailed map (Pl. V, in pocket). One of these areas extends from the valley of Moose Creek to the headwaters of Young Creek and northward into the Talkeetna Mountains for an unknown distance. It probably includes the entire upper parts of the valleys of Moose and Granite creeks, for the beds of these streams at the edge of the region mapped on Plate $\mathrm{V}$ are made up entirely of bowlders of granite, and no sedimentary rocks could be seen in the mountains at their heads. The other area extends from the divide between Young and Granite creeks to the divide between Kings and Chickaloon rivers and up Kings River probably to its headwaters, although sedimentary rocks also are known to be present here. 
The older crystalline rocks within the area represented on the detailed map comprise granites and quartz diorites, many of which are more or less gneissoid, and also probably smaller but undifferentiated masses of thoroughly gneissic and fine-grained schistose rocks. The granite rocks are for the most part light colored, moderately coarse grained, and of a granitic texture and contain macroscopic quartz, feldspar, hornblende, and in some places also biotite.

Gneissic banded rocks of moderately fine grain, composed of quartz, feldspar, and hornblende, are present on Moose Creek. Intrusive into these rocks are fine-grained whitish granitic rocks of alaskitic habit, composed of quartz, feldspar, and very little biotite. Coarsegrained, slightly gneissoid granites are also present in this locality. The gneissoid texture of these rocks is due to a rough parallelism of constituent minerals which, under the microscope, are seen to be crushed, granulated, and bent and to have undergone considerable alteration to secondary minerals. These granites of cataclastic gneissoid habit are composed of primary quartz, alkalic feldspars, hornblende, and biotite, and accessory magnetite and apatite. The secondary minerals are chiefly quartz, iron oxides, chlorite, and epidote.

On Eska Creek there are both distinctly banded gneissic rock and merely gneissoid granite, similar to the rocks on Moose Creek. No banded gneissic rocks were seen east of Eska Creek, but most of the granites along the southern borders of their areas are gneissoid.

In the neighborhood of Kings River there are granites of medium grain consisting of quartz, acidic plagioclase (and orthoclase?), biotite, hornblende, and magnetite. There is some variety in these rocks due to reciprocal relations in the amounts of feldspar and ferromagnesian minerals, especially the hornblende. The rocks containing more of the ferromagnesian minerals are usually finer grained and much darker in color. Small patches or "inclusions" of such rock within the lighter, coarser varieties are very common.

Along the fault zone which marks their south boundary the older crystalline rocks are, at several places, as on Eska Creek and on the ridge north of Castle Mountain, severely crushed and altered, with the development of epidote, chlorite, calcite, and other minerals, so that their original characters are very obscure. In some of these deformed rocks there is very profound veining by irregular and small to minute seams of calcite and quartz.

\section{AGE AND RELATIONS.}

The granitic rocks and the highly metamorphosed gneissic rocks which occur in association with them constitute a complex which could not be divided in the small amount of investigation which 
was made on the margin of their area. The gneissic rocks are believed to be part of a possibly extensive ancient series of metamorphic rocks having close relations with the mica schists on Willow Creek. (See p. 15.)

The gneissoid granites, which are very certainly younger than the rocks just mentioned, may be the representatives of a granite mass which was slightly metamorphosed and intruded by later nongneissoid granites. On the other hand, they may very probably be but the locally altered representatives of one general mass, of which the nongneissoid granites are another facies. There is little in favor of either of these alternatives, unless it be in the evidence of two widely separated periods of granitic intrusion, found in the facts that Jurassic rocks are intruded by granites (see below) and that the pre-Jurassic (see p. 17) graywacke on Knik Arm is composed of detritus from the destruction of a granite mass. ${ }^{1}$

The arkosic rocks, which are believed to be at the local base of the Tertiary, rest upon an even surface of granite, contain pebbles identical in lithologic character with the underlying granite, and are believed to have been laid down upon an eroded granite land surface (See Pl. VI, A.) The general southern boundary of the granite areas is in most places along faults by which the granites are brought into contact with both the Tertiary and the Upper Cretaceous rocks. (See Pls. VI, $B$; VII, $A$; and XIV, $A$ and $B$, p. 72.) The granite is in contact with the Lower Jurassic volcanic rocks and with the probably Lower Cretaceous limestone in the ridge north of the west end of Castle Mountain. The nature of the contact at this point is not as clear as could be wished. Near the contact the granite shows evidence of having been severely crushed, and there is probably some faulting at this locality. The actual contact could not be observed at close range, so it is not known definitely whether the granite is intrusive into either or both of the Mesozoic formations. The contact, as seen in cliffs which were inaccessible, looked very much as if it were intrusive. On the other hand, the granite is not noticeably finer grained near the contact than away from it, nor could it be seen that the limestone or the Lower Jurassic volcanic rocks were more altered near the edge of the granite mass.

The date of intrusion of the granitic mass of the Talkeetna Mountains is assigned to the Middle Jurassic by Paige and Knopf ${ }^{2}$ on the ground that the Upper Jurassic rocks on the headwaters of the Matanuska contain bowlders of granite identical in character with that of the mountains, and the Lower Jurassic volcanic rocks on Sheep Mountain are cut by a small mass of granite. There is a

\footnotetext{
1 Paige, Sidney, and Knopf, Adolph, Geologic reconnaissance in the Matanuska and Talkeetna basins, Alaska: Bull. U. S. Geol. Survey No. 327, 1907, pp. 14-15.

'Idem, p. 21.
} 


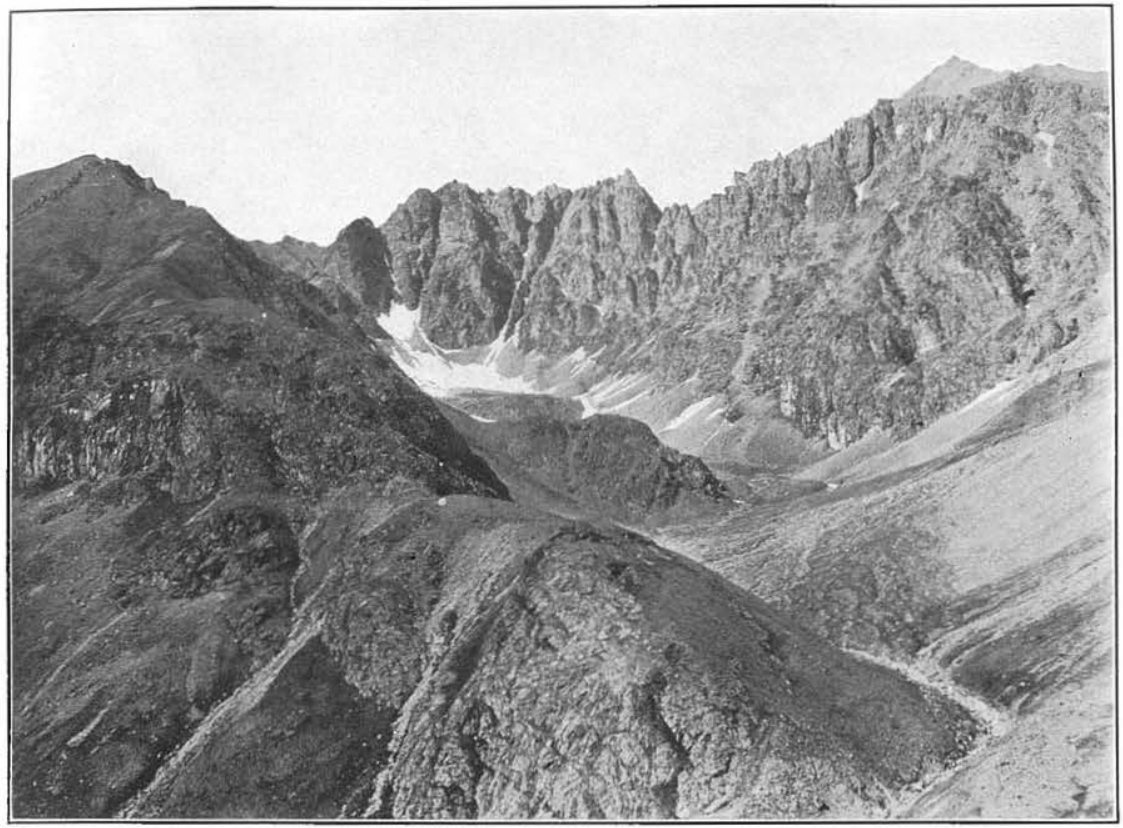

A. GRANITE AND TERTIARY ARKOSE IN GULCH ON THE WEST SIDE OF SHEEP VALLEY.

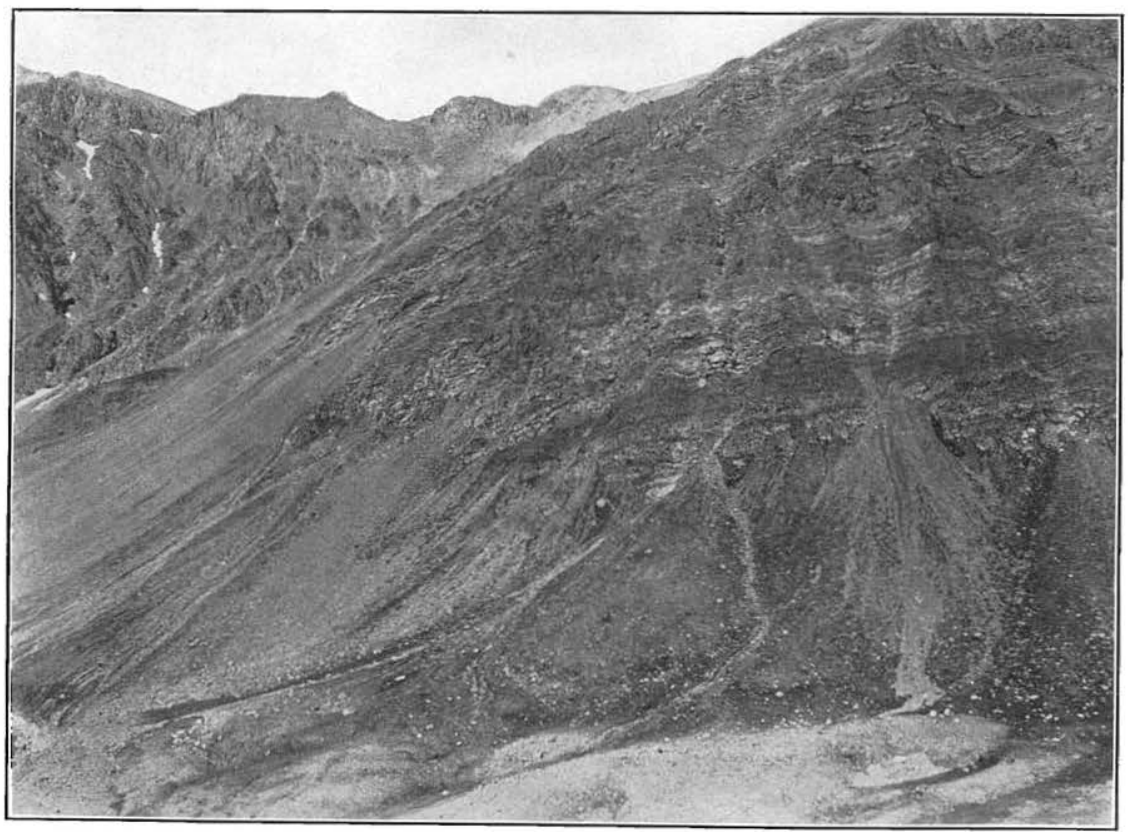

B. GRANITE AND TERTIARY ARKOSE IN THE WEST WALL OF SHEEP VALLEY. 



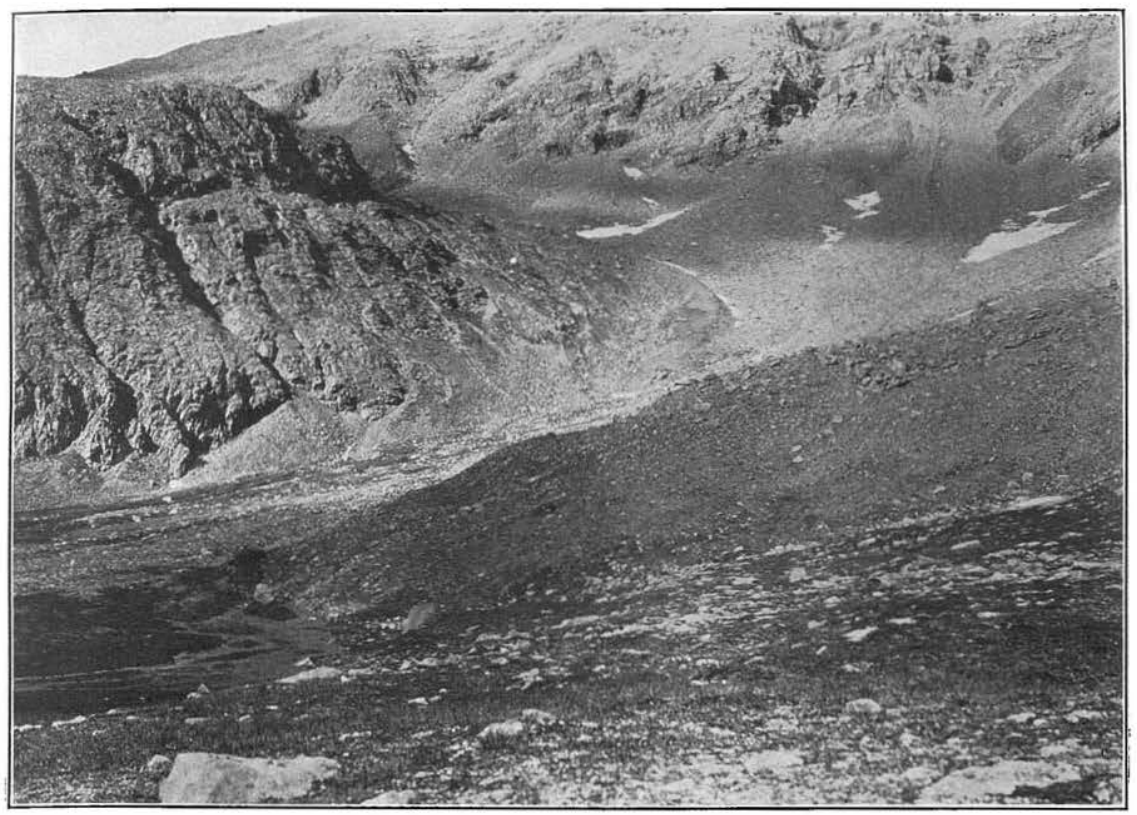

a. Granite overlain by arkose at the head of SHEep Valley.

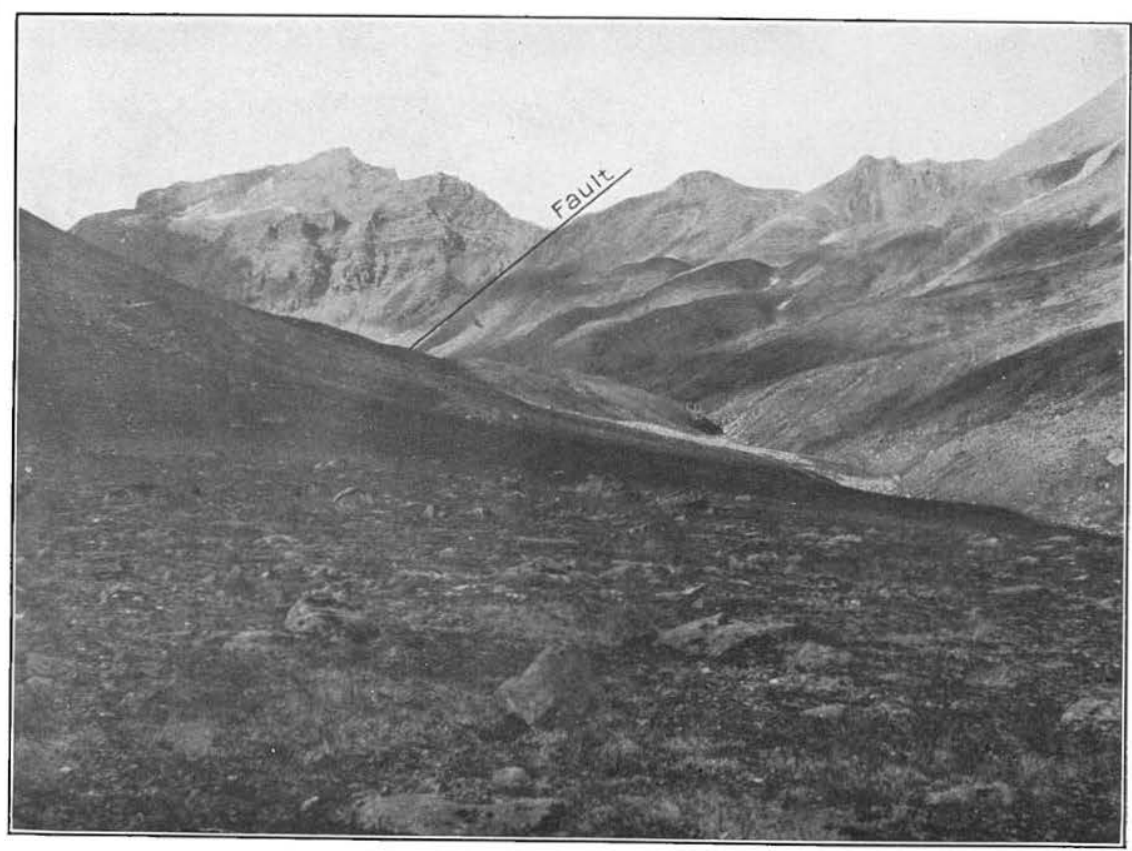

3. SHEeP VALLey FROM a POINT NEAR ITS LOWER END.

Showing the gently dipping arkose represented in Plate VII, A, overthrust on closely folded arkose beds. 

weak point in this evidence, as the small granite mass on Sheep Mountain is 28 miles distant from the main granite mass of the Talkeetna Mountains and may or may not be contemporaneous with it. The evidence is, however, very suggestive and is in harmony with the apparently intrusive character of the contact of the granite with the Lower Jurassic volcanic rocks north of Castle Mountain and with what is known of the date of intrusion of similar granite masses not only in Alaska but throughout the American Pacific coastal mountains.

\section{LOWER JURASSIC ROCKS.}

VOLCANIC BRECCIA, AGGLOMERATE, AND TUFF.

AREAL DISTRIBUTION.

The Lower Jurassic rocks occupy two areas in the east end of the district here under discussion. They occur in a belt north of Castle Mountain, extending from Kings River to and probably beyond Chickaloon River, and in another belt south of and parallel to the Matanuska, extending from Carbon Creek eastward for an undetermined distance. They also occupy large areas in the upper Matanuska Valley and in the region north of it, as will be noted below.

\section{LITHOLOGIC CHARACTER.}

These rocks are well exposed on the creek tributary to Chickaloon River from the west a mile above the Government Bridge. The beds here exposed consist of lavas, agglomerates, and breccias of considerable diversity of character interbedded with tuffs which are waterlaid and well bedded and which carry abundant marine fossils of the species listed below. Beds of the same character were seen on Doone Creek immediately behind the east end of Castle Mountain, where also fossils were obtained.

The exposures seen on the mountain north of the west end of Castle Mountain consist entirely of the more typical volcanic accumulations, without recognized bedded rocks, and reveal more alteration of the rocks than was seen at the exposures first described. The rocks at this point are rather of the greenstone type.

Coal Creek, at a point about $1 \frac{3}{4}$ miles above its mouth, passes through a narrow gorge both walls of which are made up of green tuff with angular inclusions and rolled pebbles of red, purple, and green igneous rocks. These rocks have a structure dipping northward at an angle of $10^{\circ}$ or $15^{\circ}$, which may be bedding.

Just below this gorge, on the east bank of the creek, northwarddipping graywacke or fine-grained tuff is exposed in a contact of undetermined relationship with the coarser tuff seen in the gorge. These 
beds seem to grade upward into shales which are harder than the typical shales of the Tertiary and approach in character the Cretaceous shale on Kings River. Interbedded with the shale is a 4 -foot bed of conglomerate of different character from any seen in the Tertiary.

Above the gorge, on the east bank of the creek and well exposed at the north end of the high cliffs shown on the map near the edge of the sheet, are more massive fine-grained rocks, which are believed to be also tuffaceous.

The Mesozoic volcanic rocks north of Doone Creek include a number of lavas, tuffs; and breccias which constitute part of the bedded series of volcanic rocks described by Paige and Knopf ${ }^{1}$ and which have a more varied and extensive development outside the limits of the area here described in detail. North of Doone Creek the following rocks were seen: Felsites of creamy white and drab color, the former containing phenocrysts of small white feldspar and black decomposed biotite (?); brownish-green narrow-banded tuffs of fine angular, clastic texture; dark fine-grained fragmental rocks studded with small white feldspar crystals; banded fossiliferous tuffs composed of angular bits of feldspar and hornblende or other dark mineral or fragments of dark rock; stratified breccias in which angular fragments of porphyritic or felsitic rocks are embedded in a matrix of only slightly different appearance, accentuated on weathered surfaces; and black aphanitic vesicular basalts. All these rocks are much weathered. The prevalent green color indicates general development of secondary minerals and decomposition products. Some of these rocks are severely crushed and shattered and in them epidotization and chloritization are particularly pronounced. These rocks are intricately interlaced with small quartz and calcite seams. Paige and Knopf found among these rocks mainly andesites, dacites, and rhyolites and their tuffaceous equivalents.

FAUNA.

Marine fossils were collected from the tuff beds exposed on Doone Creek and on the creek north of it. These have been identified by T. W. Stanton as follows:

6693. Creek entering Chickaloon River from west 1 mile above Government Bridge.

Elevation, 2,200 feet.

Rhynchonella sp.

Pecten sp. a. Smooth form.

Pecten sp. b. Strongly ribbed Vola type.

Pecten sp. c. Large, flat, coarse-ribbed form.

1 Paige, Sidney, and Knopf, Adolph, Geologic reconnaissance in the Matanuska and Talkeetna basins Alaska: Bull. U. S. Geol. Survey No. 327, 1907, pp. 16-19. 
6697. Doone Creek, at mouth of gulch, 3,950-foot point, traverse of August 30. Float. Rhynchonella sp.

Pecten sp. a.

Pecten sp. b.

Pecten sp. d.

Trigonia? sp.

Cardinia? sp.

Deroceras? sp.

Atgoceras? sp.

6706. Creek entering Chickaloon River from west 1 mile above Government Bridge. Elevation, 2,000 feet.

Pecten sp. b.

Deroceras? sp.

6707. Creek entering Chickaloon River from west 1 mile above Government Bridge. Float from base of falls.

Rhynchonella sp.

Gryphæa? sp.

Ostrea sp.

Pecten sp.

Probably Jurassic.

6708. Creek entering Chickaloon River from west 1 mile above Government Bridge.

Float above falls.

Pecten sp.

Several undetermined small pelecypods.

Possibly Jurassic.

6709. On same creek as 6,708 at elevation 2,200 feet. From talus.

Jurassic. Cardinia? sp.

\section{AGE AND CORRELATION.}

The following statement concerning the age and correlation of the fauna found in these beds has been submitted by T. W. Stanton:

The lots numbered $6693,6697,6706-6709$ are referred to the Jurassic and are probably Lower Jurassic, though the paleontologic evidence for the latter reference is not so full as is desirable. The fossils are almost certainly from the same beds from which Mr. Knopf collected his lot No. 201, on the head of Matanuska River, in 1906. Mr. Knopf's collection was at that time doubtfully referred to the "Enochkin formation," but I am now inclined to consider the beds from which he collected equivalent to the supposed Lower Jurassic near Seldovia and to regard them as Lower Jurassic. It is true that not more than two or three species have been found common to the different localities from which these fossils have been collected, but the general character of the fauna in each case is suggestive of Lower Jurassic, and it is probable that more systematic collecting would prove that the different lots really belong to a single fauna.

The fossils collected by Knopf and referred to by Stanton in the preceding paragraph have been described as follows: ${ }^{1}$

1 Paige, Sidney, and Knopf, Adolph, Geologic reconnaissance in the Matanuska and Talkeetna basins, Alaska: Bull. U. S. Geol. Survey No. 327, 1907, p. 18. 
The fossils found in tuffs associated with the greenstones were submitted to T. W Stanton, who reports as follows:

6 A. K. 201. Fossiliferous tuffs, associated with lavas and coarse pyroclastics, from the head of Matanuska River:

Rhynchonella.

Lima.

Pecten. Smooth species.

Pecten. Species of Vola type.

Trigonia.

Astarte?

Protocardia.

Pleuromya.

Sonninia?

The Jurassic age of this lot is clearly shown by the form of the Trigonia and of the ammonite (Sonninia?). The general aspect of the fauna is that of the lower part of the Enochkin, ${ }^{1}$ though it may be somewhat older than the fauna in lots $88 \mathrm{~A}$ and 88B. With the exception of the Vola-like species of Pecten there is nothing in it to suggest the Lower Jurassic fauna of Seldovia.

The assignment of this fauna to the Lower Jurassic rather than to the Middle Jurassic is in harmony with the fact that the Middle Jurassic of Cook Inlet ${ }^{2}$ is not known to contain volcanic beds, while the Lower Jurassic of Cook Inlet ${ }^{3}$ does contain volcanic beds of lithologic character strikingly similar to that of the beds here under discussion.

LOWER CRETACEOUS (?) ROCKS.

LIMESTONE.

AREAL DISTRIBUTION.

Limestone occurs north of Castle Mountain in a belt within which there is one large area and at least three smaller ones. The best exposures are on the ridge north of the west end of Castle Mountain. Other exposures were seen at the head of Doone Creek and on the next creek north of it.

LITHOLOGIC CHARACTER.

The limestone, as seen on the ridge north of the west end of Castle Mountain, is blue and gray to white, of fine to medium grain (crystallinity), much shattered and full of minute calcite veins, and as seen on top of the ridge well bedded (in beds 6 inches to several feet thick) without decided change in lithology from bed to bed. The westernmost exposure on top of the ridge, a small, isolated outcrop at an elevation of $4,700 \pm$ feet, contains beds which are decidedly cherty.

1 The lower part of the Enochkin formation is now known as the Tuxedni sandstone.

2 Martin, G. C., and Katz, F. J., A geologic reconnaissance of the Iliamna region: Bull. U. S. Geol. Survey No. 485 , 1912 , pp. $59-68$.

3 Moffit, F. H., Gold fields of the Turnagain Arm region: Bull. U. S. Geol. Survey No. 277, 1906, pp 20-22. 
The limestone exposed on the creek north of Doone Creek is at the bend about a mile above the mouth of the creek. The exposure is in the form of a vertical comb of crystalline cherty limestone at least 50 feet thick. The trend of the vertical mass, which is possibly the strike of the limestone, is $\mathrm{N} .45^{\circ} \mathrm{E}$. No bedding was recognized. The rocks on the east side are concealed by a moraine. West of the limestone outcrop is a mass of sticky reddish clay.

The grain of this limestone ranges from subcrystalline to that of loaf sugar. It is mostly white, though numerous pinkish masses were seen. The pink color is largely, but not altogether, on the surface. Masses of chert and cherty limestone are abundant. No clearly bedded masses of chert were recognized. The appearance of the rock suggests that whatever bedding it once possessed is now entirely destroyed by the shattering and recrystallization which it has undergone.

STRATIGRAPHIC RELATIONS.

The limestone on the erest of the ridge north of Castle Mountain lies in a closely compressed overturned syncline and rests upon somewhat altered volcanic rocks which are considered to be the same as the Lower Jurassic volcanics with which they are areally continuous. (See Pl. XV, p. 72.) An exposure on the west end of this ridge shows the rocks in direct contact and small pebble-like fragments of the greenstone embedded in the lower 2 inches of the limestone. These fragments give evidence that the limestone overlies the greenstone unconformably.

AGE AND CORRELATION.

No fossils have been found in the limestone of the district here described, so the determination of its age depends on the local stratigraphic evidence and on correlation with the rocks of neighboring regions.

It has already been shown that the limestone rests unconformably upon Lower Jurassic rocks. The Middle and Upper Jurassic rocks of the upper part of the Matanuska Valley show a complete sequence of several thousand feet of strata in which limestones are absent. The Upper Jurassic is overlain, on Billy Creek and Nelchina River, by a massively bedded limestone at least 300 feet thick, at the base of which ${ }^{1}$ are Lower Cretaceous fossils. Although there are differences in the features of the two limestones, they are such as might be explained by the fact that the two occurrences are 25 miles apart and in structurally different areas. These limestones are here provisionally correlated and referred to the Lower Cretaceous.

1 Mendenhall, W. C., A reconnaissance from Resurrection Bay to the Tanana River, Alaska, in 1898: Twentieth Ann. Rept. U. S. Geol. Survey, pt. 7, 1900, pp. 308-309. Paige, Sidney, and Knopf, Adolph, Geologic reconnaissance in the Matanuska and Talkeetna basins, Alaska: Bull. U.S. Geol. Survey No. 327, 1907, p. 24.

9949 - Bull. $500-12-3$ 


\section{UPPER CRETACEOUS ROCKS.}

AREAL DISTRIBUTION.

The Upper Cretaceous rocks cover a large area in the central part of the region here described. They include all the exposures of hard rock in the banks of Matanuska River from a point $2 \frac{1}{2}$ miles below Chickaloon River to Moose Creek and occupy all of the valley of Granite Creek 6 miles above its mouth, much of the upper part of the valley of Young Creek, the west side of the valley of Kings River from 6 to 10 miles above its mouth, the low hills between Kings River and the Matanuska, and a small area in the valley of Carbon Creek.

\section{LITHOLOGIC CHARACTER.}

The rocks consist of shale and sandstone, having an aggregate thickness of at least 4,000 feet, of which the lower half is practically all shale and the upper half consists of alternating beds of sandstone and shale, the former predominating. Conglomerate is present, but not in thick or abundant beds. The most complete observed section is in the gorge of Granite Creek and is recorded below. Other good sections are exposed on Kings River between the main trail and the coal camp and in the cliffs of Matanuska River. Many of these cliffs are not accessible for close study except at a very low stage of the water.

Section in Upper Cretaceous rocks on Granite Creek, beginning at lower end of canyon, $1 \frac{3}{4}$ miles from the mouth of the creek.

Black shale at base, overlain by thin-bedded gray sandstone, some of which is very fine and has contorted laminæ, and gray or drabgray shales (beds are interleaved lenses rarely more than 6

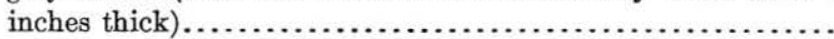

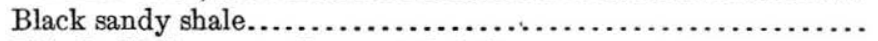

Thin-bedded gray sandstone and shale.....................

Black nodular shale.....................................

Sandstone, mainly thick beds about 5 feet thick, with thin interbedded shales. .................................. $\quad 30$

Interbedded black shale and thin gray sandstone and shale..... 50

Massive sandstone, feldspathic and micaceous................ 20

Interbedded gray shale, gray sandstone, and black shale.......... 40

Sandstone...................................... 12

Alternating beds, 1 to 8 feet thick, of gray sandy shale and black shale.......................................... 250

Similar beds increasingly to dominantly sandy and light gray.... $\quad 80$

Dark-colored sandstone and sandy shale.................... $\quad 75$

Light-gray sandstone including several thick, massive beds and some very thin shales (in east bank; estimated thickness).....

Dark shale in beds alternating with thin sandstones and lightcolored shale. 
Sandstone, heavy bedded at the top but dominantly thin bedded (beds 1 to 2 feet and less than 1 foot), with many beds of very thin shaly sandstone having contorted laminæ; also a few thin shale beds and an increasing number of dark shales in the lower part. ...........................................

Exposures interrupted and inaccessible for 1,500 feet along the creek, equivalent to an estimated stratigraphic interval of.....

Dark bluish-black sandy shales outcropping for 200 feet in a direction about $\mathrm{N}$. $17^{\circ} \mathrm{E}$.; strike N. $40^{\circ} \mathrm{E}$.; dip, $60^{\circ} \mathrm{SE}$; computed thickness............................................

Exposure interrupted and inaccessible for 800 feet along the creek, equivalent to an estimated stratigraphic interval of............

Hard dark blue-black shale, ${ }^{1}$ outcropping for about 200 feet in a direction N. $17^{\circ}$ E.; strike, N. $28^{\circ}$ E.; dip, $60^{\circ}$ to $65^{\circ} \mathrm{SE}$.; computed thickness.....................................

Exposure interrupted and inaccessible for about 200 feet along the creek, equivalent to an estimated stratigraphic interval of.....

Hard dark blue-black shale ${ }^{1}$ outcropping for 400 feet along the creek in a direction N. $17^{\circ}$ E.; strike, N. $47^{\circ}$ E.; dip, $50^{\circ} \mathrm{SE}$.; computed thickness......................................

Exposure interrupted and inaccessible for 100 feet along the creek, equivalent to an estimated stratigraphic interval of............

Hard dark blue-black shale, ${ }^{1}$ outcropping for about 1,000 feet along the creek; estimated thickness................... $400 \pm$

No exposure for 7,500 feet.

Several small outcrops through 1,200 feet along the east bank of the creek in a northerly direction; strike, N. $23^{\circ}$ E.; dip, $49^{\circ} \mathrm{SE}$.; computed thickness.................................. $350 \pm$

The section on Granite Creek was measured in the gorge that begins $1 \frac{3}{4}$ miles above its mouth and extends northward for 2 miles; in this distance exposures are almost continuous on one or the other bank, and in some places on both banks of the stream. It is assumed, in accepting this section and thickness, that there is no repetition of the beds by faulting. The exposures are not of such a character as to make this an absolutely safe assumption, although the absence of observed faults, or of beds which seem to be repeated, and the fact that the ridge on the east of the gorge presents an unbroken dip slope, suggest that the section is an uninterrupted and unrepeated monoclinal succession of beds.

The rocks exposed in the gorge of Granite Creek are southeastwarddipping sandy shales and flaggy sandstones. Inoceramus and other Upper Cretaceous fossils were collected from the shales of the lower part of the section, in the positions indicated. The sandstones, which predominate higher in the section, yielded no fossils except a fragmentary nuculoid form. No plant fossils were seen. 
These rocks differ lithologically from the Tertiary rocks of the region in that the shales are considerably more indurated than the Tertiary shales. The Upper Cretaceous shales are prevailingly black-markedly so in the lower half of the section; the Tertiary shales are prevailingly gray, being black only where they are highly carbonaceous, and there containing many thin coal streaks. The Upper Cretaceous shales break on clearly defined bedding and joint planes; the Tertiary shales break into shapeless masses. The former weather into masses of undecomposed shale pieces, on which bedding and either joint planes or conchoidal fractures determine the sharp edges of the fragments. The latter break down into small, nonplaty, shapeless masses and dust. The Upper Cretaceous sandstones are darker, less inclined to be arkosic, more indurated (that is, in general, although some beds in the Tertiary are very hard), and more evenly bedded. Very fine grained laminated micaceous and flaggy sandstones are characteristic of the Upper Cretaceous rocks. The thin laminæ of these fine-grained sandstones are irregularly contorted. Other criteria for distinguishing these rocks from the Tertiary rocks are the absence of coal and the rarity of fossil sticks and of leaves, the presence of fucoidal markings in sandstones and of marine fossils in the shales, the presence of thin beds and nodules of very hard reddish-weathering sandstone with curved bedding, the greater amount of shattering, and the greater abundance of thin calcite veins. Beds of finely conglomeratic sandstone with scattered subrounded black pebbles from the size of bird shot to that of a pea are present in and are characteristic of the older rocks.

The features described below, shown at an exposure of bluish-black shale in the gorge of Kings River 8,000 feet above the bridge on the main trail, are characteristic of the dark shales that form the lower part of the Upper Cretaceous section. Although the rock looks slaty on large exposure, when struck or when a mass falls it breaks into irregular lathlike pieces several inches long, an inch or two in width, and half an inch to an inch thick, owing to a very uneven jointing perpendicular to the bedding. Perpendicular both to this jointing and to the bedding is the major jointing, which is very well defined. The shale contains numerous hard nodules from half an inch to 10 inches in diameter. These appear to consist of the same material as the shale. In places they weather out, leaving an iron stain. No leaves or carbonaceous material were seen.

FAUNA AND FLORA.

These rocks possess a distinctive marine invertebrate fauna which has been recognized by the presence of abundant Inoceramus at many localities. The fossils are more abundant in the shales which 
make up the bulk of the lower part of the formation, although Inocera mus was seen in the higher sandy beds.

The following lists of fossils were submitted by T. W. Stanton:

6689. Granite Creek, west bank, between elevations of 1,000 and 1,050 feet:

Rhynchonella? sp.

Inoceramus sp. Very large compressed form which has been collected on Alaska Peninsula north of Aievak or Douglas village.

Inoceramus sp. Related to I. labiatus.

Upper Cretaceous.

6690. North bank of Matanuska River, at lower end of lower gorge 1.1 miles north of Moose Creek:

Inoceramus sp.

Upper Cretaceous.

6691. East bank of Kings River at Coal Camp:

Inoceramus sp. Fragment of large, flat species.

Upper Cretaceous.

6692. Pass between Kings River and Young Creek:

Rhynchonella? sp.

Inoceramus sp.

Upper Cretaceous.

6694. Kings River, east bank, three-fourths of a mile below U. S. L. M. No. 1.

Ostrea sp.

Inoceramus sp. Large, compressed species, as in lot 6689.

Diplomoceras notabile Whiteaves?? Fragments of a large specimen.

Upper Cretaceous.

6695. North bank of Matanuska River, at upper end of lower gorge at mouth of Eska Creek:

Inoceramus sp. Fragment.

Probably Upper Cretaceous.

6696. Creek entering Granite Creek from west 5 miles above main trail, about half a mile west of and 470 feet in altitude vertically above Granite Creek.

Inoceramus sp. Probably young of large species in lot 6689.

Phylloceras sp.

Nemodon? sp.

Amberleya sp.

Pachydiscus sp.

Desmoceras sugata Forbes?

Desmoceras? sp.

Anisoceras? sp.

This collection is clearly of Upper Cretaceous age and belongs to the general IndoPacific fauna, which is well developed in India, Japan, Sakhalin, Vancouver, and California.

6699. 3,350-foot knob 1 mile north of east end of Chain Lakes:

Fragment of an undetermined echinoid.

Horizon not determinable.

6700. East bank of Kings River 0.35 mile above mouth:

Inoceramus sp.

Probably Upper Cretaceous.

6701. North bank of Matanuska River $3 \frac{1}{2}$ miles east of mouth of Kings River:

Inoceramus sp.

Probably Upper Cretaceous. 
6702. East bank of Kings River one-fourth of a mile above its mouth:

Inoceramus sp.

Probably Upper Cretaceous.

6703. Kings River, east bank, 3,850 feet below mouth of Little Kings.

Inoceramus sp.

Probably Upper Cretaceous.

6704. Carbon Creek 3,875 feet above mouth:

Inoceramus sp.

Probably Upper Cretaceous.

6705. Young Creek, in float:

Inoceramus sp.

Probably Upper Cretaceous.

Some fossils of more or less problematic character were seen in the sandstones on Kings River, on Coal Creek, and elsewhere, in associro tion with large shells and fragments of Inoceramus. The following report on specimens from Kings River has been submitted by Arthur Hollick.

5893, 5894. "Kings River, at Coal Camp:'”

Remains and markings of uncertain identity. One specimen appears to be

a Spirophyton. Others may be worm tracks or burrows.

Age not determined.

Fossil plants of species unlike those in the local Tertiary formations were collected from beds which lie a short distance below the contact with the diorite mass west of Kings River and which werel regarded as occurring in the upper sandy part of this formation. The following report on this collection was made by Arthur Hollick:

5898. "Locality (34) at south of pond on top of mountain between Kings River and Young Creek, $1 \frac{1}{8}$ miles N. $10^{\circ}$ W. from Kings River Bridge:'

Equisetum arcticum Heer? Specimens very fragmentary. Some pieces might equally well be referred to E. robustum Newb.

Glyptostrobus ungeri Heer? Fràgmentary remains of a heterophyllous conifer, some of which might equally well be referred to Juniperus tertiaria Heer.

Nyassa arctica Heer.

Aristolochia sp. This is in great abundance and is very variable in form. Some specimens are hardly to be distinguished from certain forms of Populus arctica Heer.

This is a meager and more or less unsatisfactory collection. The general facies is different, however, from that of any other collection from the Matanuska field. Age, basal Eocene.

AGE AND CORRELATION.

The marine fauna contained in these rocks shows that they are of Upper Cretaceous age. T. W. Stanton has submitted the following statement regarding the age and relation of this fauna:

Of the lots referred to the Upper Cretaceous those numbered 6689, 6694, and 6696 are certainly of that age and belong to the Upper Cretaceous fauna which has been recognized at several points on the Alaska Peninsula and is part of the general IndoPacific fauna found in the Chico formation of California, on Vancouver Island, in Japan, and in India. Most of the other lots in this collection, referred to the Creta- 
ceous, contain only fragmentary specimens of Inoceramus which are not sufficient in themselves for discrimination between Jurassic and Cretaceous, though it is probable that these fragments belong to the same species that occurs at other localities in the neighborhood where the Cretaceous age of the rocks is definitely determined.

The problematic fossils occur in immediate association with a large form of Inoceramus and are thus known to be Mesozoic, and as they are found above the horizons at which the more characteristic Upper Cretaceous fauna occurs, they are consequently Upper Cretaceous also. They are not sufficiently characteristic to yield of themselves independent evidence on the age of the rocks.

The fossil plants of lot 5898 were collected from beds which are stratigraphically above the highest beds containing observed marine Cretaceous fauna but which are lithologically identical and apparently stratigraphically conformable with them and are lithologically unlike any of the known Tertiary beds of this region. These beds are considerably more indurated than any of the local Tertiary rocks except those which have been involved in the intense deformation in the mountain region north of the Matanuska Valley. The field relations consequently indicate, though they do not prove, that this flora is older than the Tertiary floras described below and suggest that it belongs in the Upper Cretaceous. The flora is somewhat different in character from the known Tertiary floras but is, nevertheless, more like them than it is like any known Mesozoic floras.

\section{TERTIARY ROCKS.}

The Tertiary rocks consist of three sedimentary formations overlain unconformably by basaltic lavas and tuffs and intruded by many dikes, sills, and stocks.

ARKose, CONGLOMERATE, AND SHALE.

AREAL DISTRIBUTION.

The rocks grouped under the above heading are found in a belt extending along the northern border of the Matanuska Valley from the Little Susitna to Chickaloon River. They are known to occupy a considerable area in the Talkeetna Mountains between Granite Creek and Kings River and probably occur at other points within the mountains. They have not been recognized south of the great fault, which, throughout the area represented on the detailed map (Pl. V, in pocket), marks the northern edge of the Matanuska Valley proper.

LITHOLOGIC CHARACTER.

The arkose, conglomerate, and shale are highly indurated, in this respect, as in other lithologic characteristics, differing from the other Tertiary rocks, described on pages 42-54. 
The rocks exposed in the ridge north of Moose Creek are principally arkose, with a few beds of shale. The arkose is fine grained and conglomeratic in places, but the conglomeratic feature nowhere predominates. The rocks have a dark-brown to gray color and contain all the essential constituents of granite. Quartz, feldspar, hornblende, biotite, and chlorite can be easily recognized. Locally the feldspan is much kaolinized. The chlorite gives the whole rock in places a greenish tinge. Much of the arkose somewhat resembles an igneous rock. Some of it is so much like granite in appearance that its sedimentary character is recognizable only by a few rounded pebbles and carbonized plant remains. On the other hand, the arkose grades into conglomerate so that no definite line can be drawn between them.

The exposures on the northern slope of the ridge (see Pl. VIII) show a thickness of over 1,500 feet of bedded rocks with no faulting. The outcrops on the crest of the ridge consist in some places of crossbedded granitic arkose and in others of fine-grained conglomeratic arkose with small amounts of sandy shales and micaceous sandstones.

The conglomerates seem to be best developed north of Castle Mountain, where they are faulted against the Eska conglomerate, giving an excellent opportunity for the recognition of the essential lithologic characteristics of each formation. The following is a description of beds exposed in the creek entering Chickaloon River from the west a mile above the Government bridge. This creek emerges at an elevation of about 1,500 feet from a gorge with overhanging walls of sandstone and conglomerate. The conglomerate is the fine-pebble, well-indurated kind seen in Doone Creek north of Castle Mountain. The pebbles are mostly under 1 inch, though a few are 2 or 3 inches in greatest dimension, and are mostly of quartz and dark quartzite, the latter most abundant. They are not well rounded and are set in a matrix of fine conglomerate or coarse grit. The sandstone is more indurated than that of the Chickaloon formation and resembles more closely some of the sandstones of the Upper Cretaceous.

Conglomerate extends up the creek to an elevation of 1,660 feet, giving a thickness of several hundred feet. It becomes coarser upstream, containing numerous pebbles 3 to 5 inches in length. Some 4-inch pebbles of shale were seen. At no point do these beds resemble those of the Eska conglomerate.

At elevation 1,660 feet there is a sharp (fault?) contact of conglomerate with shale which resembles that of the Chickaloon formation, but is somewhat more indurated. The bedding of both rocks and the contact plane are vertical. The contact strikes N. $55^{\circ} \mathrm{E}$. The shale is of no great thickness and is succeeded a short distance upstream by conglomerate. 


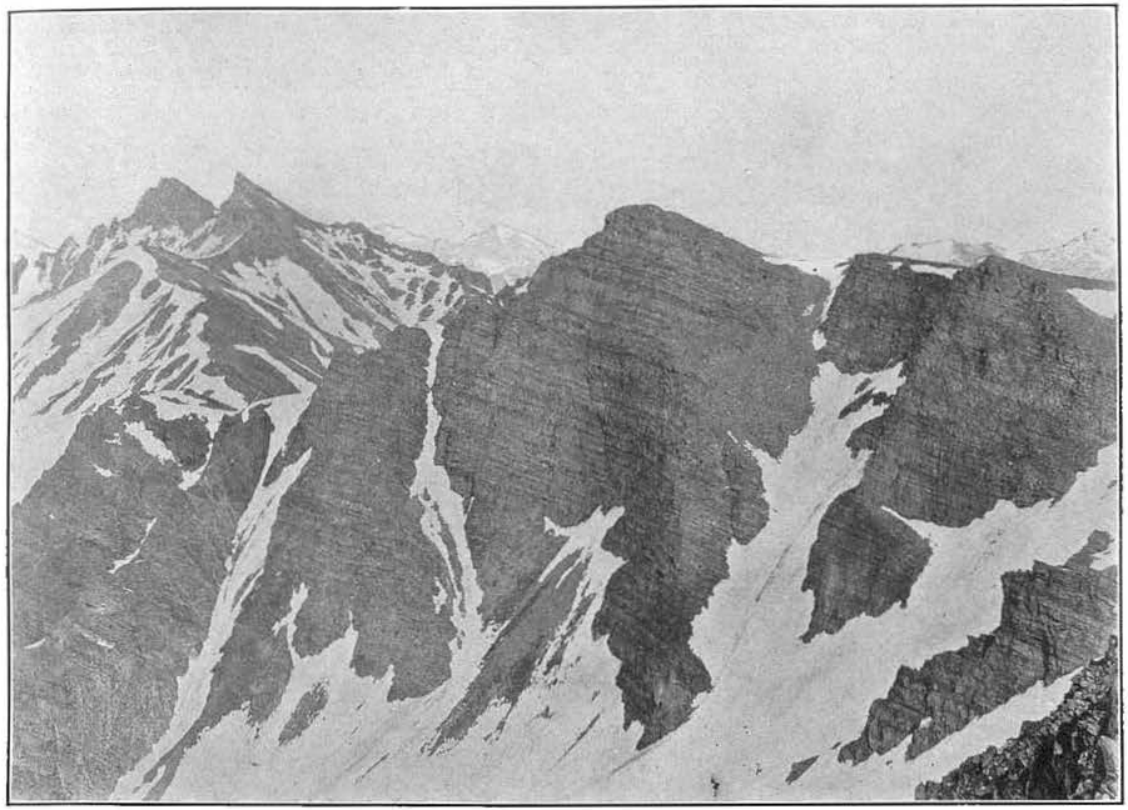

A. EXPOSURE OF ARKOSE IN CLIFFS ON NORTH SLOPE OF RIDGE NORTH OF MOOSE CREEK.

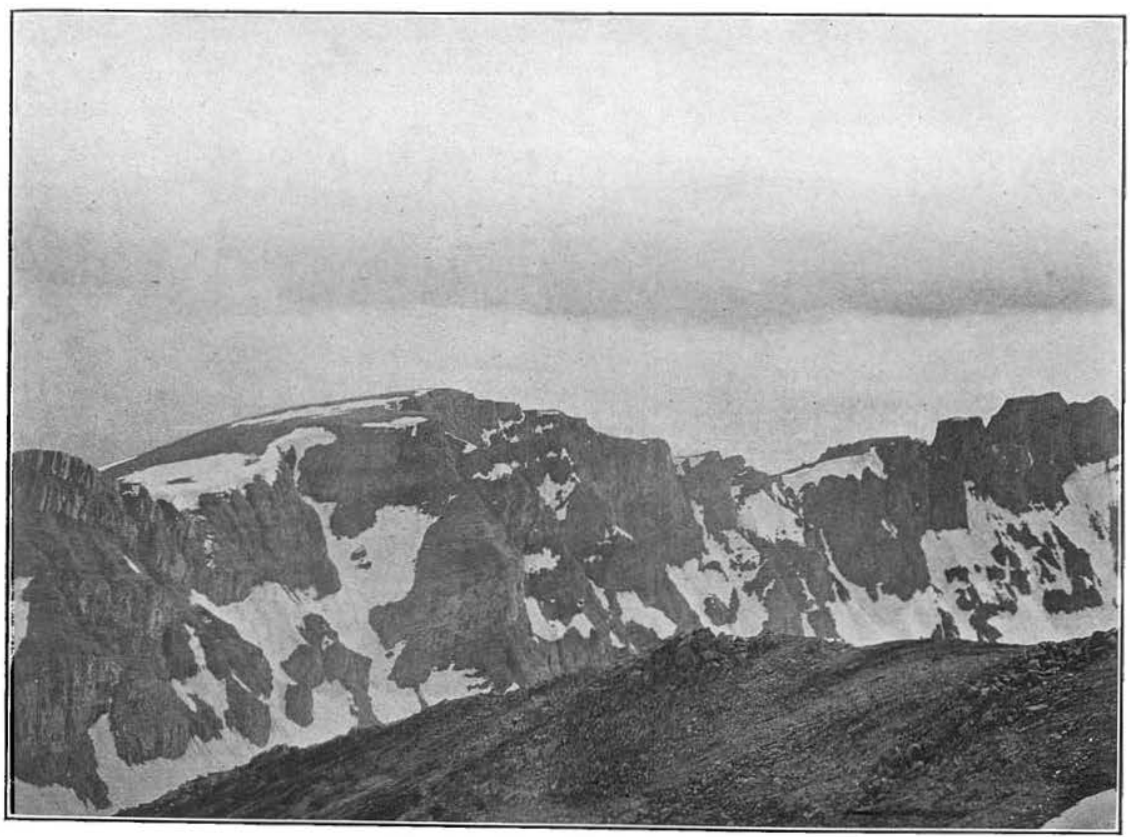

B. GENTLY DIPPING ARKOSE IN WEST END OF RIDGE NORTH OF MOOSE CREEK.

The crest of the ridge shows remnants of old smooth topography into which glacial erosion has cut cirques 

Conglomerate, sandstone, and shale in rapid alternation extend from elevation 1,660 feet to 1,780 feet. The conglomerate predominates in the exposures, but the three rocks are probably of about equal bulk.

At elevation 1,780 feet is an exposure of much broken sandy shale, some beds of which are very carbonaceous. One or two beds, now reduced to a crushed mass, are so black as to suggest that the beds were coal or coaly. These are less than 1 foot thick.

\section{STRATIGRAPHIC RELATIONS.}

The arkosic rocks rest upon an approximately even surface of granite, this contact being at all observed points parallel to the bedding of the sediments. The contact in the mountain west of Kings River at the edge of the area shown on the detailed map (Pl. $\mathrm{V}$, in pocket) is at an elevation of about 4,500 feet and, like the bedding of the arkose at this point, is practically horizontal. The rocks are more steeply folded in the valley west of this mountain and in the ridge north of Young Creek, but the dips, which are dominantly northwest, are essentially parallel to the basal contact with the granite. The same condition exists in the ridge north of Wishbone Hill except that the bedding and the contact with the granite are both steeply inclined toward the south. Similar conditions apparently exist on the ridge north of Moose Creek. (See Pls. VII, $B$, p. 28 ; XIV, $A$, p. 72 ; and XV, p. 72.)

The contact of the base of the arkosic rocks with the granite is a sedimentary contact. The evidence for this statement consists in the uniform parallelism of the contact with the bedding, in the absence of any recognized marginal facies in the granite or of any apophyses from it, in the presence in the arkose of detritus similar to the granite in composition, and in the absence of any contact metamorphism in the sedimentary rocks. The lack of evidence that there are granites anywhere in Alaska which are young as this arkose is corroborative evidence that this granite is not intrusive into the arkose.

The arkosic rocks are also in contact with the other Tertiary rocks and with the Cretaceous and Jurassic sedimentary rocks. These contacts, so far as observed, are faults. (See Pls. XV and XVI, p. 72.) The absence of any observed sedimentary contacts of the arkosic rocks with the Upper Cretaceous rocks which should underlie them or with the other Tertiary formations which, it is believed, should overlie them leaves the exact stratigraphic position of these beds more or less in doubt. These rocks have been separated from the other Tertiary sedimentary beds described below on the basis of their predominantly arkosic character, greater degree of induration, and absence of coal. There is little doubt that these rocks are for. the 
most part low in the local Tertiary sequence and include the basal beds, although possibly the assemblage represented on the man includes in part the marginal facies of some beds higher in the Teris tiary, as well as higher beds not necessarily marginal but now occurs ring in structural zones in which they have been deformed to a degree not permitting their separation from the basal or marginal deposits, The thickness of these beds exceeds 2,000 feet.

FLORA.

Fossil plants are abundant in many of the shaly beds of this group of rocks, but are in general not well preserved on account of the intense deformation which the rocks have undergone. The following species were identified by Arthur Hollick from material collected by the writers in 1910 :

5900. Sheep Valley, $6 \frac{1}{2}$ miles N. $7^{\circ}$ E. of mouth of Kings River, elevation 4,400 feet;

Populus arctica Heer.

Quercus platania Heer.

Age, "Arctic Miocene" (Eocene).

Paige and Knopf collected the following species, which were identified by F. H. Knowlton, in 1906:

Arkose Ridge, north of Moose Creek:

Taxodium distichum miocenum Heer.

Taxodium tinajorum Heer.

Populus sp.?

Ficus? grönlandica? Heer.

Paliurus colombi Heer.

Fruits, cf. Leguminosites sp.

Age, apparently Kenai.

\section{CHICKALOON FORMATION.}

AREAL DISTRIBUTION.

The Chickaloon formation covers the greater part of the valley of Chickaloon River, south of Castle Mountain, or south of a point about 5 miles in an air line above the mouth of that stream. This ares extends west to Kings River, the same formation occupying the eastern bank of Kings River between points about 6 miles and 8 miles above its mouth. It also extends south of Matanuska River from a point $2 \frac{1}{2}$ miles below the mouth of Chickaloon River at least to a point 4 miles above its mouth, and it extends east of the area whtch was mapped for an unknown distance, possibly as far as the mouth of Hicks Creek.

The same formation occurs in three small detached areas in the valley of Kings River, one of which is on the banks of Kings River from 5 miles to $6 \frac{1}{3}$ miles above its mouth and the other two are on 
Young Creek near its mouth and in the upper part of its valley. The outcrops in the areas near the mouth of Young Creek and on Kings River 6 miles above its mouth are possibly parts of the same mass, the apparent discontinuity being due to the presence of a gravel sheet, which conceals the underlying rocks except in cliffs.

The Chickaloon formation is also exposed in the banks of Eska Creek, on Moose Creek, and on the north bank of Matanuska River for about a mile below the mouth of Moose Creek. These exposures are probably all parts of one general body, much of which is covered by gravels.

\section{LITHOLOGIC CHARACTER.}

The Chickaloon formation consists of a rather monotonous succession of shales and sandstones. The shales, which predominate over the sandstones in aggregate thickness, are gray to drab, rather soft and inclined to disintegrate on exposure, poorly bedded, and without well-defined joint planes. Most of the beds are rather gritty and vary in grain along the bedding. They contain many nodules and lines of nodules of iron carbonate, some of which form fairly persistent beds. The sandstones are yellowish, rather soft, of diverse grain in the different beds and of varying grain in the same bed; and for the most part feldspathic; in general, the individual beds are not very persistent. The thickness of the formation is doubtful but appears to be at least 2,000 feet.

Fossil leaves are present in both the shales and the sandstones, and are especially abundant and well preserved in the beds carrying iron carbonate.

The coal beds are numerous. There is no evidence as to their exact position within the formation or as to the persistence of individual beds or groups of beds.

The sections given on the following pages are typical of the lithologic character, although none of them represent anything near the full thickness of the formation nor is their exact position within the formation known.

Section in the Chickaloon formation at the bend of Chickaloon River half a mile above Chickaloon coal camp.

Ft. in.

1. Gray shale with occasional concretions................. 16

2. Hard clay shale, nodular.............................. $2 \quad 6$

3. Fissile gray shale with iron balls.................. 16

4. Dark-gray limestone.............................. 1

5. Dark fissile shale.............................. $4 \quad 6$

6. Micaceous sandstone................................ $2 \quad 6$

7. Dark liver-colored fissile shale containing strata of iron con-

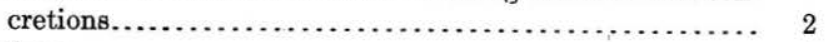

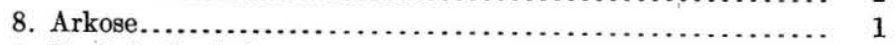

9. Dark fissile shale................................ 12

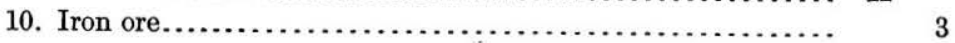


11. Black shale.

12. Carbonaceous shale and bone.

13. Black shale.

14. Dark fissile shale with many strata of ironstone nodules.... 33

15. Carbonaceous shale................................ 2

16. Dark shale with thin strata of ironstone balls............... 23

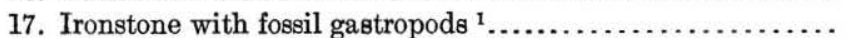

18. Dark shale with many streaks of iron ore.................. 6

19. Soft black carbonaceous shale........................ 6

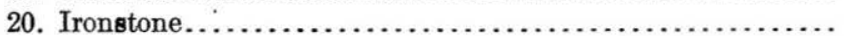

21. Dark fissile shale with bands of ironstone.............. 35

22. Massive sandstone................................. 10

23. Black shale ................................... 6

24. Coal, with some bone and shale ${ }^{2} \ldots \ldots \ldots \ldots \ldots \ldots \ldots . \ldots \ldots$

25. Shale and sandstone............................. 10

26. Coal, with some bone and shale................... $8 \quad 9$

27. Dark shale.................................. 6

28. Dark shale with coal streaks........................ 2

29. Shale with sandstone and ironstone bands............. 19

30. Sandstone with sandy shale bands.................... 9

31. Shale........................................ 1

32. Coal, impure, much distorted and changed by heat.... 5

33. Shale with iron bands.............................. 9

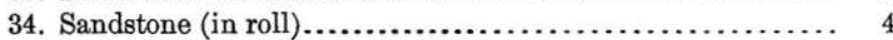

35. Shale........................................... 7

36. Diabase sill, with local occurrence of natural coke on top.. 11

37. Irregular mass of coal and carbonaceous matter much

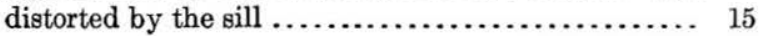

Section in the Chickaloon formation beginning at east end of the outcrop in the bluff at Chickaloon coal camp.

Coal bed.

$$
\begin{aligned}
& \text { Ft. in. } \\
& 15+
\end{aligned}
$$

Gray shales with ironstone bands and nodules; lower 6 feet thickly packed with large nodules..................... 21

Carbonaceous shale....................................... 196

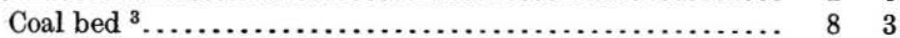

Shales and sandy shales with many sandstone lenses and ironstone nodules ${ }^{4}$

Gray shale....................................... $7 \quad 8$

Carbonaceous shale with thin coal streaks................. 9

Sandy shale and sandstone with ironstone................. $8 \quad 8 \quad 6$

Fissile carbonaceous shale.............................. 19

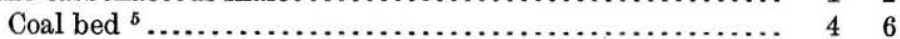

Shales with many ironstone bands....................... $21 \quad 6$

Coal, clean, bright ................................... 18

Shaly sandstone..................................... 15

Coal with shaly bands .............................. 12

\footnotetext{
1 Fossils in lots 3316 and 6698 (see p. 52) were collected from this bed.

2 This bed and the bed at the top of the following section are at about the same horizon and probably are the same bed.

${ }^{3}$ This is the lowest coal represented in section 9 (p. 79), at the entrance of tunnel A. It is also the lowest coal bed in section 13 , tunnel 2 (p. 80).

4 This is the lowest shale bed in section 11 (p. 80), at the entrance of tunnel B.

5 This is the lowest coal in section 15 (p. 80), near the entrance of tunnel 3.
} 
Largely concealed, chiefly shale ${ }^{1}$

Ft. in.

1010

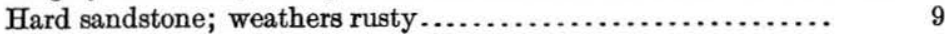

Gray shaly sandstone.................................. 16

Bluish nodular shale with sandy lenses and ironstone nodules. . $\begin{array}{lll}12 & 9\end{array}$

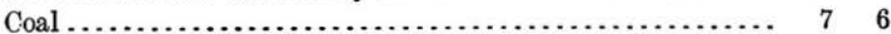

Coal and shale ................................... $4 \quad 4$

$\begin{array}{lll}\text { Black waxy shales with thin coaly streaks, sandy at top........ } & 2 & 9\end{array}$

Gray sandy shales ${ }^{2}$ (one-eighth inch coal streak near top)..... 10

(Continuity doubtful.)

Dirty coal and carbonaceous shale with thin coal lenses........

Gray sandy shales with many bands of ironstone nodules, grad-

ing laterally into massive gray sandstone............

Coal, varying greatly in character along strike and contain-

ing large silicified sticks. . . . . . . . . . . . . . . . . .

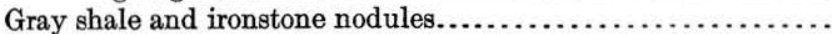

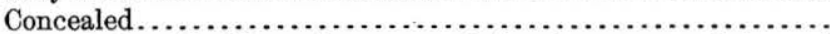

Gray shale with thin carbonaceous shales, ironstone nodules and

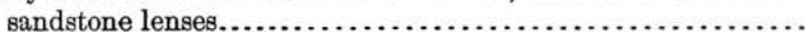

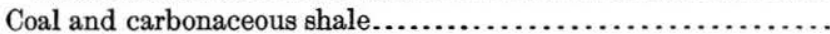

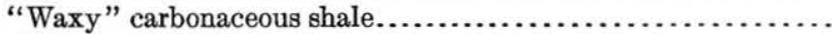

Gray shale with ironstone nodules.....................

Coal bed ${ }^{3}$

Nodular gray shale, ironstone concretions in band at base.....

Gray shale as above poorly exposed......................

Concealed but probably gray shale with ironstone and a little carbonaceous shale containing coal streaks...............

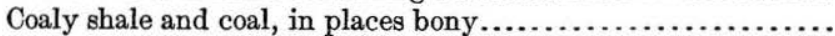

Gray shale with ironstone nodules and sandy lenses. ..........

Carbonaceous and sandy shales and sandstone, partly concealed.

Shale.

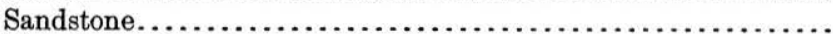

Thin beds of sandstone with 6 inches of ironstone. . . . . . . . .

Carbonaceous, fissile shale with small coal lenses, 2 inches or less

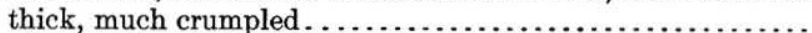

Sandy nodular shales with large sandstone lenses and large ironstone concretions.

Gray nodular shales and carbonaceous shales with short lenses of

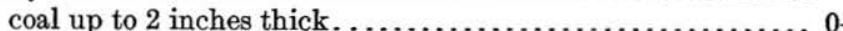

Gray nodular and sandy shales, fissile and carbonaceous at the top, grading laterally into and interleaved with shaly sandstone containing numerous ironstone nodules.

Dark-bluish nodular shale chiefly, with carbonaceous shale and thin coal lenses, sandstone lenses, and ironstone nodules.....

Bluish dark leaf-bearing shale with very thin coaly streaks and several ironstone bands laterally overlapping sandstone lens..

"Waxy" fissile carbonaceous shale.

Shaly sandstone and shales with ironstone nodules, varying rapidly in character laterally.

Fissile carbonaceous shales, with coaly streaks, gray sandy shales, and ironstone.

Nodular sandy shales with several bands of ironstone concretions.

Gray sandstone, grading laterally into sandy shales, and large ironstone nodules 
Sandy shales and ironstone nodules.

Sandy shales with small coal streaks and lensesand a few small ironstone nodules; carbonaceous shale at top................

Sandy shales and thin sandstone lenses....................

Gray speckled sandstone with carbonized plant remains and bits

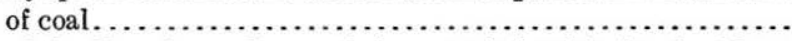

Dark leaf-bearing and gray shales containing thin bands of ironstone nodules and a lens of coked shaly coal at base.......... Diabase sill.

Gray shale.

Sill (probably not extensive). Below this sill the exposure is continued in the cliff along Chickaloon River but is more or less concealed by slide or is inaccessible.

Gray sandy shales and dark carbonaceous shales and thin sandstones containing a 15 -foot sandstone bed and several diabase sills; estimated thickness.

Heavy diabase sill.

Shales, dominantly gray and concretionary, with intercalated sandstone beds and lenses and ironstone concretions; computed thickness...................................

Diabase sill.

Gray sandy and concretionary shales with five or more thin ironstone bands and thin lenses of sandstone in lower part; computed thickness......................................

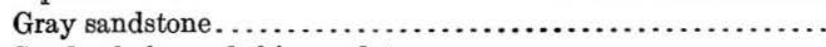

Sandy shales and thin sandstones....................... 28

Diabase sill.

Thin-bedded and slightly cross-bedded sandstone........... 13

Shale......................................... 1

Concealed.

Shale (including $5 \frac{1}{2}$-foot sill); estimated thickness.......... 90

Concealed.................................... 40

Dark-gray and brownish shales with ironstone nodules and in part sandy; computed thickness...................... 176

Concealed.

Gray thin cross-bedded sandstone and sandy concretionary shale. 20

Sill.

Dark-gray shale with ironstone band.................... 4

Concealed.

Sill.

A similar succession of beds is repeated through the remaining $1 \frac{1}{2}$ miles down Chickaloon River, but could not be measured or reliably estimated because of the folding of the beds and the recurring interruptions of the outcrop. The above section is over 1,200 feet thick, and in the lower $1 \frac{1}{2}$ miles of Chickaloon River and along Matanuska River below the Chickaloon there is perhaps as much more exposed.

On Boulder Creek from a point at about the east edge of the area shown on the detailed map down to a point half a mile above the mouth of the creek there is a nearly continuous exposure of the Chickaloon formation in which there is no sign of interruption or repeating of beds. Neither the top nor the base of the formation is 
exposed. The strike and dip are nearly uniform, averaging N. $76^{\circ}$ W., $34^{\circ} \mathrm{NE}$., through 6,400 feet in a direction N. $83^{\circ}$ E. From these figures the thickness of the section is estimated at 1,240 feet.

On a creek tributary to Chickaloon River opposite Boulder Creek, from a point about 8,000 feet above the mouth of the creek to a point about 2,000 feet farther upstream, is a continuous section approximately 1,060 feet thick. The lower half consists chiefly of lightcolored sandy shales; the upper half is made up principally of dark shales.with thin sandstone beds and many thicker beds of carbonaceous leaf-bearing shales which include numerous minute coal lenses. Several fossil logs and tree stumps, one of which is 20 feet long and stands normal to the bedding, were seen. Below this section the pxposures are interrupted and the structure is not uniform, but it is certain that there are at least 200 feet of lower beds into which wo or more considerable sill-like masses of gabbro are intruded. Lbove this section there are several hundred feet of sandstones, hales, etc., below the base of the Eska conglomerate in Castle Mounain. In this section no important coal beds were seen, and it is resumably above that part of the Chickaloon formation appearing $n$ the section along Chickaloon River. (See pp. 43-46.)

Bection in the Chickaloon formation on the east bank of Kings River at the bend below the

Porphyry sill. coal camp.

Dark shale Ft. in.

Sill of fine-grained basic rock.

Dark shale with ironstone nodules....................... 16

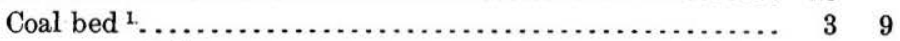

Carbonaceous shale.................................. $1{ }_{2}$

Gray shale with ironstone nodules near base................ $3 \quad 3 \quad 6$

Sandstone and sandy or concretionary shale.................. 34

Gray concretionary shale............................ $4 \quad 4$

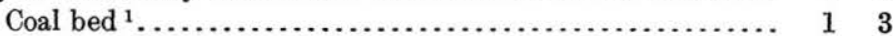

Gray shale with ironstone nodules...................... 15

Gray shale, becoming sandy toward base................. 6

Shale and sandstone.................................. 5

Gray shale with ironstone nodules................... 37

Ironstone........................................... 1

Shale............................................... 38

Sandstone........................................ 13

Shale with ironstone concretions and some sandstone......... 6 6 3

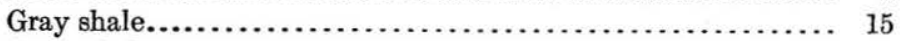

Concealed........................................ 10

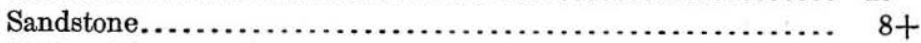

Shale with concretions................................. 45

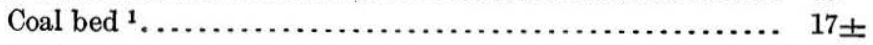

1 For details see coal section 21, p. 81 . 
Section in the Chickaloon formation on Eska Creek 1,100 feet below the forks. ${ }^{1}$

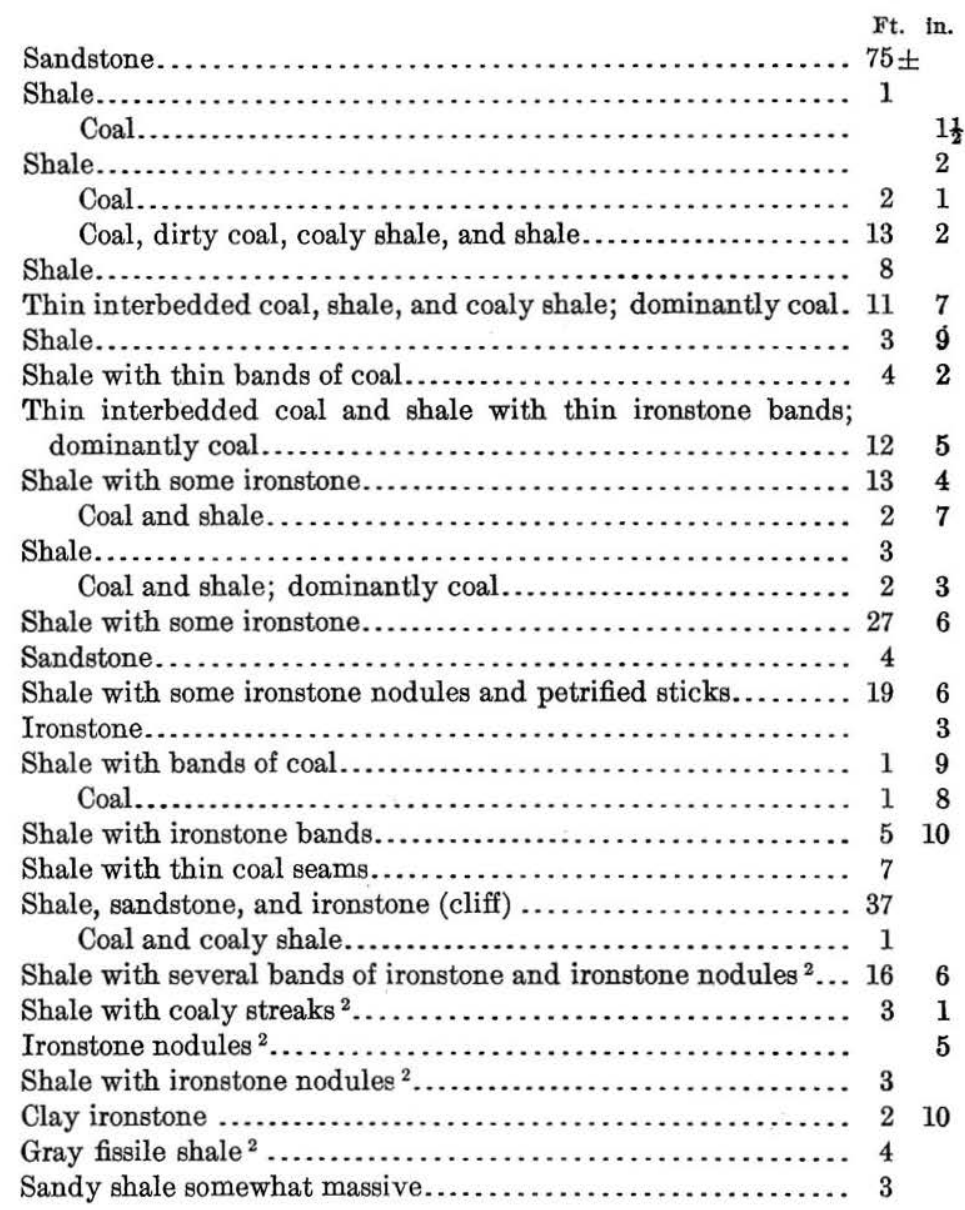

Between the sandstone at the top of the foregoing section and the nearest and lowest outcrop of the Eska conglomerate on Wishbone Hill, about 0.6 mile to the southwest there are no exposures. About $1 \frac{3}{4}$ miles west of this section, on the north slope of Wishbone Hill sandstone, overlying shale and coal, outcrops below the lowest exposure of Eska conglomerate. The concealed stratigraphic interval between them is about 200 feet, and it appears most probable that tha interval between the above section and the conglomerate is at least that much. 
vection in the Chickaloon formation on Matanuska River about one-eighth mile below Moose Creek.

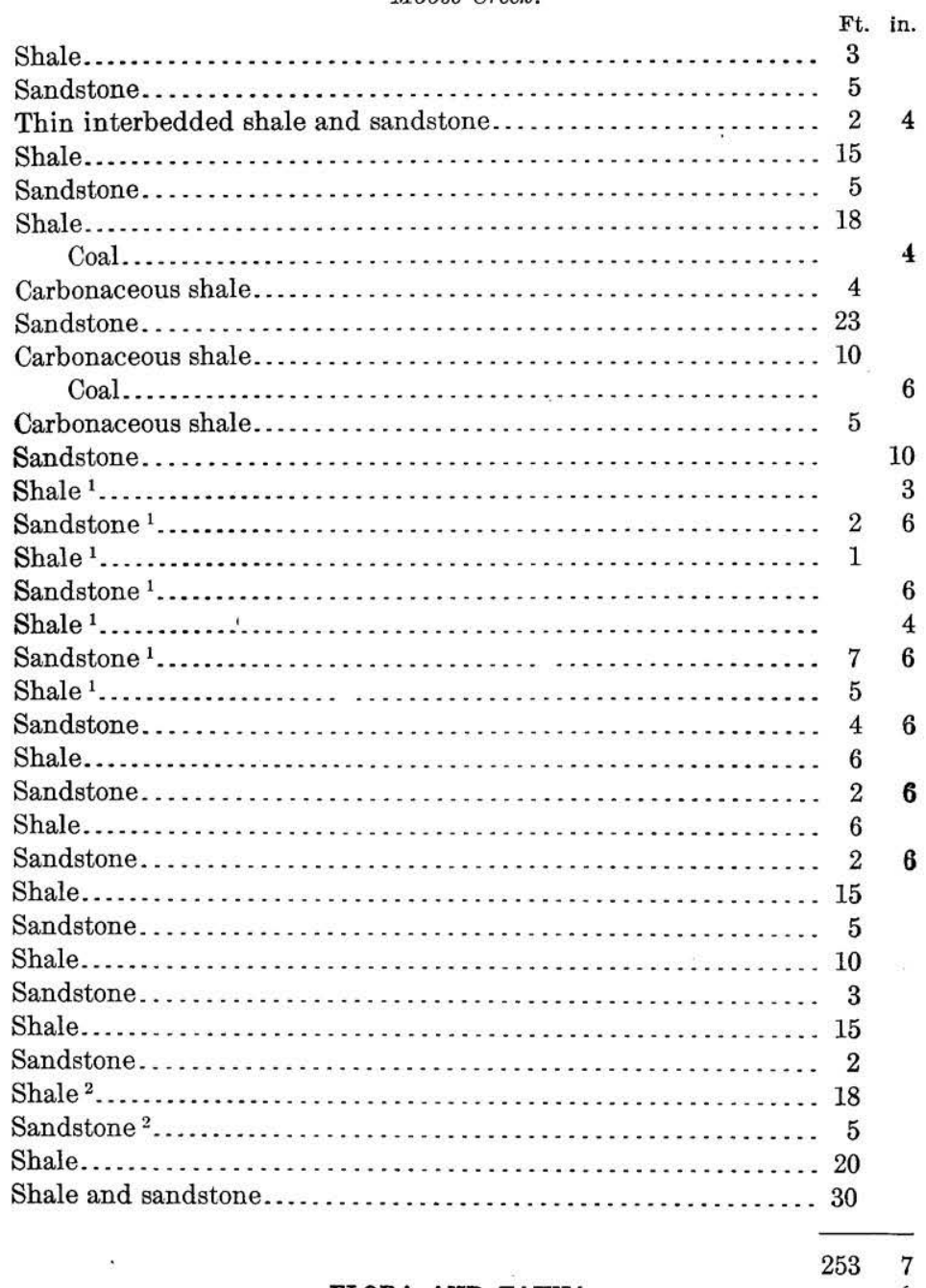

FLORA AND FAUNA.

The fossils observed in these beds consist chiefly of leaves, which are very abundant though in general not well preserved except in the beds of iron carborate. The following species have been identified by Arthur Hollick from material collected by Martin, Katz, and Chapin in 1910.

5892. North bank of Matanuska River, 4,200 feet below Moose Creek:

Onoclea sensibilis arctica Heer $=0$. sensibilis fossilis Newb.

Taxites validus Heer.

\footnotetext{
1 Fossil leaves in lot 5892 collected at this horizon.

${ }^{2}$ Fossil leaves in lot 5901 collected at this horizon. See p. 50.

$9949^{\circ}-$ Bull. $500-12-4$
} 
Sequoia langsdorfii (Brongt.) Heer.

Sequoia nordenskioldii Heer.

Poacites sp.

Quercus chamissoni Heer.

Quercus charpentieri Heer.

Quercus fraxinifolia Lesq.? (fragmentary):

Quercus juglandina Heer.

Quercus laharpi Gaud.

Dryophyllum sp.

Alnus kiefersteinii Heer.

Myrica langeana Heer.

Myrica acuminata Ung.? (fragmentary).

Juglans denticulata Heer.

Juglans heerii Ettingsh.

Ulmus sp.

Laurus primigenia Ung.? (fragmentary).

Cratægus sp.

Prunus serratula Heer.

Sapindus undulatus Heer.

Rhamnus gaudini Heer.

Pterospermites spectabilis Heer? (fragmentary).

Apeibopsis deloesi (Gaud.) Heer=Pterospermum deloesi Gaud.

Brasenia antiqua Newb.? (fragmentary).

Diospyros sp.

Viburnum antiquum (Newb.) Hollick=Tilia antiqua Newb. (Leaves at fruit; fide Ward, L. F., Bull. U. S. Geol. Survey No. 37, 1887, PI. LI, fig 2, 4-8.)

Viburnum asperum Newb.?

Viburnum nordenskioldii Heer.

Age, "Arctic Miocene" (Eocene).

5901. North bank of Matanuska River, 4,800 feet below Moose Creek.

Glyptostrobus ungeri Heer.

Salix reana Heer.

Quercus laharpi Gaud.

Quercus myrtilloides Ung.

Myrica langeana Heer.

Myrica vindobonensis Ettingsh.

Juglans bilinica Ung.

Juglans denticulata Heer.

Rhamnus eridani Ung.

Pterospermites dentatus Heer.

Fraxinus johnstrupi Heer.

Age, "Arctic Miocene" (Eocene).

5897. Eska Creek, west bank, elevation 1,100 feet:

Sequoia langsdorfii (Brongt.) Heer.

Sequoia nordenskioldii Heer.

Taxodium distichum miocenum Heer.

Taxites olrickii Heer.

Phragmites sp.

Poacites sp.

Cyperacites sp. All fragmentary.

Typha sp.

Musophyllum sp.)

Populus acerifolia Newb. 
Populus arctica Heer.

Populus gaudini Fisch.-Oost.

Populus latior $\mathrm{Al}$. Br.

Populus richardsoni Heer.

Salix longa Al. Br.

Corylus insignis Heer.

Alnus kiefersteini Heer?

Juglans acuminata Al. Br.

Juglans nigella Heer.

Ficus grönlandica Heer.

Planera ungeri Ettingsh.

Laurus primigenia Ung.

Cornus macrophylla Heer.

Pterospermites sp. A very large leaf about 2 feet long by $1 \frac{1}{2}$ feet broad.

Viburnum newberryanum Ward.

Viburnum nordenskioldii Heer.

Age, "Arctic Miocene" (Eocene).

6896. Young Creek, 0.6 mile northwest of Kings River:

Flabellaria florissanti Lesq. This lot consists of this one specimen.

Age, Tertiary, presumably Eocene.

902. Shale at diorite contact at big bend of Young Creek, elevation 1,050 feet:

Populus zaddachi Heer? (fragmentary). Two specimens only in this lot. Age, presumably "Arctic Miocene" (Eocene).

1904. Gulch on north side of Red Mountain, 4 miles N. $5^{\circ}$ E. of mouth of Young

Creek, elevation 3,500 feet:

Sequoia langsdorfii (Brongt.) Heer.

Populus gaudini Fisch.-Oost.

Age, presumably "Arctic Miocene" (Eocene).

6908. Young Creek, 0.55 mile north of 2,350-foot forks:

Sequoia langsdorfii (Brongt.) Heer.

Age, presumably "Arctic Miocene" (Eocene).

6899. " $2 \frac{1}{4}$ miles northwest of U. S. L. M. No. 1; elevation 2,750 feet:"

Sequoia langsdorfii (Brongt.) Heer.

Populus arctica Heer.

Quercus olafseni Heer.

Pterospermites alternans Heer.

Age, "Arctic Miocene" (Eocene).

5895. "Talus slope at base of cliff, Kings River, east bank, at Coal Camp, 7 miles above mouth:"

Onoclea sensibilis arctica Heer $=0$. sensibilis fossilis Newb.

Taxodium occidentale Newb.

Populus arctica Heer.

Viburnum sp.

Age, "Arctic Miocene" (Eocene).

The following species have been identified by F. H. Knowlton from material collected by Paige and Knopf in 1906:

Moose Creek, 25 feet above 11-foot coal seam:

Sequoia langsdorfii (Brongt.) Heer.

Ficus? grönlandica? Heer.

Magnolia inglefeldi Heer.

Age, Kenai.

Fragments of other dicotyledons. 
Kings Creek coal:

Ficus? grönlandica Heer.

Populus arctica? Heer.

Rhamnus eridani Heer.

Viburnum sp. cf. nordenskioldii Heer.

Age, apparently Kenai.

Chickaloon coal strata, Watson's camp:

Sequoia langsdorfii (Brongt.) Heer.

Age, probably Kenai.

The species listed below were identified by F. H. Knowlton from material collected by Martin in 1905:

Chickaloon River, roof of coal bed in section 14 on page 80:

Taxodium distichum miocenum (Brongt.) Heer.

Salix varians Heer.

Populus arctica Heer.

Corylus macquarrii (Forbes) Heer.

Juglans nigella Heer.

In addition to the plant remains, shells have been found in the the ironstone (No. 17) in the section on page 44 of this report. Stant says of two collections from this locality:

3316. Bend of Chickaloon River, half a mile above Watson's coal camp: This consists entirely of fresh-water gastropods, of which all but one specimen belong to single species of Viviparus of a type that occurs in both the Upper Cretaceous and th Tertiary. The other specimen is a more slender form, too imperfect for generic detit mination. These fossils are apparently undescribed species -at least they are to Alaska-and they do not fix the horizon more closely than is above indicated.

6698. Bend of Chickaloon River above big coal outcrop.

Viviparus sp.

Probably Eocene.

AGE AND CORRELATION.

The Chickaloon formation is shown by its flora to be certain Tertiary and probably Eocene. It is the local equivalent of at leas part of the Kenai formation of Cook Inlet and is the approximat equivalent of the Tertiary coal-bearing rocks which are present many parts of Alaska.

\section{ESKA CONGLOMERATE.}

AREAL DISTRIBUTION.

The Eska conglomerate occupies two areas. One extends we ward from the valley of Eska Creek, from which the formation named, to Moose Creek, outcropping in beautiful exposures in $\theta$ cliffs of Wishbone Hill. The other is in Castle Mountain, extendi eastward for 4 or 5 miles beyond Chickaloon River. 


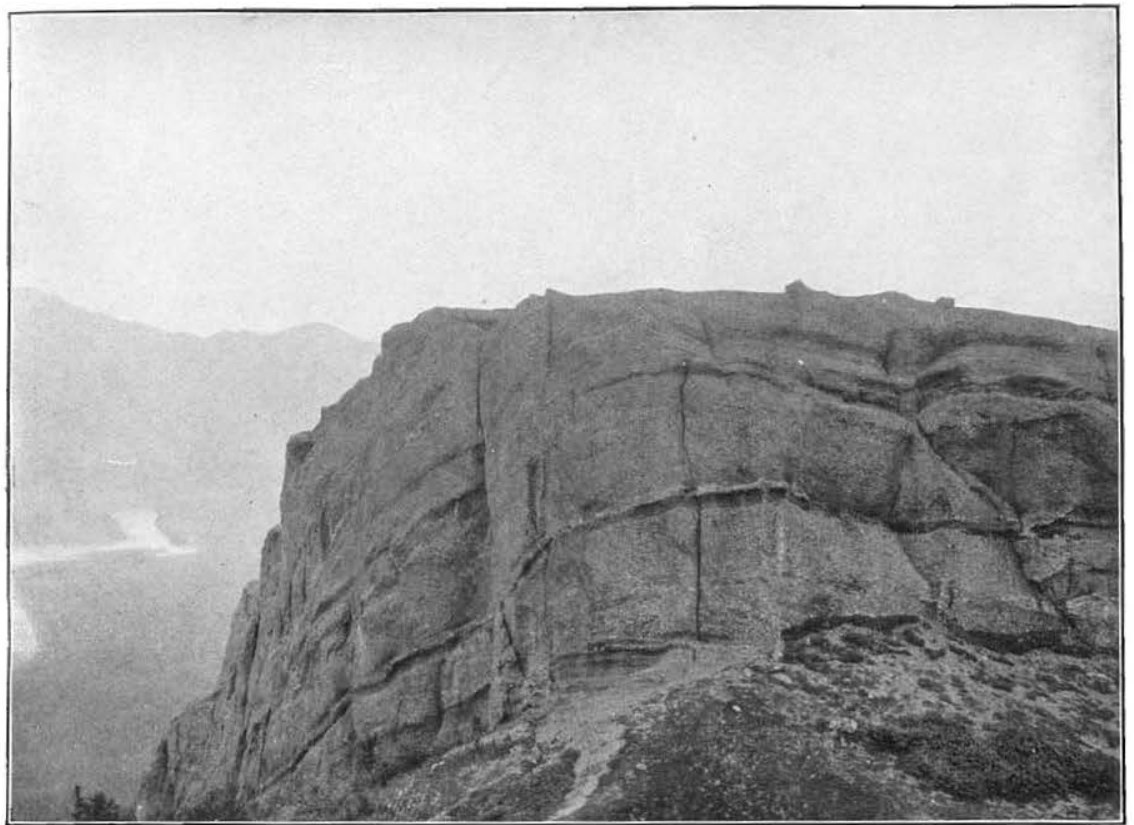

A. ESKA CONGLOMERATE ON WEST WALL OF VALLEY OF ESKA CREEK AT EAST END OF WISHBONE HILL.

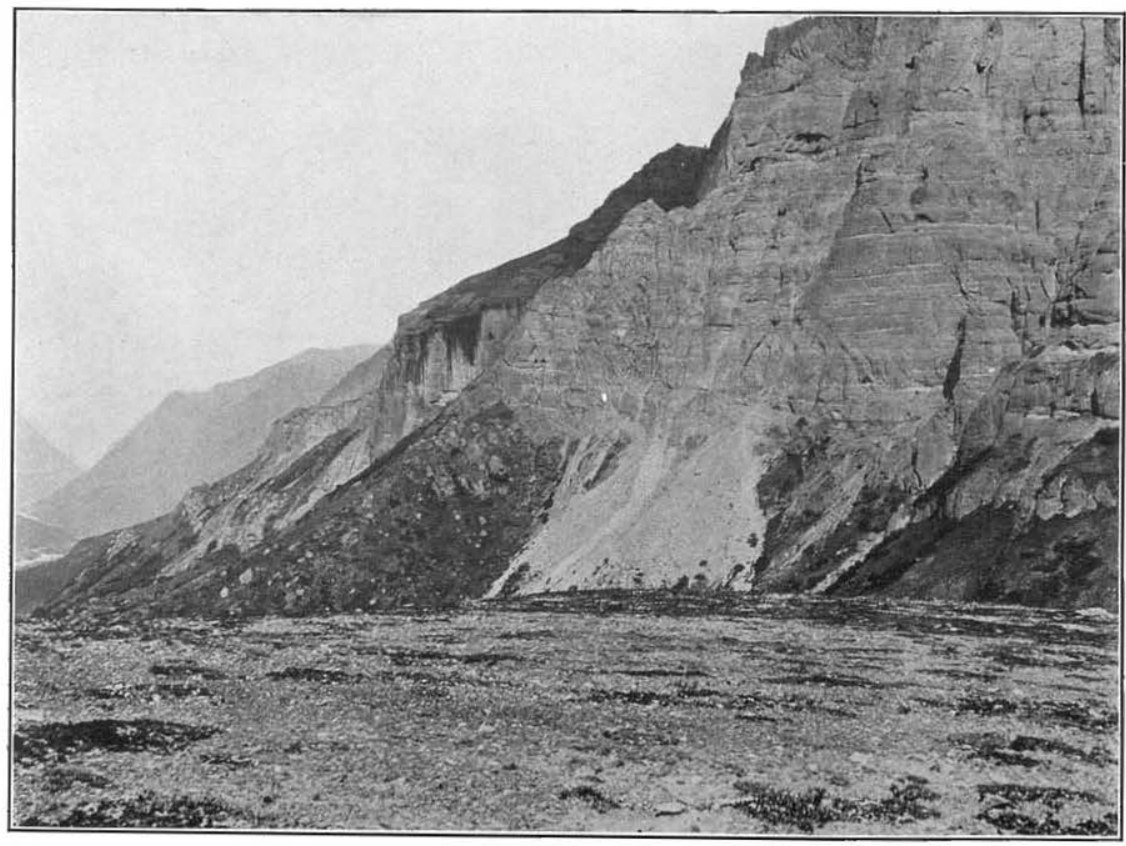

B. ESKA CONGLOMERATE IN WEST END OF CASTLE MOUNTAIN. 



\section{LITHOLOGIC CHARACTER.}

The Eska conglomerate is about 3,000 feet thick and consists of predominantly coarse conglomerate in massive plates interbedded with a very subordinate amount of coarse sandstone.

As exposed in Wishbone Hill the Eska conglomerate (see Pl. IX, A) consists of massive beds of conglomerate in thick plates with some intercalated lenses of coarse sandstones and a small amount of sandy shale. The bedding of the formation is marked only by the intercalated sandstones. The conglomerate is structureless save for a shingling which is only locally distinct. The sandstones are commonly cross-bedded and in some places strongly so. The dominant color of the formation is a light tawny red. Some of the sandstones, however, are whitish or gray. The rocks vary from coarse-grained sandstones or fine conglomerate in which the matrix preponderates to rocks crowded with pebbles up to 6 inches in diameter. Individual beds of conglomerate range in thickness from a few feet up to 75 feet. The sandstone beds are generally thin, although one 25 feet thick was noted. The pebbles range in size up to 8 inches, but most of them are between half an inch and 4 inches. They are well worn into a variety of shapes, of which subround, flattish, and elongate predominate. Some are subangular to shapeless, yet with well-worn corners and edges. The pebbles consist of porphyries of intermediate composition, which are the most abundant, granites, fine-grained igneous rocks, quartzites, and vein quartz. The matrix is sandy or arkosic. The conglomerate is all well indurated, yet it is more resistant where cemented along fractures, so that combs from a few inches to 1 or $1 \frac{1}{2}$ feet high and several inches thick stand up above the general surface.

Some obscure fossil sticks were found in sandstone near the summit of Wishbone Hill.

On Moose Creek about $1 \frac{1}{2}$ miles above the ford on the Chickaloon trail, the conglomerate immediately overlies the Chickaloon formation. It is composed chiefly of granite; the matrix is of granitic débris, and the bowlders are biotite granite and diorite. Among the smaller pebbles are also alaskite, gneiss, graywacke, metamorphic rocks, and quartz. The material is, for the most part, considerably under 1 foot in diameter, but there are a few large bowlders up to 4 feet in length. Lenses of arkosic sandstone occur within the conglomerate. The formation here is less indurated than on Wishbone Hill. The outcrop is crumbly and the bowlders are easily removed with a hammer.

On Castle Mountain the formation consists of conglomerate beds from 6 feet to at least 50 feet in thickness interbedded with strata of arkosic sandstone from 2 inches up to 30 or 40 feet thick. (See Pl. IX, B.) The beds of arkosic sandstone are fairly persistent, but 
some are lenticular. Small beds of finely laminated sandstones were seen. The basal beds of the conglomerate contain pebbles up to nearly 12 inches in diameter. About half of the pebbles are por. phyries, acidic types predominating, and about one-third are black and dark-colored basic aphanitic igneous rock. The remainder are quartz, granite, diorite, other igneous rocks, greenstones, and various metamorphic rocks. The matrix consists of sandy material, with fine particles of igneous rocks, such as porphyries and traps, and dark minerals, such as hornblende and biotite. Locally the beds of sandstone grade into the conglomerate, but as a rule the contacts between them and the conglomerate are fairly definite. The sandstone itself is generally conglomeratic. It is essentially the same as the matrix of the conglomerate. The rocks in Castle Mountain are somewhat lighter colored than those in Wishbone Hill. This is due largely to the greater preponderance of porphyry pebbles which weather readily to a pale-green color.

\section{AGE AND CORRELATION.}

The Eska conglomerate rests upon the Chickaloon formation without observed unconformity. It is overlain unconformably by basaltic lavas and tuffs. No determinable fossils have been found in it, so the only conclusion that can be drawn regarding its age is that it is certainly Tertiary and is possibly the equivalent of the Miocene conglomerates which have been recognized at several points along the Pacific coast of Alaska.

\section{BASALTIC LAVAS AND TUFFS.}

The rocks forming the summit of Castle Mountain are basic volcanic rocks, most of which weather to a conspicuous red color. They comprise dense fine-grained black basalts and gray and reddish-gray amygdaloids and rocks of vesicular flow texture interbedded with tuffs and breccias of like material. There are some shale, sandstone, and conglomerate lenses (?) within the tuff and breccia beds. The lava beds are for the most part dense but in some places have columnar structure in their lower parts and are vesicular in their upper parts, being therefore clearly flows. The denser, more crystalline parts are composed of minute grains of feldspar and augite. The rock is similar to that described by Paige and $\mathrm{Knopf}^{1}$ as an acidic olivinefree basalt composed of doleritic aggregates of labradorite $\left(\mathrm{Ab}_{2} \mathrm{An}_{8}\right)$ and augite, with plagioclase as the dominant constituent. These basalts have very much the same composition as the gabbros and diabases that intrude the coal measures (pp. 63-67).

' Paige, Sidney, and Knopf, Adolph, Geologic reconnaissance in the Matanuska and Talkeetna basins, Alaska: Bull. U.S. Geol. Survey No.327, 1907, p. 30. 
The section in the summit of Castle Mountain (see fig. 1) is as follows:

Section in summit of Castle Mountain.

Feet.

Dense basalt......................................... 130

Tuffs, breccias, and vesicular lavas...................... 170

Dense basalt, in part columnar at the bottom and vesicular at the top. 250

Tuffs, breccias, shale, sandstone, and conglomerate............. 90

Dense and amygdaloidal basalts............................. 210

Unconformity.

Eska conglomerate.

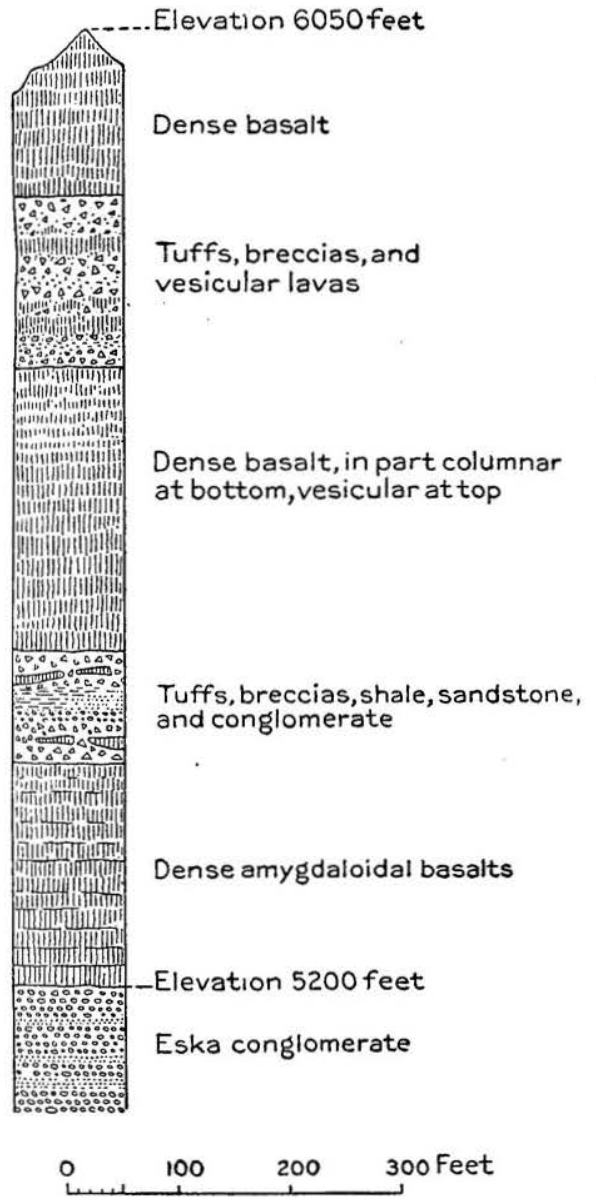

FIgURE 1.-Columnar section in summit of Castle Mountain.

The basalts lie upon an eroded but generally even surface which truncates the Eska conglomerate at a small angle $\left(5^{\circ} \pm\right)$.

The base of the volcanic rocks is a dense, very fine grained basalt which apparently grades upward into a vesicular flow breccia. This is succeeded by beds of basalt, breccias, and tuffs with small amounts of sand and shale, all apparently strictly conformable and (on Castle Mountain at any rate) undeformed. Except the unconsolidated alluvial deposits, these basalts are the youngest rocks in the region. Their equivalence with the gabbros and diabases has been suggested by Paige and Knopf. ${ }^{1}$

TERTIARY INTRUSIVE ROCKS.

The igneous rocks which invade the Tertiary sediments of the region mapped on Plate V (in pocket) fall into three groups which are to some extent but not sharply differentiated by their areal distribution and lithology. The threefold grouping is as follows: (1) Diorite porphyries, including light-colored, usually porphyritic, fine-grained rocks of andesitic, diorite porphyry, and granite por- 
phyry habit, which occur in the south-central portion of the region, especially in a large mass between Young Creek and Kings River, and in many smaller bodies in adjoining areas; (2) trachytic rocks, including greenish and brownish felsitic or porphyritic rocks which occur in two areas near the upper part of Young Creek; (3) diabases and gabbros, including bluish-gray to dark-green and black aphanitic, porphyritic, and coarsely crystalline diabases and gabbros, which are found abundantly east of Kings River but also sparingly throughout the other parts of the region.

\section{DIORITE PORPHYRIES.}

AREAL DISTRIBUTION.

The diorite porphyries are in general restricted to an area extend ing eastward from the lower part of Young Creek to the lower par of Chickaloon River. Within this area they are the more abundan intrusive rocks present. Small masses of rocks of similar petro graphic character were noted along the creeks north of Castle Moun tain and along Carbon Creek, in areas in which the diabases and gabbros are the dominant intrusive rocks.

The larger intrusive masses recognized are situated as follows: In the hill between the lower course of Young Creek and Kings River and north of the lower course of Young Creek is an irregular area 5 miles long and, near its west end, 2 miles wide. Plate XI, $A$, shows the west end of this mass. In the hills west of the lower part of Chickaloon River and north of Matanuska River there are eight or more isolated exposures within an area of 2 or 3 square miles. In the top of the east bank of Kings River is a large sill which should probably be regarded as a prominent apophysis of the mass first noted above, and similarly the large dike and sills (see Pl. XI, B) in the south bank of Matanuska River belong with the second mass noted above.

PETROGRAPHIC CHARACTER.

The rocks described under this heading are all light-colored por phyritic types ranging in composition from granite porphyries through soda syenite porphyries and diorite porphyries to augite andesites The potash feldspar, orthoclase, is not an important constituent of any of these rocks and was not detected in most of them. They arệ? also to some extent characterized by the presence of a colorless orthorhombic pyroxene and by a paucity of mica.

In the northern and western parts of the large mass which lies between Young Creek and Kings River, in the neighborhood of Young Creek (Pl. XI, A), there are light-gray porphyritic rocks in which the groundmass preponderates over the phenocrysts. The phenocrysts are chiefly small white or glassy feldspars; some rocks 


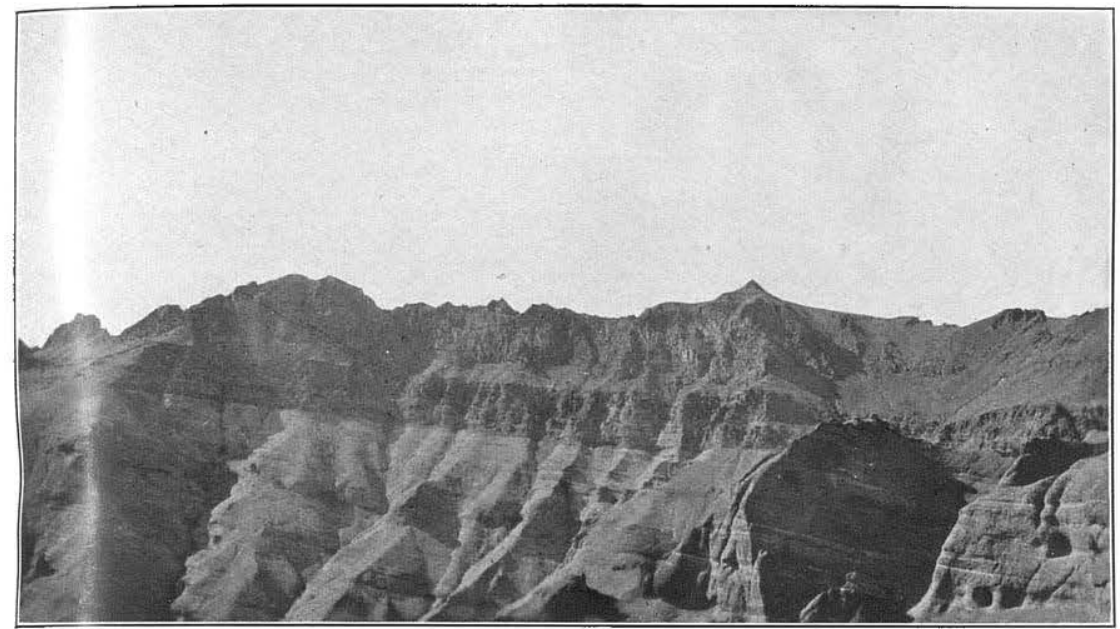

A. TERTIARY LAVAS UNCONFORMABLY OVERLYING ESKA CONGLOMERATE ON CASTLE MOUNTAIN.

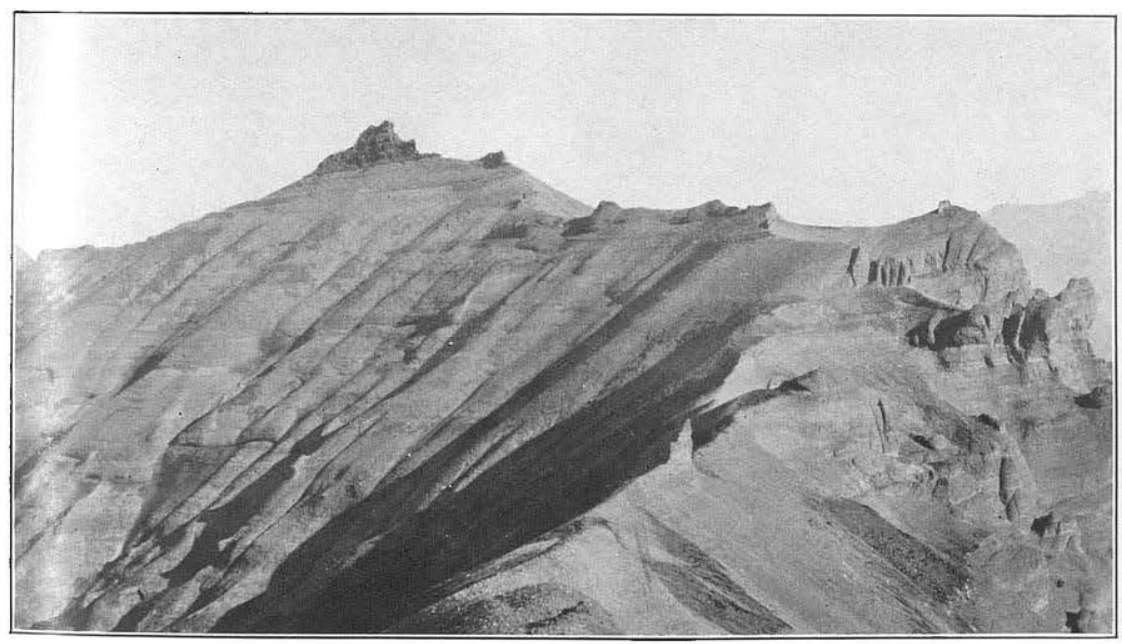

B. ESKA CONGLOMERATE OVERLAIN BY SMALL CAP OF TERTIARY LAVA ON SOUTHEAST SPUR OF CASTLE MOUNTAIN. 



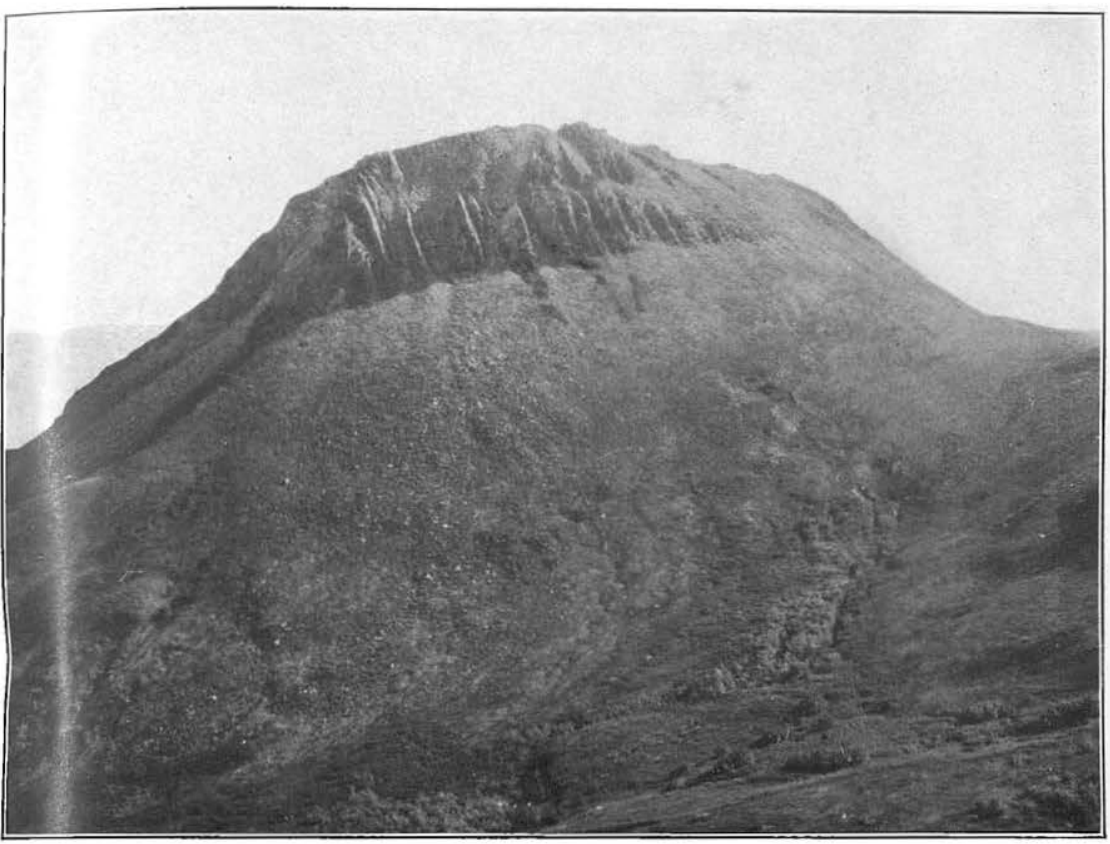

.1. PORPHYRY SILL (?) IN VALLEY OF YOUNG CREEK, OVERLYING CHICKALOON FORMATION.

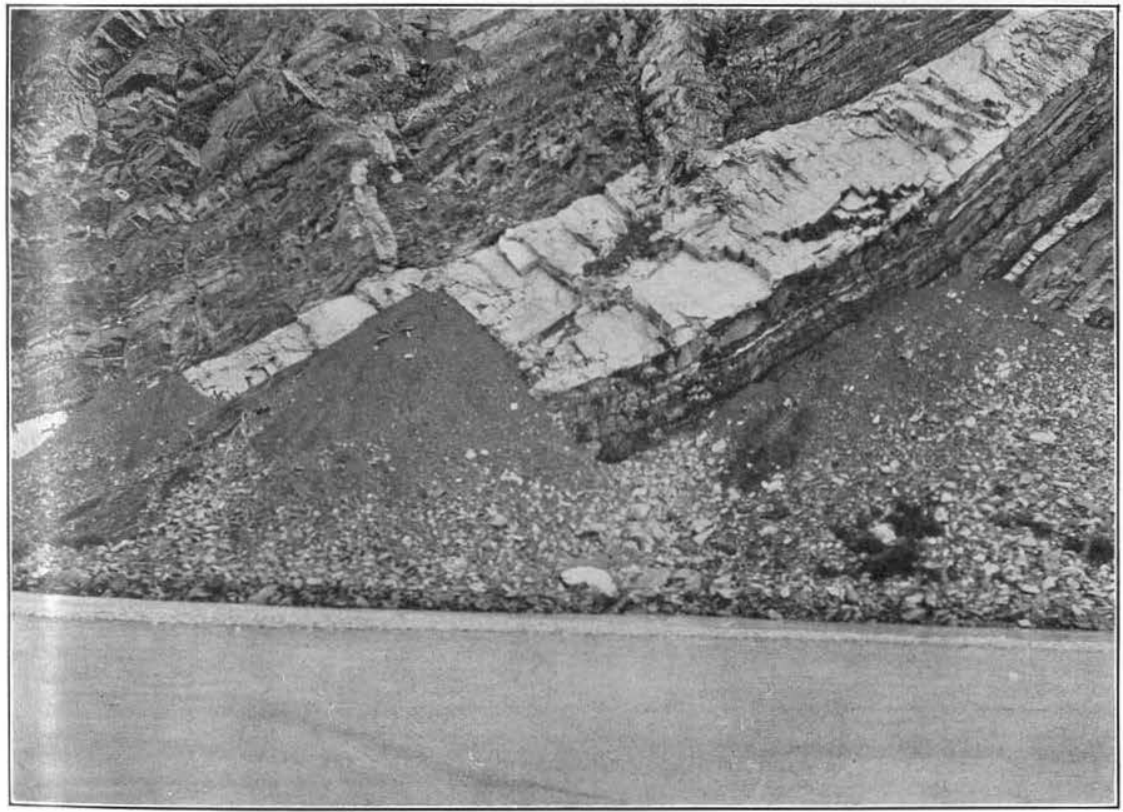

B. PORPHYRY SILLS AND DIKES IN UPPER CRETACEOUS ROCKS ON SOUTH BANK OF MATANUSKA RIVER 2.7 MILES BELOW CHICKALOON RIVER. 

also contain in considerable amount a dark ferromagnesian mineral, which is often found thoroughly weathered and then appears as small black spots. The gray groundmass is either fine grained or very fine grained to aphanitic. In some specimens there are vesicles partly or wholly filled with a pearly, pale leek-green mineral and some calcite. The weathered rocks are commonly yellowish or tawny, and some develop very uneven surfaces. The type specimen, an augite andesite, under the microscope shows feldspar and augite phenocrysts. The feldspar is chiefly labradorite-bytownite and less albite-oligoclase. Zonal growths in which the more acidic feldspars form the outer rims are common. The augite is in almost colorless large subhedral grains. There are also smaller grains of this mineral which approach in size the constituents of the groundmass. The groundmass contains the above-named feldspars and also some orthoclase (?), quartz in considerable amount, and colorless orthorhombic pyroxene in small columnar crystals. Iron oxides and apatite are abundant accessory constituents.

Near the northeastern border of the same intrusive mass are quartz diorite porphyries. These are moderately fine grained porphyritic holocrystalline rocks in which the phenocrysts about equal or preponderate over the groundmass. The phenocrysts, which are closely packed, are principally small rectangular white feldspars, between which are the darker phenocrysts and the minutely granular groundmass. The feldspars are plagioclase, zonally built, and ranging between andesine and labradorite. Other phenocrysts are biotite, colorless augite, and hornblende. The groundmass is quartz and feldspar. The quartz is abundant and partly idiomorphic in a paste of feldspars which, though obscure because fine and weathered, appear to be in part alkalic and in part a lime-soda feldspar. Magnetite and apatite are accessory constituents. Similar rocks in the central and southern parts of the mass have a little more coarsely crystalline groundmass and at several places are slightly different in composition. In one in which the dark phenocrysts are augite and hornblende, the feldspar is in part labradorite and in part alkalic feldspar. In another, whose dark phenocrysts are hornblende and biotite, the feldspar is about andesine in composition.

Some of the sills and dikes which intrude the coal measures and Upper Cretaceous rocks on the east and south of the large intrusive mass discussed above are acidic porphyries. These are in particular the large sill at the Kings River coal camp, the large sill and dikes on Matanuska River below Chickaloon River, and the light-colored intrusive rocks along and west of the lower part of Chickaloon River $(\mathrm{Pl}$. XI, B). They are whitish or light-gray porphyritic rocks. The groundmass, which predominates over the phenocrysts, is either aphanitic or very finely crystalline. The phenocrysts are chiefly 
white or yellowish albite (or albite-oligoclase), idiomorphically developed. There are also biotite phenocrysts and in some specimens a few of quartz. The groundmass is acidic plagioclase and quartz, a small part of the quartz being graphically intergrown with feldspar which may be orthoclase. There is also a small amount of ferromagnesian mineral in the groundmass, but this is weathered beyond recognition in the sections examined. Iron oxide and apatite are accessory constituents. The rock at the Kings River coal camp has erroneously been called a monzonitic porphyry ${ }^{1}$ and might better be given the qualitative name soda syenite porphyry.

A large number of dikes, mostly of small size and very fine texture, in the neighborhood of Kings River and the lower part of Chickaloon River, are probably related to the rocks described above. They are light-colored whitish, gray, or drab felsites or porphyries. A few are amygdular. The rock from one of these dikes, on the creek north of Castle Mountain, in the hand specimen appears to be a uniformly minutely granular and holocrystalline gray rock, but under the microscope it is seen to be porphyritic and possibly in part glassy. There is more of the groundmass than of the phenocrysts, which are only slightly larger than the individual grains of the groundmass. In places in the rock the texture of the groundmass is fluidal (pilotaxitic) by parallelism of the lath-shaped feldspars. The phenocrysts are albite and possibly also quartz. (The quartz noted may be secondary.) The groundmass is composed of intermeshed lath-shaped albite or oligoclase and also anhedral grains of clouded feldspar, quartz interstitial between the feldspars in rather subordinate amount, and abundant small crystals of magnetite and what appears to be chloritic material after ferromagnesian minerals, or may in part be devitrified glass.

A rock intrusive into the Tertiary sediments on Carbon Creek is a light-colored porphyry composed macroscopically of bunches of small white feldspar phenocrysts in a gray aphanitic groundmass. The groundmass is dominant over the phenocrysts. The feldspar phenocrysts are albite. The groundmass is composed of small intermeshed lath-shaped feldspars, probably acidic plagioclase, with very little quartz. There is also in the groundmass magnetite and considerable but obscure weathered ferromagnesian mineral or glass. Calcite and chlorite are abundant secondary minerals.

LOCAL RELATIONS.

The diorite porphyries and allied rocks are distributed through the region between Young Creek and Chickaloon River. They are in contact with Upper Cretaceous rocks and Tertiary coal measures.

1 Martin, G.C., A reconnaissance of the Matanuska coal field, Alaska, in 1905: Bull. U. S. Geol. Survey No. 289,1906 , p. 16. 
The andesite and diorite porphyry mass between Young Creek and Kings River is in its central portion a moderately coarse grained rock, peripherally a fine-grained holocrystalline porphyry which is in places miarolitic, and at the extreme margin in local narrow bands a porphyry with aphanitic groundmass. The intrusive relations of this rock are clearly shown at several points near its border.

On the west bank of Young Creek, about 1 mile above Kings River, Tertiary sediments directly overlie the igneous rock, which is here a felsite porphyry. The shales and sandstones are indurated by contact metamorphism (baked) to hard dense fine-grained rocks, and the intrusive is also dense and fine grained, so that the exact contact is not easily detected. A short distance down the creek from this locality about 30 feet of shale overlies the igneous rock, the surface of which is about parallel to the bedding of the shales. (See fig. 2.) Near the contact the igneous rock is dense and aphanitic, but at a little distance it becomes porphyritic. In the lower foot the shale is very completely indurated and in the succeeding 3 feet is

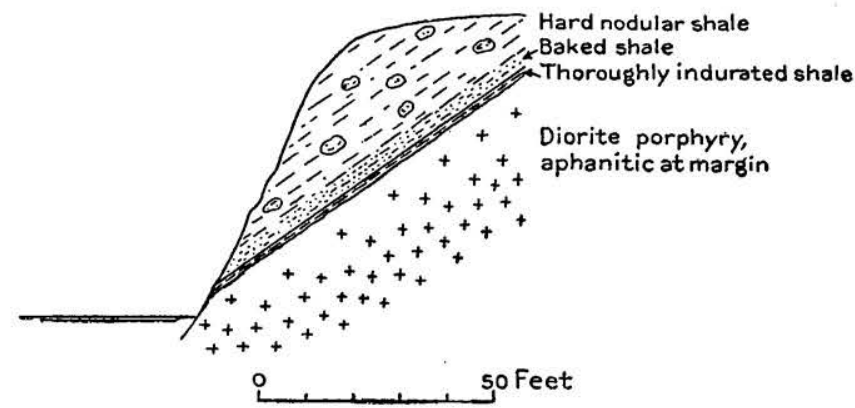

FIGURE 2.-Section in cliff on Young Creek, showing relation of diorite porphyry to Tertiary sediments.

baked to a hard dense rock. About 2 miles above the mouth of Young Creek, entirely within the intrusive mass, there is a small area of Tertiary shales and sandstones. Through a distance of 400 feet along the creek these rocks lie above the intrusive, which is very fine grained, porphyritic, and slightly vesicular at the contact. There are some 30 feet of shales and sandy shale which are nearly horizontal. They are baked through a thickness of at least 25 feet and have been changed from soft shales to very firm and hard lighter-colored rocks.

Tertiary shales of the Chickaloon formation are in contact with the diorite porphyry about three-fourths of a mile up the first northerly tributary of Young Creek (Pl. XI, $A$ ). These shales are indurated. They lie along the creek topographically below the diorite porphyry in the ridges, so that the diorite appears to overlie the shales. This, furthermore, appears to be the general relation of the Upper Cretaceous as well as the Tertiary sediments which are exposed on the north side of the diorite porphyry north of Young Creek. 
Along the fourth mile of Young Creek above the mouth the contact of the diorite porphyry with the Tertiary sediments is in the south bank. Here the igneous and sedimentary rocks are faulted against each other. There is at some places a fault breccia zone, 100 feet or more wide, affecting both rocks. The intrusive porphyry is much saussuritized, shattered, and veined with calcite. The masses of shale and other sediments included in the brecciated zone are also shattered and veined, but not so extensively as the diorite porphyry. (See fig. 3.) At several places on this part of the creek, along the general position of the contact, outcrops of both igneous and sedimentary rock, slickensided or shattered, indicate movements which must have been subsequent to the intrusion, for the evidence elsewhere is conclusive that the diorite porphyry is intrusive into the Tertiary sediments. There may be faults of considerable magnitude that essentially determine the present surface outline of the rock

N.

s.

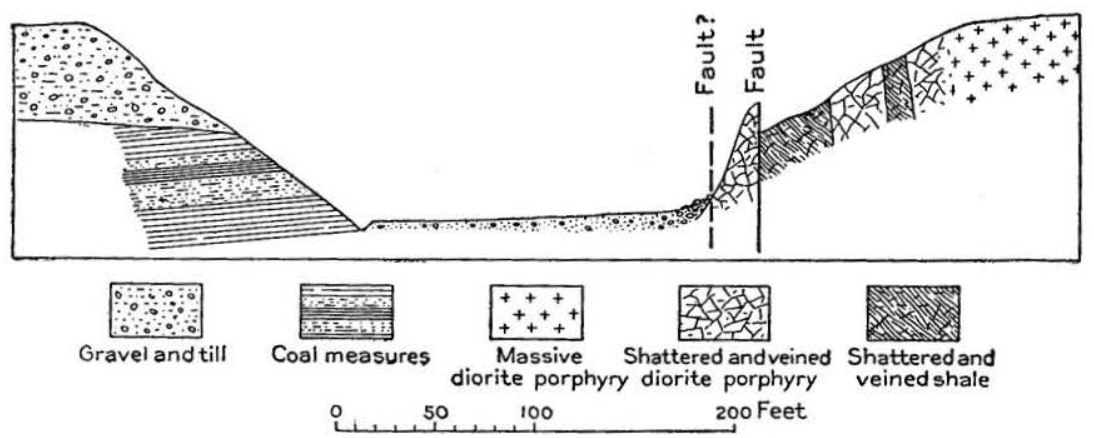

FIGURE 3.-Section on Young Creek showing relation of diorite porphyry to Tertiary sediments.

masses, or the faults may merely represent slight compensatory movements during the cooling of the intrusive mass.

About a mile north-northwest of Kings River Bridge the same diorite porphyry mass whose relations to the Tertiary sediments are discussed above is in contact with Upper Cretaceous sandstones and shales. The contact appears to be intrusive because of the markedly ${ }^{\circ}$ porphyritic border phase of the igneous rock and because the sandstones nearest the porphyry are indurated and altered. The sandstones and shales outcrop below and dip toward cliffs of diorite porphyry. The conditions thus suggest that the igneous rock overlies the sediments and that it is here the edge of a sill-like or laccolithic mass.

The above-described contact relations of the diorite porphyry mass are along its western and northern borders. The rock extends southeastward to the flats of Kings River, where its limits are obscured by the alluvial deposits of that stream. 
The many small masses of porphyries petrographically allied to the diorite porphyries are clearly intrusive into Upper Cretaceous rocks and Tertiary coal measures (Chickaloon formation). Structurally they are sills and dikes which are for the most part of regular outline. Except the very large sills, they have little or no metamorphic effect on the rocks they invade. At Kings River coal camp one sill which is 60 feet thick has visibly indurated the shales beneath it through a distance of less than a foot.

On Chickaloon River at several localities the light-colored porphyry sills parallel the folded beds of the Chickaloon formation, as indicated in figure 4 . The beds seem to be too sharply and complexly deformed to permit an invading magma to follow the folds. It is more probable that, had the intrusion been subsequent to the folding, the intrusive, rather than insinuating itself for considerable distances along single much-distorted bedding planes, would have cut across beds along joints and minor faults, which are numerous. It would appear, therefore, that the intrusion of the diorite porphyry and allied rocks preceded at least a considerable part of the deformation of the Tertiary coal measures (Chickaloon formation). This is further

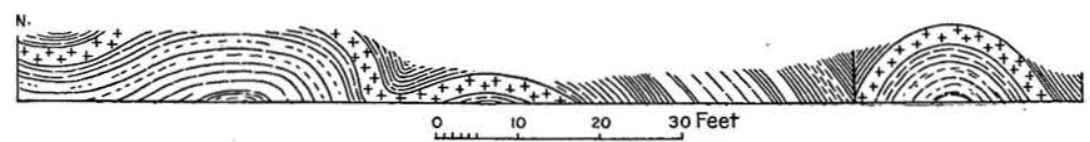

FrgurE 4.-Folded beds of the Chickaloon formation and sill.

suggested by the above-discussed fault, which marks part of the north boundary of the large diorite porphyry mass and which may be of considerable magnitude.

TRACHYTIC ROCKS.

AREAL DISTRIBUTION.

The trachytic rocks were seen only in the upper part of the valley of Young Creek, where they occur in two large masses. One of these occupies what is called Red Mountain and the other is about a mile northeast of it.

PETROGRAPHIC CHARACTER.

The type rocks from Red Mountain are either greenish-gray or brown porphyries in which feldspar and mica phenocrysts only are visible in a felsitic base. The feldspar phenocrysts are long and slender. Under the microscope the several specimens look very much alike. They are trachytic (fluidal-textured) porphyries, the groundmass strongly predominating over the phenocrysts. The phenocrysts are plagioclase and biotite. The former ranges from albite to oligoclase, and some pieces have inclusions of quartz and 
glass. Most of those examined under the microscope are very long, slender laths and appear to have been broken and in part replaced by quartz and to have undergone other alteration. Other more compactly shaped feldspar phenocrysts also showed slight crushing effects. The groundmass is composed of lath-shaped feldspars (acidic plagioclase and possibly also orthoclase), biotite in subhedral grains, abundant small idiomorphic crystals of magnetite, and a little glass. Interstitial primary quartz is present in accessory amounts only. On the east of Young Creek, opposite Red Mountain, the rocks of this group are greenish-gray felsites with a few sparse phenocrysts of feldspar. They are fine-grained and locally slightly trachytic rocks which consist of acidic plagioclase (and orthoclase?) phenocrysts and also considerably altered ferromagnesian phenocrysts in a groundmass made up chiefly of acidic plagioclase and quartz. The plagioclase of the groundmass is lath shaped, for the most part irregularly intermeshed but locally in rudely parallel arrangement. The groundmass contains also some biotite or pyroxene, very much decomposed, and a little devitrified glass. Minute crystals of magnetite are abundant, and apatite is a fairly constant accessory. One of these rocks is a yellowish-green (weathered) porphyritic felsite which contains minute microscopic red garnets. These are about the only phenocrysts visible without the microscope. This rock contains considerable quartz in the groundmass, but, save for this and the garnets, is very like the rock just described. Some of the garnets have macroscopically sharp crystal outlines, but those seen in thin section are irregularly bounded. They contain numerous inclusions of quartz and other minerals, and are surrounded by calcite of secondary origin. There is considerable calcite and other secondary material throughout the rock.

The felsitic and porphyritic rocks of this group, taken as a whole, are more weathered than the dioritic rocks of the first group. One of the trachytic rocks, furthermore, shows slight effects of crushing, a phenomenon not developed in the dioritic rocks.

LOCAL RELATIONS.

The trachytic rocks were found in Red Mountain and the hills northeast of it on the opposite side of Young Creek. Their main masses have no visible contacts with other rocks except that some dikes of similar character cut the surrounding Upper Cretaceous beds and Tertiary coal measures. In Red Mountain the igneous rocks of this group occupy the summit and lie at greater elevation than the neighboring rocks. Coal within less than 50 feet is not visibly different from coal exposed at long distances from the trachytic rocks. There is here a suggestion that the igneous rocks overlie the sediments. A dike of small size similar in character to the Red 
Mountain rock cuts folded Tertiary sediments in the saddle west of Red Mountain and with them is faulted (?) against Upper Cretaceous shales and sandstones.

Rocks similar to those of Red Mountain occurring east of Young Creek are surrounded partly by Tertiary and partly by Upper Cretaceous sediments, but the relations are obscure except where a large dike cuts the Upper Cretaceous beds.

DIABASE AND GABBRO.

AREAL DISTRIBUTION.

The more basic igneous masses occur chiefly within an area beginning at the knoll east of Kings River and at the southwestern base of Castle Mountain and extending eastward beyond the region covered by the detailed map ( $\mathrm{Pl}$. V, in pocket). The northern boundary of this area is along the south base of Castle Mountain, and the area is defined on the southwest by a line from the knoll east of Kings River southeast across Matanuska River. No intrusives other than those discussed under this heading were noted within this area. Twenty masses were mapped within the area described above, and there are a great many smaller ones. The larger masses are those which outcrop in the knolls north and northwest of Chickaloon, along Chickaloon River, and in the hills east of Chickaloon between Boulder Creek and Matanuska River. Eight of these have a surficial extent of one-fourth to one square mile or more. Smaller dikes and sills of diabase were seen outside of the general area described above, along the gorge of Kings River, on the creek tributary to Kings River north of Castle Mountain, in the basin of Young Creek, on Wishbone Hill, and on Arkose Ridge.

PETROGRAPHIC CHARACTER.

All the rocks are very similar in constitution, although they present considerable differences in appearance. There were seen in the region a few small dikes of amygdular basaltic rock of dark color in which, under the microscope, only labradorite is determinable in a microgranular, much weathered groundmass. Blue-gray or greenishgray fine-grained sills are very numerous. These are usually ophitic in texture and composed of labradorite, augite, and iron oxide. They are as a rule considerably weathered, calcite, chlorite, and limonite, being developed from the pyroxene. The gabbroic rocks are for the most part coarse dark-green to black rocks composed of labradorite, common augite, magnetite, and ilmenite. They are slightly ophitic in texture, particularly in the finer-grained varieties which form the borders of large masses or make up the whole of narrower dikes and sills. A number of these are quartz diabases having a notable amount 
of quartz interstitial between the feldspars. In other respects these quartz diabases are not different from the normal diabases of the region. In some places lighter-colored bands or dikelike masses. usually of small size, traverse the coarse gabbros, from which they differ slightly in texture and composition. One fine-grained variet contains, besides the usual constituents, zonally developed plagid clases which vary from bytownite to albite, the interior zones bein the more calcic. This rock contains also primary quartz. Other varieties are coarse grained, composed chiefly of plagioclase and augite, the former being dominant. Bands of this rock a few inches thick traverse normal gabbros. Under the microscope there seem to be no difference between them other than in size of grain, which changes abruptly. Olivine gabbros with but little olivine, and other respects like the usual rocks of the region, were noted at tw localities.

LOCAL RELATIONS.

The rocks of this group are developed chiefly in the eastern pan of the region considered, but are also found sparingly in the westerm part. With only one or possibly two exceptions, so far as known they are all intrusive into the Tertiary arkoses and coal measures (Chickaloon formation). The exceptions are a small gabbro dike which cuts Upper Cretaceous shales in a gulch about $3 \frac{1}{4}$ miles north of the mouth of Young Creek and a gabbroic rock on the south side of Matanuska River $2 \frac{3}{4}$ miles below Carbon Creek, which is near but not in visible contact with Upper Cretaceous beds. In the latter occurrence both the petrographic character and the structural relations of the rock are uncertain.

Small basaltic and amygdular dikes and sills occur in Tertiary, beds exposed in Arkose Ridge. About $5 \frac{1}{2}$ miles N. $10^{\circ} \mathrm{W}$. of the mouth of Moose Creek an amygdaloidal basalt, intruded approximately parallel to the bedding of the arkose above it, is cut off by a fault. Two miles west of this are some very small basaltic dikes and sills in shaly members of the same series.

On the north side of Wishbone Hill, in the sandstone below the conglomerate, there is a small intrusive gabbro mass.

In the Young Creek region two diabase dikes were seen on Division Creek. One 2 miles N. $75^{\circ} \mathrm{W}$. of the mouth of Young Creek is 25 feet thick. It cuts coal-measure beds about parallel to their strike but with opposite dip.

Gabbro cuts the coal measures on Young Creek about 3 miles up from the mouth. The coal at the contact is coked, and the other sediments are indurated. The gabbro is exposed for 150 feet. It is very fine grained and bluish at the intrusive margin and fine grained but distinctly gabbroid elsewhere. Except at the intrusive contact 


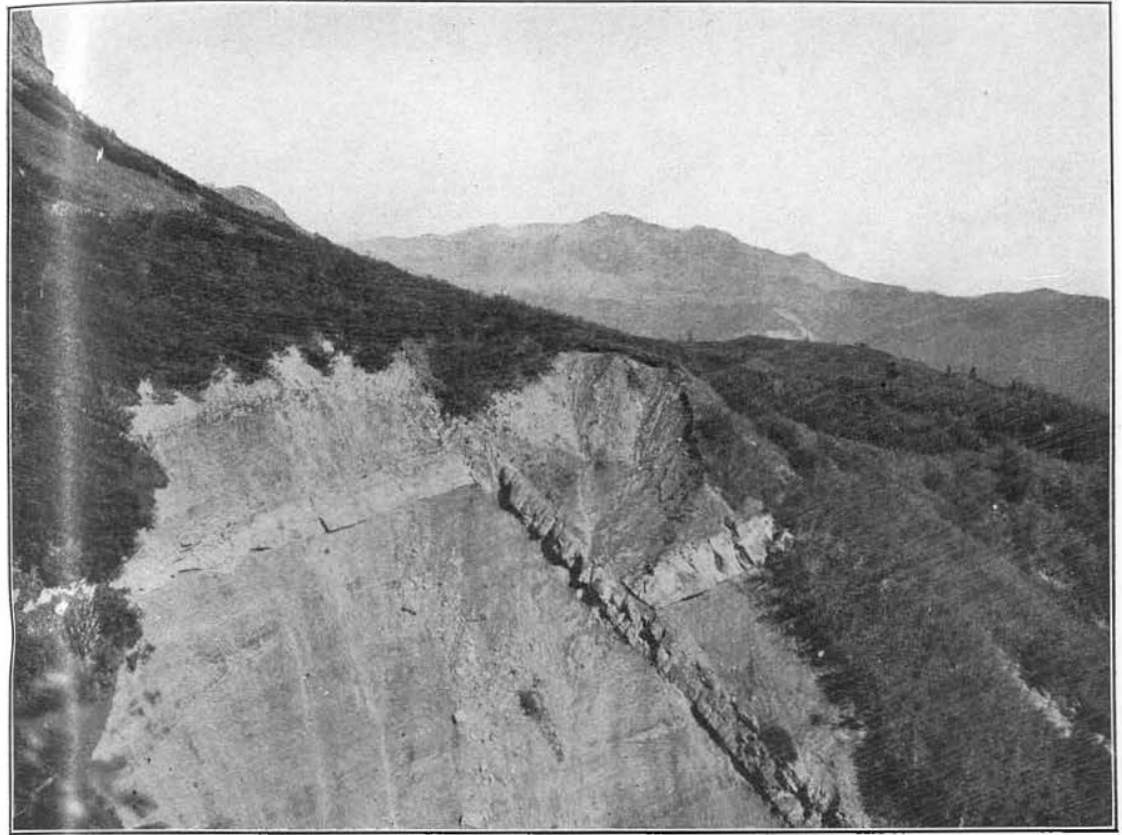

A. DIABASE DIKE ON FAULT IN CHICKALOON FORMATION AT BASE OF CASTLE MOUNTAIN.

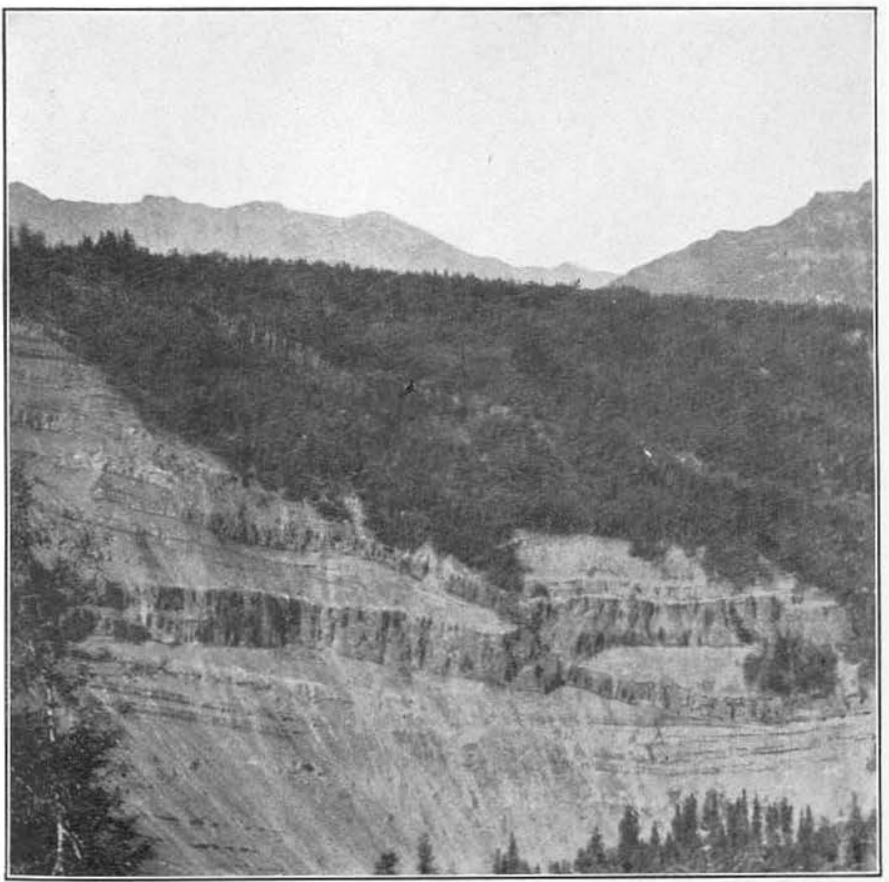

B. DIABASE DIKES AND SILLS IN CHICKALOON FORMATION ON NORTH BANK OF BOULDER CREEK. 

noted its relations are obscured by several displacements. The locality is along the faulted contact of coal measures and diorite porphyry, and it seems probable, though not at all certain, that at one point where gabbro and diorite porphyry appear to be contiguous the former intrudes the latter. The faults which cut the gabbro appear to be of minor importance and are about normal to the main coal measures and diorite porphyry fault contact.

There are a number of diabase intrusions in the Chickaloon formation along Kings River. These are in masses from 1 or 2 feet up to 12 feet thick and of considerable extent which are parallel to or very closely follow bedding planes. They have no noticeable metamorphic effect on any beds except where they come into contact with coal. A large sill at the Kings River coal camp has coked the lower half of a 16-foot coal bed immediately above it.

East of Kings River the gabbros and diabases are abundantly developed in the Tertiary coal measures. The very numerous smaller bodies, which are fine grained and ophitic, are usually sills-

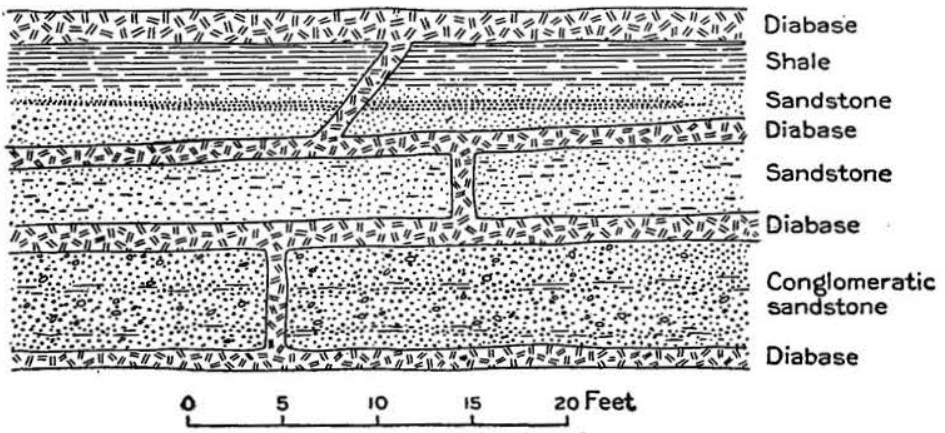

FiguRE 5.-Diabase sills and dikes in the Chickaloon formation near Chickaloon.

that is, they are concordant, or approximately so, with the beds in which they are seen. A few dikes were noted. Four or five small dikes on Matanuska River about a mile below Chickaloon River are anastomosing dikes roughly parallel to the dip of the shales which they intrude. At a locality near Chickaloon small dikes have broken through thin beds of sediments between a number of closely spaced sills. (See fig. 5.) A diabase dike 6 to 10 feet thick is intruded on a fault near the south base of Castle Mountain. (See Pl. XII, A.)

A number of diabase intrusions on Boulder Creek cut the Tertiary beds at a very low angle and in part are parallel to the bedding. A large mass, 20 feet or more thick, through most of its length parallels closely the bedding but at one point is offset as if following a slight displacement of the inclosing beds. At that point there are two branch dikes, one on either side, which appear to fol- 
low the joint or fault that has caused the offset in the large dike. (See Pl. XII, B.) In the vicinity of this complex dike are several

s.

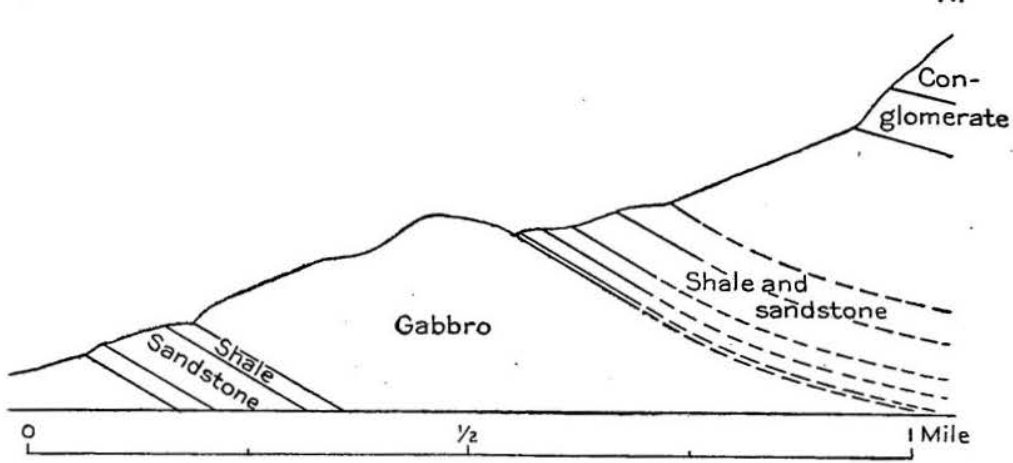

FIGURE 6.-Section at south base of Castle Mountain, showing relation of gabbro to Tertiary sediments.

others of apparently less extent and very nearly parallel to the bedding.

N.

S.

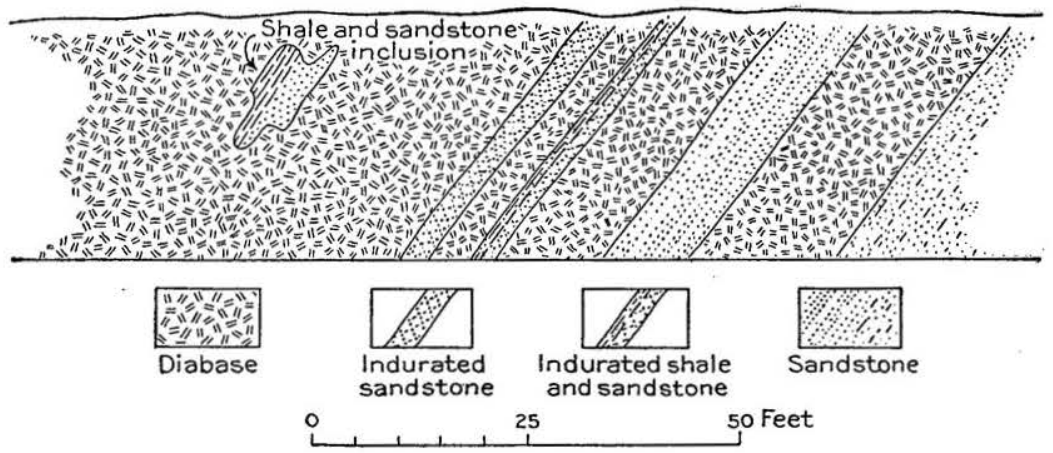

FIGURE 7.-Section along cliff on west bank of Chlckaloon River, showing relation of diabase sills to Chickar loon formation.

The larger masses of basic intrusive rock, the coarse crystalline gabbro, are to a considerable extent also injected along bedding

N.

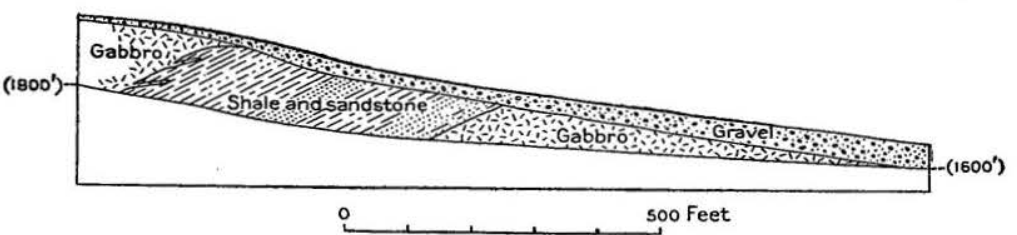

FIGURE 8.-Section in bank of creek $1 \frac{3}{4}$ miles northwest of Chickaloon, showing relation of gabbro to Chick 2 Ioon formation.

planes. They are for the most part either thick sill-like bodies or flat laccolithic bodies like those shown in figures 6,7 , and 8. Such 
are most of the gabbros south of Castle Mountain and along Chickaloon River. Some, however, break across bedding as is indicated in figure 9.

The gabbro masses east of Chickaloon River and between Boulder Creek and Matanuska River are distributed in an arc about a central mass of gabbro. This arc parallels the outline of the central mass. Sandstone was observed at one locality outcropping at the outer base of the gabbro cliffs and apparently underlying them. At

N.

s.

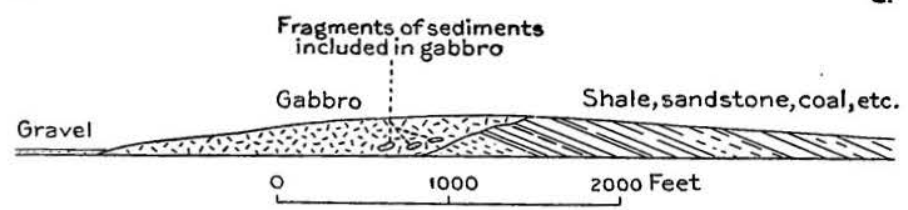

FGGURE 9.-Section in cliff on east bank of Chickaloon River, showing relation of gabbro to Chickaloon formation.

another locality what is probably the same gabbro injects overlying shales. (See fig. 10.) The central mass of gabbro which makes the hill 2 miles east of Chickaloon is sheeted by a platy parting, and along planes parallel to the parting are narrow bands of coarser light-colored gabbro. These partings are very probably cooling joints developed parallel to the surface of the igneous mass. By their attitude they support the suggestion gained from the distribution

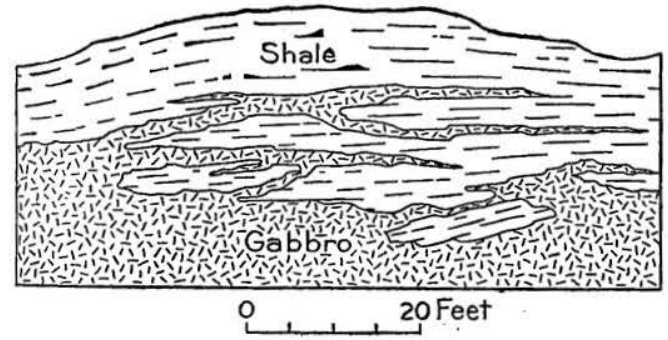

FIGURE 10.-Gabbro injected into shale, south of Boulder Creek. of the gabbro that there areheretwoheavygabbro sheets which are slightly dished and pitch southwest.

The gabbros and diabases were nowhere seen to be folded like the coalmeasure beds they invade and they are faulted only locally and to an unimportant extent. They are probably younger than the principal and important deformation which affected the coal measures and therefore are younger than the diorite porphyries and allied rocks.

\section{QUATERNARY DEPOSITS.}

The unconsolidated Quaternary deposits of the Matanuska Valley include morainic deposits, terrace gravels, and the alluvium on the flood plains of the existing streams. These deposits cover the greater part of the surface, except on the cliffs and steep mountain 
slopes and the higher mountain summits. They are represented on the geologic map only in their better development-that is, where they constitute the most characteristic feature of the areal geology.

\section{MORAINIC DEPOSITS.}

Glacial moraine material is present in at least a thin film over nearly the entire area here described. It is better developed toward the west end of the Matanuska Valley than at corresponding altitudes farther east. The gentler slopes of the valley below elevations which rise from about 2,000 feet in the valley of Moose Creek to about 3,000 feet in the valley of the Chickaloon River are practically all covered with moraines except where recent stream erosion has removed these deposits or where the slopes are too steep to retain unconsolidated material. The glacial deposits are much thicker west of Young Creek than east of it, the reason for this difference lying in the facts that the deposits were formed by a large glacier which formerly occupied the entire length of the valley and that the region below Young Creek was one in which the glacier received only smaller tributary ice streams and consequently deployed over the lowlands, being therefore less actively erosive than above. The abundance of glacial débris in this western part of the region indicates that for a long time the advance of the ice was so balanced by melting that the foot of the glacier was held in this neighborhood, hence the large accumulations. This former Matanuska Glacier probably filled the entire valley from side to side, its margins coinciding approximately with the present positions of the linear mountain fronts which border the valley. It probably extended westward beyond the present limit of the valley and very likely joined other large glaciers of similar character to form a greater ice mass which occupied at least a part of what is now Cook Inlet. Gravel ridges which were regarded as bits of lateral moraine and which probably mark a resting stage of the glacier, if not the extreme lateral position, were seen at the base of Arkose Ridge, north of Moose Creek, at an elevation of about 2,200 feet. These ridges are considered as marking the position of the edge of the ice during its largest extension of any considerable duration. The distribution of the morainic material and the evidence of glacial erosion indicate that at this stage the margin of the ice rose steeply eastward, being at an elevation of about 3,200 feet between Eska and Granite creeks, and at least 3,500 feet in the vicinity of Castle Mountain. East of Kings River evidence concerning the precise position of the edge of the Matanuska Glacier is not at hand, the problem being complicated by the fact that it is impossible to differentiate between material left and erosion forms caused by the glacier occupying the main valley and by the small local glaciers which occupied tributary valleys and which may or may not have been confluent with the main ice 
mass. It is certain that many smaller glaciers existed and probably . every small valley in the high mountains was occupied by one.

The mountain masses adjacent to the Matanuska Valley were probably during the period of maximum glaciation a nest of multitudes of glaciers among and between which peaks and ridges and possibly broader areas of bare rock protruded. There is, however, no evidence that the whole region was swept over by glaciers of anything like the continental type.

Glacial deposits are beautifully developed in the low hills along the lower courses of Moose and Eska creeks and in the area under 800 feet in elevation which lies between them. Exposures are few except where the larger streams are at present vigorously cutting, but the character of the topography is that of typical glacial deposits formed at a period of partial stagnation of the ice. These deposits are somewhat obscured along the present drainage lines by terraces and terrace gravels which have been cut into and built over them. Back from the present drainage lines they exist in essentially unmodified form. East of Granite Creek deposits of this type are less well developed, the glacial deposits being thinner. They are, however, to be seen at the lower elevations in the region between Kings and Chickaloon rivers.

There is abundant physiographic evidence of intense glacial erosion in the valleys of Kings and Chickaloon rivers and farther east. The porphyry hills on Young Creek show clearly the effect of glacial scour. The morainic mantle is here thin; the hilltops and in many places the lower slopes of the hills are swept bare, having only a few glacial pebbles and bowlders scattered over them. The rock surfaces show typical glacial rounding and gouging and many of the rougher slopes and cliffs were produced by plucking, a mode of erosion facilitated by the parallel jointing of the diorite.

\section{TERRACE GRAVELS.}

The terrace gravels are of two kinds. The most broadly developed occur at low altitudes, not having been seen above about 1,100 feet. These are found on well-developed cut and built gravel benches which rise in a series of steps along the river. In the valley of Moose Creek they were noted at elevations of about 400 to 1,000 feet, the bestdeveloped benches being at approximately 400, 450, 500, 670, 825, and 1,000 feet. On Eska Creek there are well-developed benches at about 940 and 1,000 feet. Between Eska and Granite creeks benches were noted at elevations of $660,680,720,740,850,950$, and 1,150 feet. In the valley of Kings River there are many well-developed terraces of which the highest is at about 1,200 feet. On Chickaloon River the best-developed terraces are at about 1,000 feet. The position of some of the terraces observed in the different parts of the area is 
indicated on the geologic map (Pl. V, in pocket) and profiles of the. terraced banks of Moose Creek and of Kings River are given in figure 11. The character of the material in which these terraces are developed is shown in Plate XIII.

The character of these deposits is well shown in the north bank of Matanuska River 0.9 mile above Moose Creek. At this point the bluff, 200 feet high, is composed of interbedded gravel and silt. The silt is yellow and rather coarse. The gravel occurs in bands, lenses, and pockets irregularly distributed. It is predominantly of rather fine grain (less than 2-inch pebbles), although parts are coarse, with abundant 6 -inch cobbles and bowlders up to 2 feet in diameter. The material is all stratified and is in general well sorted. The pebbles represent a great variety of material. Granitic rocks predominate, but sandstone, shale, and a variety of fine-grained basic rocks are abundant. Much of the coarser gravel occupies channels in the sands. This gravel deposit is shown in Plate XIII, $B$.

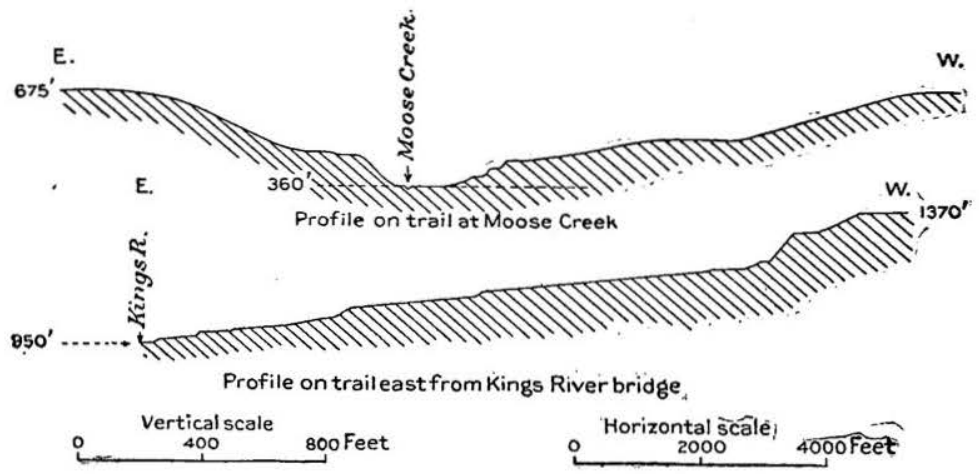

FrguRE 11.-Diagram of terraces on Moose Creek and on Kings River.

Gravel-covered terraces of somewhat different type were seen at higher elevations. Where the valley of Moose Creek comes out from the high mountains there are gravel benches up to an elevation of about 2,200 feet. Similar benches are seen at about the same altitude where Granite Creek emerges from the mountains. On the west side of Kings River, at a point about 2 miles north of the bridge, well-developed benches were observed at an elevation of 1,800 feet. They occur opposite the coal camp at an elevation of about 1,500 feet and on the east side of the creek at an elevation of about 1,700 feet. Broad gravel-covered flats at an elevation of about 1,600 feet were seen on both sides of Chickaloon River about a mile above Boulder Creek.

The significant fact in the distribution of these high-level terraces is that they are apparently restricted to the vicinity of the tributaries 


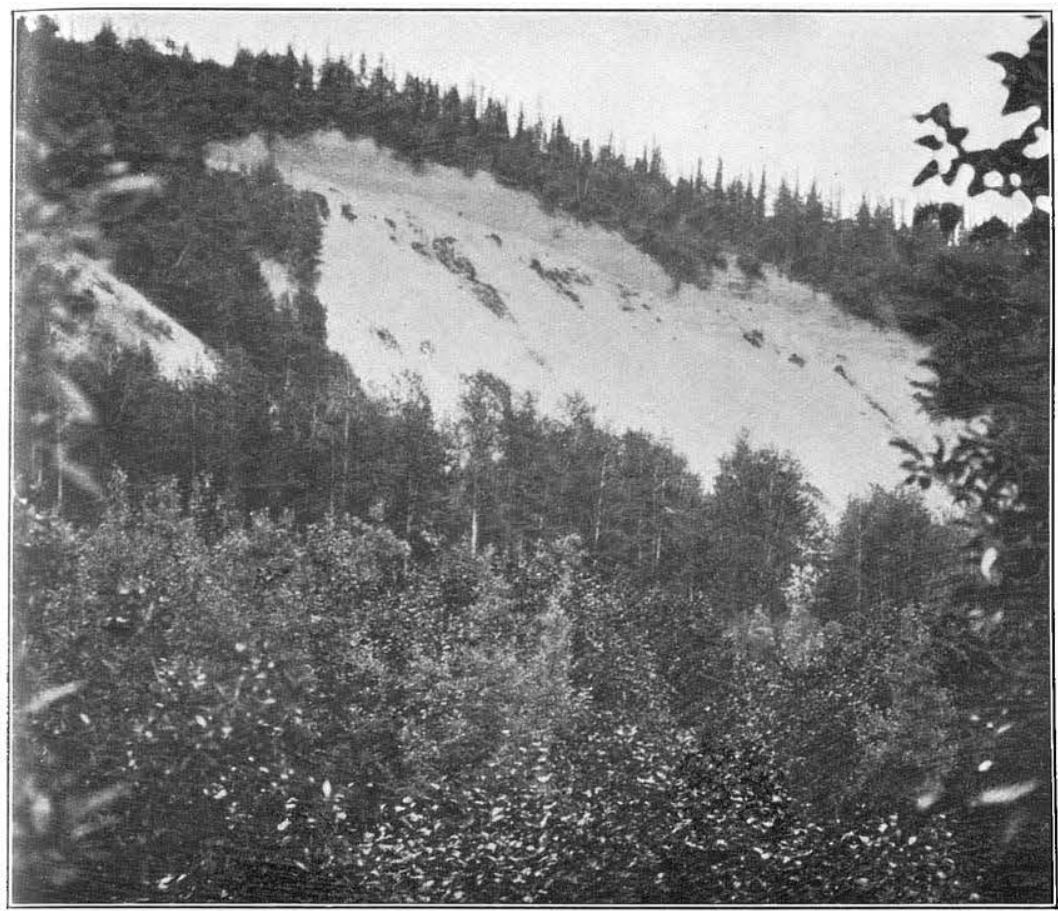

A. STRATIFIED GRAVELS ON EAST BANK OF KINGS RIVER NEAR LOWER BRIDGE.

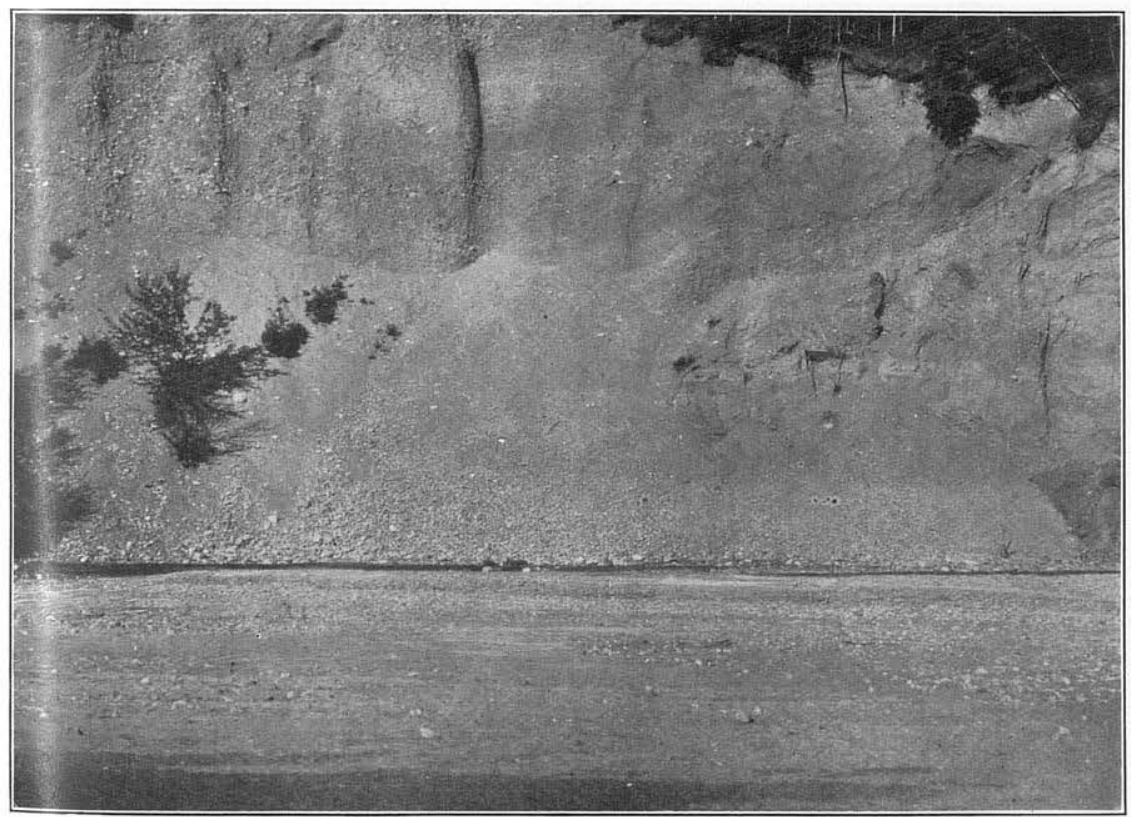

B. GRAVEL CLIFFS ON NORTH BANK OF MATANUSKA RIVER 1 MILE ABOVE MOOSE CREEK. 

of the Matanuska and were not seen at other points. It is believed that they were laid down in the ponded waters of these tributaries at times when the main Matanuska Glacier stood across the mouths of the tributary valleys.

\section{ALLUVIUM.}

Alluvial deposits are well developed on all the larger streams and on such of the smaller ones as do not have steep grade over continuous exposures of rock. The flats and gravel bars along the whole course of the Matanuska constitute one of the striking features of the geology of this region. The high degree of the development of these deposits is caused by the fact that the Matanuska is a heavily overloaded glacial stream whose flow, owing to the intermittent and varying supply, is very irregular. The Matanuska and its tributaries freeze every winter and tend to seek new courses when the spring thaws come. The run-off during the early summer months is much greater than at any other time of the year. The streams have their sources in large part at the ends of glaciers and are consequently loaded with detritus from the very start. They flow for the most part over unconsolidated deposits and have steep grades. They are consequently choked with sediment at all times, and whenever the water falls they begin to aggrade their beds.

The gulches traversing the lower and gentler slopes between Moose Creek and the ridge north of it show evidence of an apparently unusual recent stream activity. The streams, which are small even in the last half of June, when much snow remains on their headwaters and melting is rapid, occupy each a trench in a wide gravel and bowlder-strewn course through the brush and timber. This course is typically 100 feet wide, and in cross section its surface is flat or slightly convex. The stream occupies a shallow, usually indefinite, and random channel. The sides of the course are strewn with bowlders 5 to 10 feet in diameter, lodged among living and recently fallen trees. The first impression is that within three or four years on all the small streams there have been great floods that have cut wide courses through the timber, in which vegetation has not yet regained a foothold. It is, however, difficult to understand how any ordinary flood could handle material of such size and handle it as vigorously as is testified by the abraded, torn, and broken trees. If at the time of the floods the streams were frozen, or if their channels were filled with snow, as they usually are until late in the spring, these bowlders might have slid along on the steeply sloping ice or snow. The phenomena might well be the product of the regular early spring melting floods, the large bowlders being moved each year a little at a time. Similar conditions were observed on the 
tributaries of Eska and Granite creeks, on the creek north of the west end of Castle Mountain, and on many other creeks throughout the valley.

Many such accumulations of débris were seen on the lower courses of small streams heading in mountain gulches. The deposits are at and below the points where the gulches leave the very steep slopes and enter upon the comparatively flat gravel-covered floors of their master valleys. The débris appears not to have been distributed in typical alluvial fans, as by torrential streams, but rather as if it had been borne in a mass and suddenly dumped. It is therefore suggested that the hypothesis stated above might be modified so as to make snowslides or avalanches rather than melting floods the agents which carried the débris out of the high gulches. According to either explanation the bowlder accumulations are a result of the spring and early summer thaws.

\section{STRUCTURE.}

The dominant structural features of the Matanuska Valley bear a very close relation to the physiography and to the areal distribution of the different kinds of rock. The south front of the Talkeetna Mountains, which terminate on a remarkably straight line parallel to the general course of the Matanuska and about 5 or 6 miles north of it, is determined by a great fault or zone of faulting which was followed from one end to the other of the area mapped in detail and which probably extends for indeterminate distances farther in either direction. It is believed that this fault marks approximately the course of Little Susitna River below its point of emergence from the mountains, and it possibly extends east of Chickaloon River along the upper course of Boulder Creek.

The mountain and larger hills which interrupt the lowland area south of the great fault are occasioned by their structural features. Castle Mountain and Wishbone Hill are synclinal masses. The hills in the Young Creek region are partly monoclinal blocks of Upper Cretaceous sediments and partly intrusive bodies.

The best exposures of the great fault were seen on the headwaters of Young Creek and in the hills north of Castle Mountain. In the former locality two approximately parallel fault planes were observed at a distance of about half a mile apart. On the northern of these the granite is thrust upon the Tertiary arkose. At the southern fault the granite, which is overlain by the Tertiary arkose, is faulted against the Upper Cretaceous rocks (Pl. XVI, section $\mathrm{H}-\mathrm{H}^{\prime}$; Pl. XIV, $A$ and $B$ ). The observed relations at this point are shown in Plate $\mathrm{XVI}$, section $\mathrm{H}-\mathrm{H}^{\prime}$, and Plate VII, $B$ (p. 28). The fault where observed north of Castle Mountain brings both the granite and the Lower Jurassic volcanic rocks into contact with the Tertiary rocks 


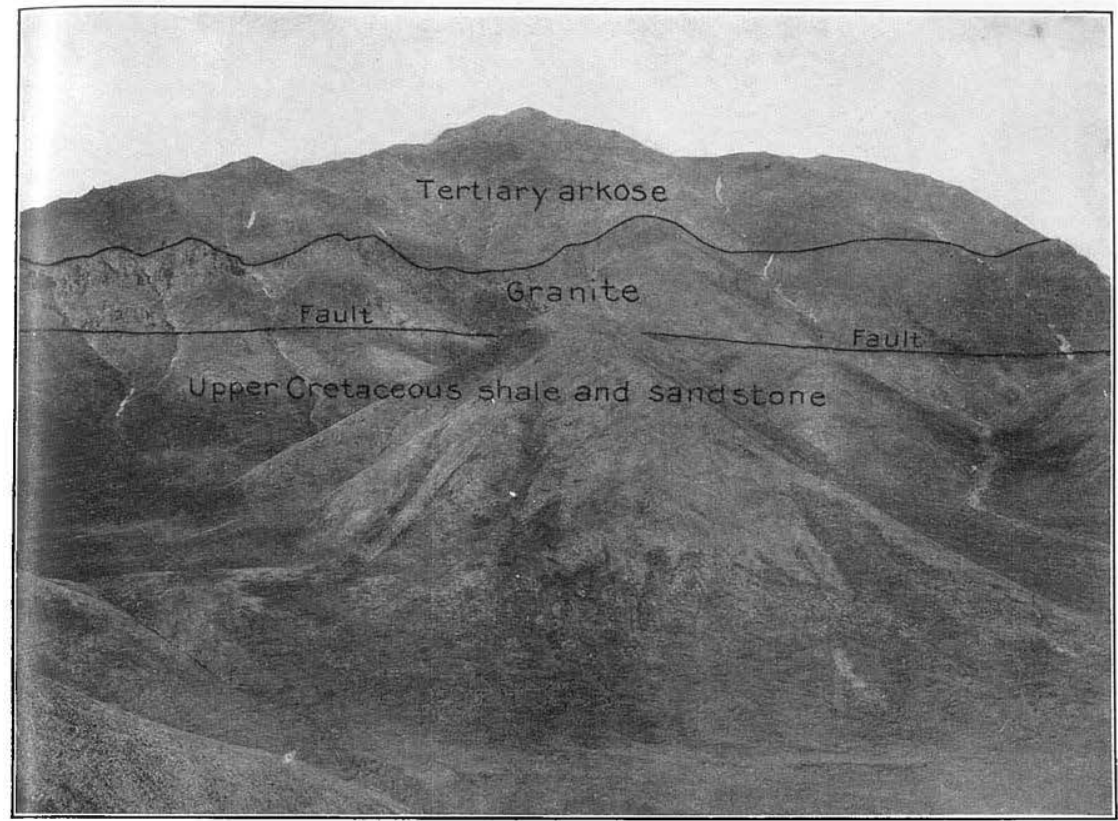

A. FAULT ON NORTH EDGE OF MATANUSKA VALLEY NEAR HEADWATERS OF YOUNG CREEK.

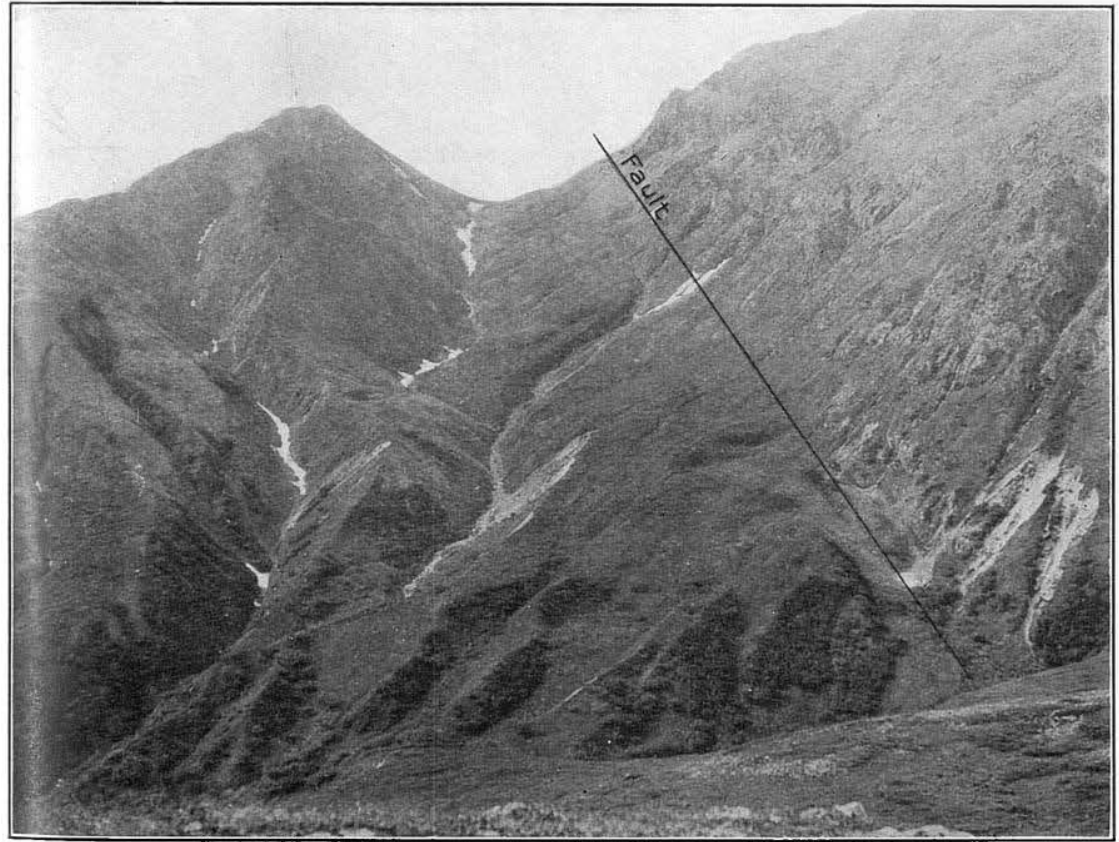

B. FAULT BETWEEN GRANITE (AT RIGHT) AND UPPER CRETACEOUS ROCKS (AT LEFT), ON CREEK THAT ENTERS KINGS RIVER FROM THE WEST $1 \frac{1}{4}$ MILES ABOVE COAL CAMP. 



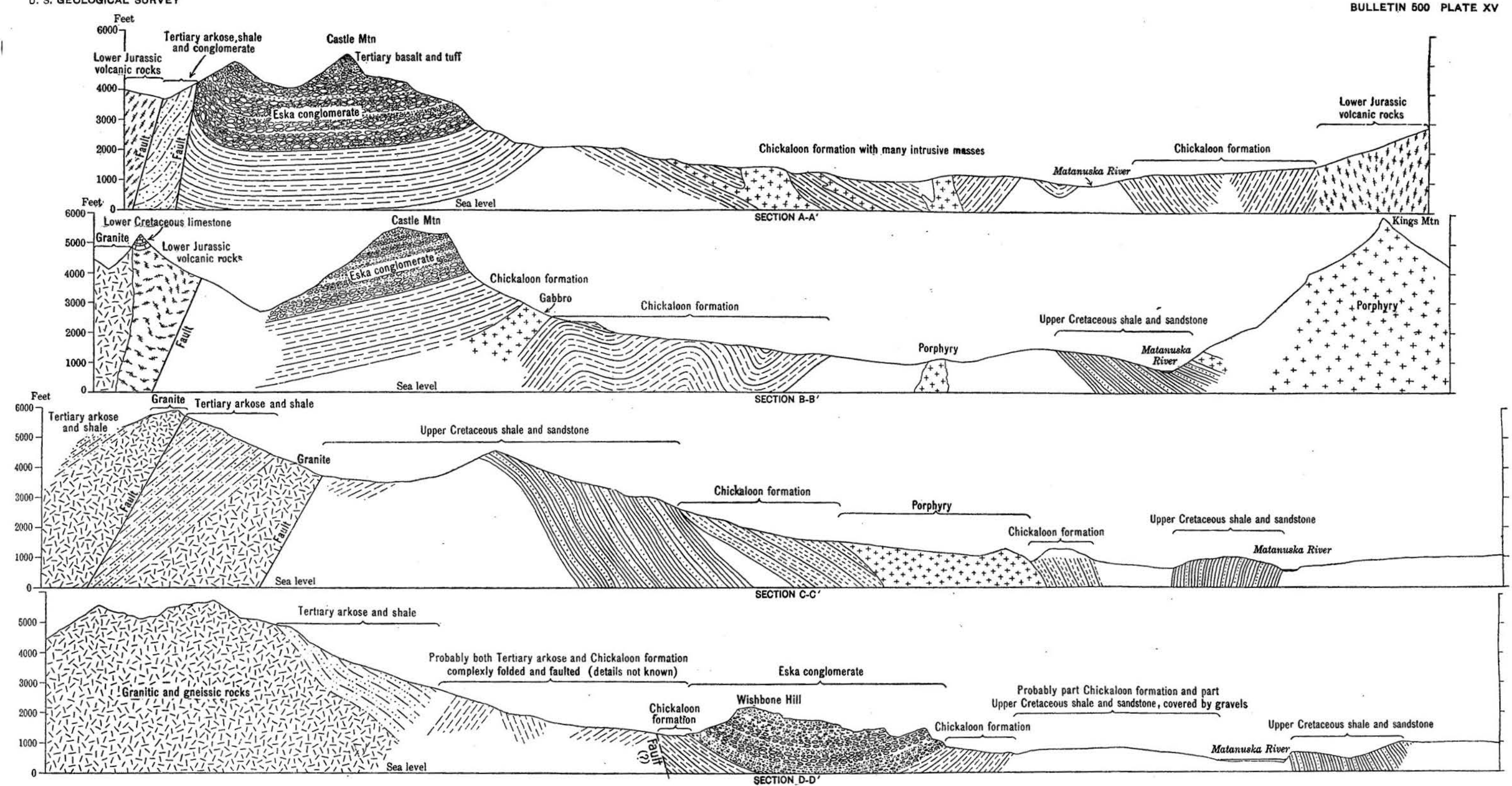

Tertiary arkose and shale

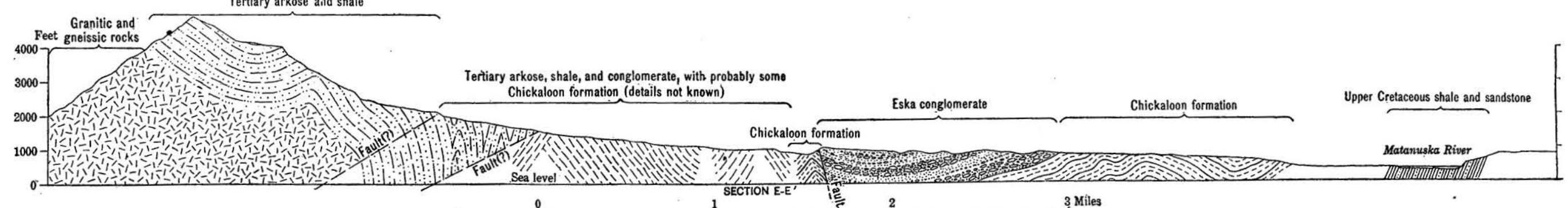

STRUCTURE SECTIONS IN LOWER MATANUSKA VALLEY. 


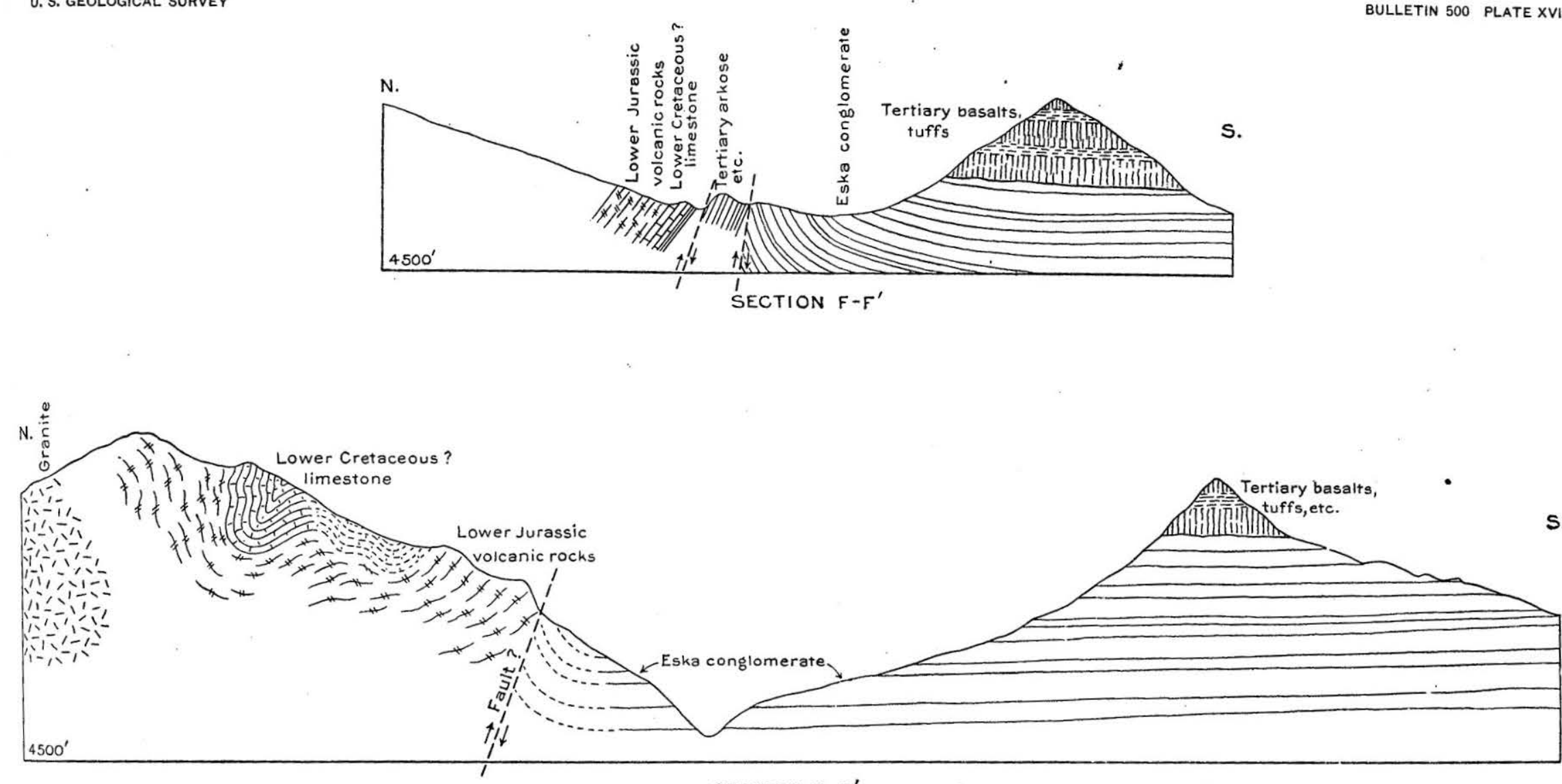

SECTION G-G'

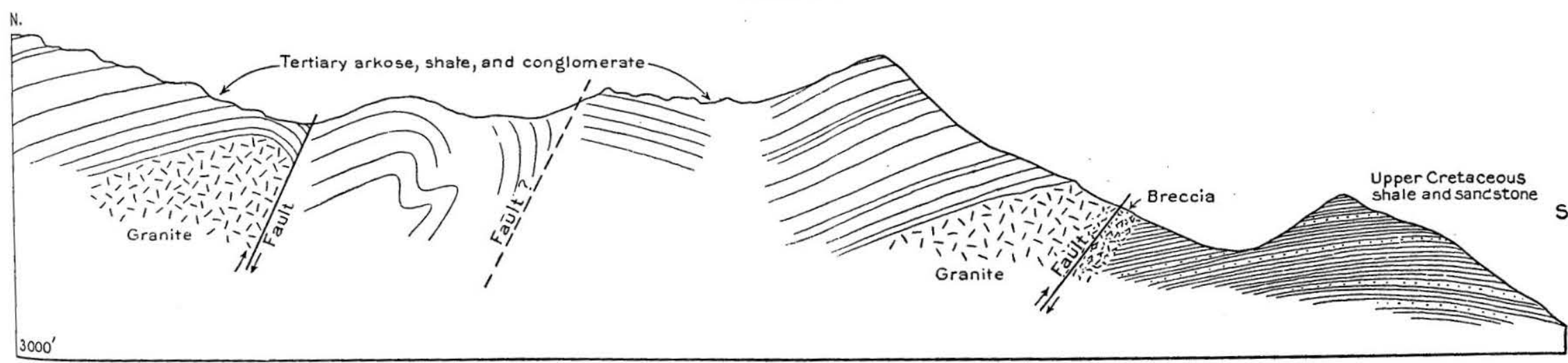

SECTION H-H'

$1000 \quad 0 \quad 2000 \quad 2000 \quad 3000$ Feet

STRUCTURE SECTIONS IN LOWER MATANUSKA VALLEY. 

(Pl. XV, section B-B'; Pl. XVI, section $\mathrm{G}-\mathrm{G}^{\prime}$ ) and farther east has brought the basal conglomerates of the Tertiary into contact with the much higher Eska conglomerate (PI. XV, section $\mathrm{A}-\mathrm{A}^{\prime}$; Pl. XVI, section $\mathbf{F}-\mathrm{F}^{\prime}$ ). The faulting throughout this zone is believed to be everywhere of reversed character, the fault planes dipping steeply to the northwest. The rocks north of the fault zone and close to it are in many places closely folded and in some places overturned, so that the axial planes dip to the north. The character of this overturned folding is shown in limestone beds represented on sections through Castle Mountain ( $\mathrm{Pl}$. XVI, section $\mathrm{G}-\mathrm{G}^{\prime}$ ) and also in the overturned anticline in the Tertiary rocks shown in Plate XVI, section $\mathrm{H}-\mathrm{H}^{\prime}$, and Plate VII, $B$ (p. 28).

At many places the rocks on each side of the major fault plane are much fractured and crushed through a zone several hundred feet wide. The granite has as a rule been severely shattered for a considerable distance from the contact. It is very much altered and epidote, chlorite, and other minerals are developed. To a slight extent it has received a gneissoid texture by the crushing into parallelism of some of its constituent minerals.

The granitic rocks and the Tertiary arkoses are in contact along the western half of the northern limits of the area. The relations are of two kinds. Around Moose Creek there is no good evidence that they are other than those of normal deposition of the beds of the arkose series upon the granites and gneissic rocks. The basement rocks at this locality include, besides some folded and sheared, thoroughly gneissic and schistose rocks which are intruded by granitic rocks, also granites of gneissoid habit which have been subjected to crushing forces. The more metamorphosed rocks are dominant near the contact; the merely gneissoid granites are more abundant away from the contact. This relation might be interpreted to mean that deformation had been largely confined to and accentuated along the contact of Tertiary rocks and granite. However, it seems certain that the metamorphic facies were developed and were injected by the granitic rocks prior to the arkose epoch and that the resulting complex became the basement for the deposition of the arkose. Because of the facts that the sedimentary series is arkosic and that the granitic rocks, gneisses, and schists are represented by pebbles in the conglomeratic members of the arkose series it is fairly certain that the arkose was derived from and deposited upon the granites, gneisses, and other rocks. The cataclastically developed gneissoid textures, on the other hand, seem to be significant of post-Tertiary deformation, for the granites are similarly gneissoid at other localities where they are faulted against the Tertiary sediments.

Between the arkose and the granite on Eska Creek there is a severely crushed fault zone which shows many planes of movement, 
some in the granites and some in the sedimentary rocks. Masses of both rocks are mixed in irregular alternation within the zone. The arkose is greatly indurated and resembles the ignieous rock. The granite is badly fractured and contains seams of epidote, quartz, and calcite. On the west of Granite Creek the relations are as on Eska Creek. This fault zone extends eastward from Eska Creek across Sheep Valley. There the granite not only occurs above and north of parts of the arkose, being faulted against it, as just described, but also lies below the arkose, as on Moose Creek, being the basement upon which it was deposited.

The approximately linear front of the northern edge of the Chugach Mountains, which lies about parallel to the front of the Talkeetna Mountains, suggests that the south wall of the Matanuska Valley, like its north wall, is determined by faulting. Unfortunately not enough observations were made south of the river to establish this point fully, and the linear character of the mountain front may be due entirely to truncation of the spurs by glacial erosion.

The general character of the structure of the valley is indicated in the sections on Plate XV. The sedimentary rocks have been strongly folded, so that steep dips and complex structures are present throughout most of the area. At some places there is a continued uniform dip for considerable distances, but it is not known whether this condition means simple monoclinal structure or a repetition of parallel fault blocks. At other places there are frequent reversals of dip, but this again may be either simple folding or more complex faulting. In each of these cases the lack of definite knowledge concerning the type. of structure is due to the absence of recognized characteristic strata from whose distribution the structural details could be inferred.

In two areas within the field the type of structure is known with a fair degree of certainty. These areas are those occupied by the conglomerate in the vicinity of Castle Mountain and of Wishbone Hill. The clearly defined contacts of the conglomerate with the adjacent rocks, as well as the various individual beds of conglomerate, here make it possible to determine the actual structural details.

The west end of Castle Mountain (see section B-B', Pl. XV) is a monoclinal block having a dip of about $6^{\circ}$ to $20^{\circ} \mathrm{NE}$. The east end, as is shown in section $\mathbf{A}-\mathrm{A}^{\prime}$, Plate $\mathrm{XV}$, is a syncline having a broad southern limb on which the dips range from $10^{\circ}$ to $20^{\circ} \mathrm{N}$. and a narrow, sharply upturned northern limb with dips of $60^{\circ}$ to $90^{\circ}$. Possibly the northern limb of this syncline is cut off in the western part of the mountain by a fault, or, on the other hand, the structure may be dominantly monoclinal with local upturning of the strata along the fault in the eastern part of the mountain but not in the western part. 
Wishbone Hill is in general structurally similar to Castle Mountain. The east end, as is shown in section $\mathrm{D}^{-\mathrm{D}^{\prime}}$, Plate $\mathrm{XV}$, is a syncline pitching sharply toward the west. The west end is likewise synclinal, but the northern limb of the syncline has been cut by a fault in the west end of the hill and in the valley of Moose Creek, as is shown in section $\mathrm{E}-\mathrm{E}^{\prime}$, Plate $\mathrm{XV}$, so that the conglomerate mass, as exposed on Moose Creek, shows dominant northward dip and would, but for a few exposures showing gentle southward dip, appear to be a monoclinal block.

The points of dissimilarity between Castle Mountain and Wishbone Hill are that in Castle Mountain the entire northern edge is bounded by a fault which has brought the arkosic rocks beneath the coal into contact with the conglomerate above the coal, while in Wishbone Hill the fault is possibly absent at the east end of the hill, so that the coal-bearing rocks encircle the end of the conglomerate mass, and at the west end of the hill the fault is not of sufficient magnitude to bring more than the coal-bearing rocks into contact with the conglomerate. The syncline at the east end of Castle Mountain pitches toward the east; that at the east end of Wishbone Hill pitches toward the west.

In the area south of the great fault between Granite Creek and Young Creek, occupied by Upper Cretaceous shales and sandstones, the structure probably departs only slightly from monoclinal. The dips are southeast, fluctuating between $30^{\circ}$ and $60^{\circ}$. On the east and north of this area the structures are more complex in the vicinity of the great fault and of the numerous large intrusive masses.

Where the Upper Cretaceous rocks are exposed along Matanuska River they are broken by a number of faults and are considerably more crumpled and shattered than at other localities. Unfortunately the cliffs are inaccessible for close study, so that the true character of the deformation and its structural significance are not known. It would seem, however, that the course of the river is along some structurally important line. The upper part of Kings River also may be on such a line, for it marks an eastern limit of the Upper Cretaceous rocks and the western limit of both the Lower Jurassic volcanic rocks and of one area of the Chickaloon formation.

\section{MINERAL RESOURCES.}

COAL.

AREAL DISTRIBUTION.

The coal of the Matanuska Valley occurs in several isolated fields, only part of which are included in the area here described. Three of these coal areas lie partly within the area described in this report. Of these the Chickaloon field is situated mostly in the lower part of 
the valley of Chickaloon River but extends west as far as Kings River, south across the Matanuska into the valley of Coal Creek, and possibly east beyond the Chickaloon Valley. The Eska-Moose field, which is second in area and importance, extends from the valley of Eska Creek west as far as Moose Creek and possibly into the gravelcovered area beyond it. The Young Creek field is intermediate in geographic position between the Chickaloon and Eska-Moose fields, being situated in the upper part of the valley of Young (Little Kings) Creek.

The areal extent of the assemblage of rocks which carry the coal is indicated on Plates V and XVIII (in pocket). The areas indicated as coal-bearing are those which may carry coal as distinguished from the areas (represented by other patterns on the map) which are known not to carry coal. The areas of the "coal-bearing rocks" can not be assumed to be underlain wholly by beds of coal of workable character and thickness. Moreover, parts of these areas may have no coal under them. The lack of knowledge as to the exact stratigraphic position of the coal beds, the uncertainty as to what stratigraphic parts of the "coal-bearing rocks" are represented by the several surface outcrops, and the concealment of the rocks by gravels over broad areas make the precise areal distribution of the coal a problem which can be solved only by drilling or other underground exploration.

The areas of the tracts which it is believed may contain workable coal are indicated in the subjoined tables. The first of these tables shows the areas known to be occupied by the "coal-bearing rocks," as defined above, and by the conglomerates and other beds which overlie them. The second table shows the areas which may also be underlain by these rocks but in which, because of concealment by gravels or of other lack of definite information, there is a possibility that other formations may be present. These estimates are provisional and are subject to modification, perhaps considerable, when the region is more thoroughly prospected.

Areas of supposed coal-bearing rocks.

Square miles.

Valleys of Chickaloon and Kings rivers.

South of Matanuska River between Kings Mountain and eastern edge of area shown on Plate V (in pocket)................. 8

Valley of Young Creek................................ 3

Valleys of Moose and Eska creeks ........................ 19

Areas of possible extensions of the supposed coal-bearing rocks.

Lower parts of valleys of Kings and Granite creeks ................ 8

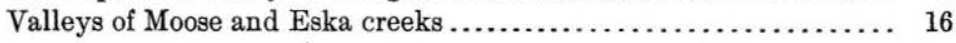




\section{STRATIGRAPHIC OCCURRENCE.}

The coal beds of the part of the Matanuska Valley here under discussion are all known to be of Tertiary age and to agree approximately in general stratigraphic position with the coal of the Kenai formation on Cook Inlet. They all occur within the Chickaloon formation, which is the middle local division of the Tertiary rocks as grouped in this report. Their exact position within this formation has not been determined, but they seem to be in general distributed throughout the greater part of its thickness. Nothing definite is known as to the persistence of individual beds or of groups of beds.

\section{DESCRIPTION OF BEDS.}

The following pages contain measured sections of all the coal beds which were accessible either in natural exposures or in prospect openings or tunnels. The location of the sections is shown by the numbers, which correspond to those on Plate XVIII (in pocket). No attempt has been made to correlate the beds, as the complex structure, the abrupt changes in thickness, and the fact that most of the beds have not been traced from point to point make correlation impossible. The sections are arranged in order from east to west.

\section{Sections of coal beds in lower Matanuska Valley.}

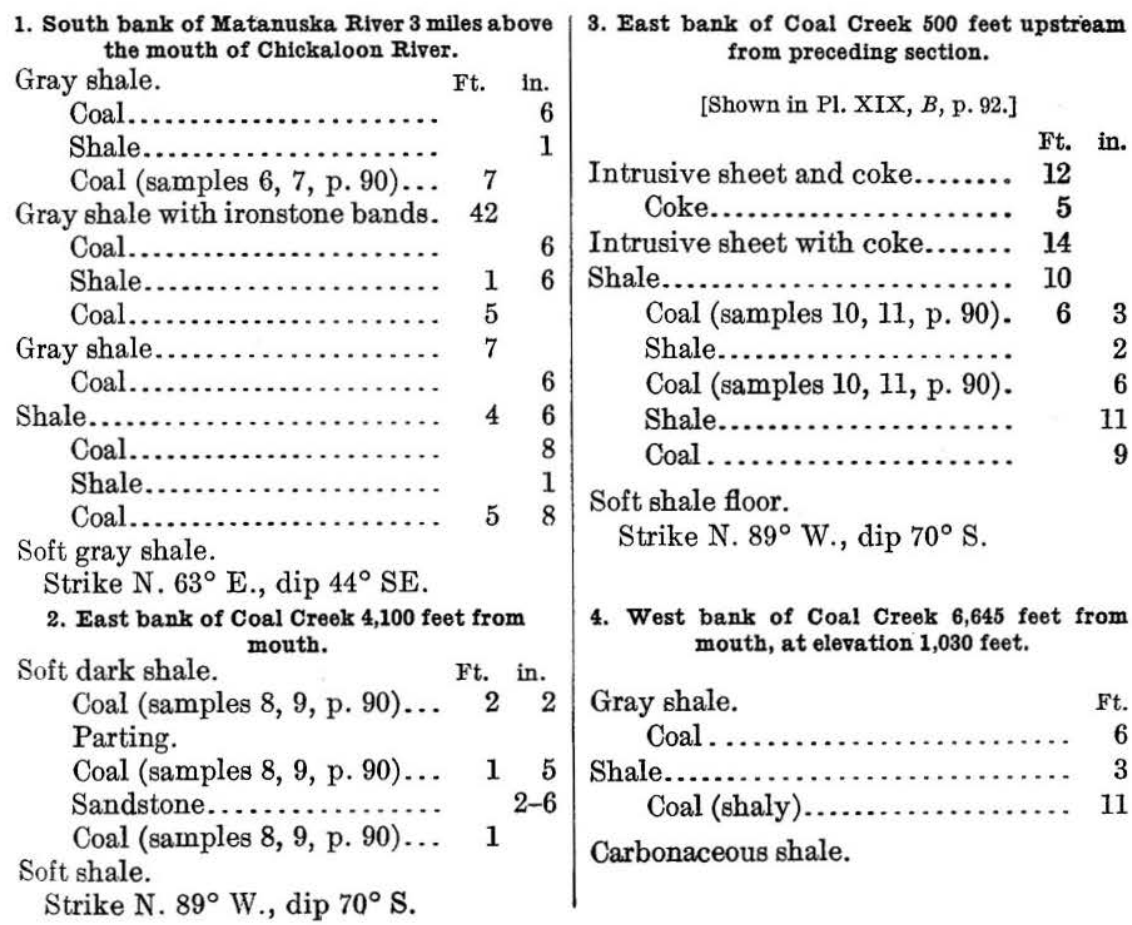


Sections of coal beds in lower Matanuska Valley-Continued.

5. West bank of Coal Creek 6,865 feet from

Gray shale.

Coal.

Shale. mouth.

Coal .....................

Shale with some coal ...... Gray shale.

Strike N. $77^{\circ}$ E., dip $60^{\circ} \mathrm{NW}$.

6. East bank of Coal Creek 7,700 feet from mouth, at elevation 1,055 feet.

Gray shale.

Coal. Ft. in.

Shale. 47

Coal ......................

Shale.

Coal .....................

Shale.

Coal ....................

Shale.

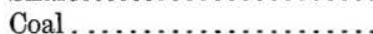

Shale.

Coal .....................

Carbonaceous shale.

Shale and coal altered by dike..

Strike N. $67^{\circ}$ E., dip $65^{\circ} \mathrm{NW}$.

7. Bend of Chickaloon River half a mile above Chickaloon.

[Shown in Pl. XIX, A, p. 92.]

Black shale.

Coal

Coal, bony

Shale.

Coal.

Shale, black.

Coal.

Concealed
7. Bend of Chickaloon River half a mile above Chickaloon-Continued.

Shale

Coal.

Shale.................... 8

Coal..................... 10

Shale.................... 6

Coal....................... $2 \quad 3$

Shale and sandstone (horse)..... 10

Coal....................... 6

Shale with coal stringers.... 1

Coal...................... 10

Shale.................... 4

Coal...................... 2

Shale................... 1

Coal....................... 6

Shale.................... 1

Coal..................... $4 \quad 4$

Shale.

8. Tunnel A, Chickaloon.

Coal.

Ft. in.

Bone and coal ............. 9

Coal...................... $14 \quad 8$

Shale....................... 12

Coal..................... 8

Bone and shale ............ 5

Coal...................... 8

Shale........................ 12

Coal....................... 3

Shale and sandstone........... 77

Strike N. $43^{\circ} \mathrm{W}$., dip $65^{\circ}$.

9. Tunnel A, Chickaloon.

Coal in face............... Ft. $\frac{\text { in. }}{11}$

Shale....................... $5 \quad 5$

Coal...................... 14

Bony coal................. 1

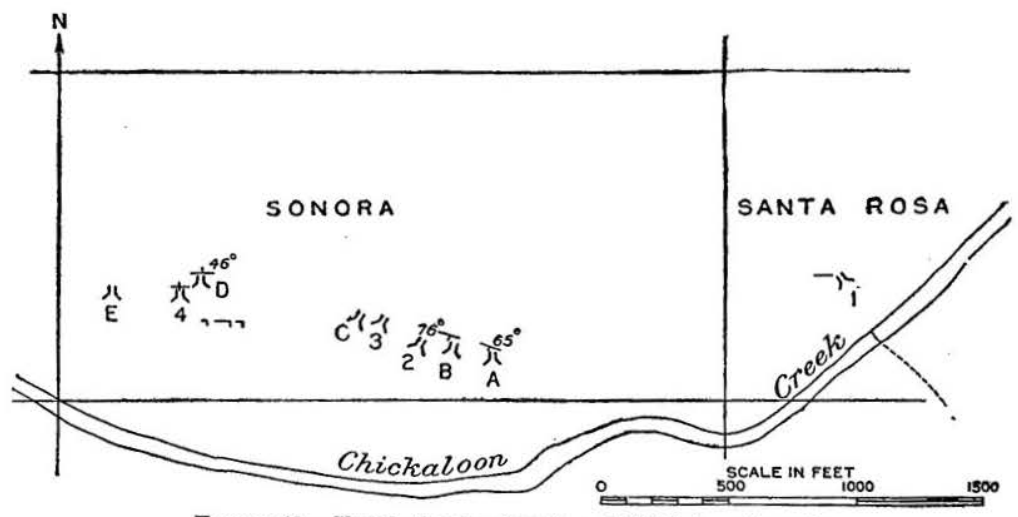

FIGURE 12.-Sketch showing location of Chickaloon tunnels. 
Sections of coal beds in lower Matanuska Valley-Continued.

9. Tunnel A, Chickaloon-Continued.

Coal................. ${ }_{2}^{\text {t. }}{ }_{1}^{\text {in. }}$

Coal ${ }^{1}$

Shale ${ }^{1}$

Coal ${ }^{1}$

Shale.

Coal.

Shale.

Coal.

Shale

Coal.

Shale.

Coal.

Bone.

Shale.

Coal.

Shale.

Coal.

Shale.

Coal.

Shale.

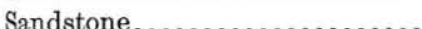

Shale.

Coal.

Shale.

Coal.

Shale.

Coal.

Shale.

Shale.

Sandstone.

Shale (at entrance of tunnel)

Shale (outside of tunnel)........

Coal.

Bony coal.

Shale.

Bone.

Shale.

Talus slope.

10. Tunnel B, Chickaloon.

Shale.

Coal.

Bone.

Coal.

..................

Coal....................

Bone................... 1

Coal.

Streak of bone.

Coal.

Sandstone.
10. Tunnel B, Chickaloon-Continued.

Shaly coal............. Ft. in.

Sandstone.................. 16

Bony coal................. 25

Sandstone................. 11

Coal, with streaks of bone.. 4

Sandstone................... 131

Coal...................... 24

Sandstone................. 95

Crusted shaly coal ........ 3

Coal..................... 36

Bone................... 1

Shale..................... 6

Coal..................... 10

Bone................... 3

Coal...................... 4

Sheared shale................ 2

Coal................... 3

Bone..................... 7

Sandstone and shale........... 65

Strike N. $48^{\circ}$ W., dip $76^{\circ} \mathrm{SW}$.

11. Tunnel B, Chickaloon.

Shale.

Shale with coal and bony beds.. $\quad 5 \quad 6$

Coal.................... 16

Shale................. 3

Coal................... $4 \quad 3$

Shale................ 2

Coal.................... 11

Irregular shale mass ........ $\quad 5$

Coal.................... $\quad 11$

Shale................. 8

Coal.................... 11

Shale................. 4

Coal.................... 16

Shale with many coaly beds $\quad 11$

Coal.................... $4 \quad 2$

Shale with coal and bone partings............. 7

Shale.................... 9

Coal................... 7

Shale.................. 27

Alternating coal and shale.. $\quad 3 \quad 2$

Coal................... $3 \quad 10$

Shale................... 121

Bony nodules.............. 1

Coal................... 5

Shale..................... $8 \quad 9$

Shale with coaly streaks.......... 110

Coal................... 7

Shale................. 4

1 Crosscut goes south on these beds. 
Sections of coal beds in lower Matanuska Valley-Continued.

11. Tunnel B, Chickaloon-Continued.

Coal.

Shale.

Coal.

Shale

Coal.

Shale.

Coal with bony bands.

Bone and shale with some coal..................

Shale.

Coal and bone ${ }^{1}$. . . ................

Shale and bone ${ }^{1} \ldots \ldots . . . . .$.

Coal ${ }^{1}$

Shale.

Coaly shale.

Coal with some shaly streaks.

Shale (entrance of tunnel) ......

Strike N. $48^{\circ}$ W., dip $67^{\circ} \mathrm{SW}$.

12. Tunnel No. 2, Chickaloon.

Hard shale.

Bone.

Coal ${ }^{2} 3$

Bone ${ }^{2}$

Coal 23

Bone ${ }^{2}$

Coal 23

Bony coal ${ }^{2}$

Shale and bone

Coal ${ }^{2} 3$

Coal, with some bone ${ }^{2} \ldots$.

Coal 23

Bone

Hard shale.

Coal.......................... 6

Shale (at mouth of tunnel)..... 20

Dip almost vertical toward mouth of tunnel.

13. Tunnel No. 2, Chickaloon.

Coal.

Shale.

Coal $^{4}$.

Bony coal.

Shale.

Coal.

$\begin{array}{rr}\text { Ft. } & \text { in. } \\ 2 & 4 \\ 1 & 6 \\ & 3 \\ 5 & 6 \\ & 9 \\ & 5 \\ 2 & 4 \\ & \\ 1 & 10 \\ 1 & 10 \\ & 11 \\ & 9 \\ 2 & 10 \\ 11 & 10 \\ & 9 \\ 1 & 5 \\ 33 & \\ & \end{array}$

Ft. in

5

5

24

$1 \quad 11$

11

$\begin{array}{rr} & 6 \\ 2 \quad 8\end{array}$

110

25

2

13. Tunnel No. 2, Chjckaloon-Continued.

Shale $\ldots \ldots \ldots \ldots \ldots \ldots \ldots$ Ft. in

Shale and bony coal........... 13

Coal ${ }^{5}$................... 34

Bony coal and shale....... 17

Shale................... 18

Bony coal ${ }^{6} \ldots \ldots \ldots \ldots \ldots \ldots .1$

$\mathrm{Coal}^{6}$................ 29

Bony coal ${ }^{6} \ldots \ldots \ldots \ldots \ldots \ldots . \quad 10$

Shale................... 14

Timbering.................. 11

14. Tunnel No. 3, Chickaloon.

Shale.................... 10

Coal.................... 14

Shale................. 6

Bone.................. 6

Coal ${ }^{7} \ldots \ldots \ldots \ldots \ldots \ldots \ldots \ldots \ldots$

Shale with coal streaks.......... $4 \quad 6$

Strike N. $81^{\circ}$ W., dip $72^{\circ}, 75^{\circ}, 83^{\circ} \mathrm{NE}$.

15. Tunnel No. 3, Chickaloon.

Coal.

1

Shale.................. 3

Coal.................... 39

Shale................. 2

Coal ${ }^{8} \ldots \ldots \ldots \ldots \ldots \ldots \ldots, 4$

Shale.................... 16

$\mathrm{Coal}^{9} \ldots \ldots \ldots \ldots \ldots \ldots \ldots \ldots, \quad 19$

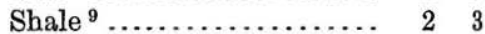

Coal ${ }^{9}$.................... 110

Shale with coaly streaks.... 18

Shale.................... 43

Coal (crosscut goes south)... $3 \quad 3 \quad 4$

Shale.................. 1

Coal..................... 10

Shale................... 5

Timbered (entrance of tunnel).. 16

16. Tunnel C, Chicisaloon. Ft. in.

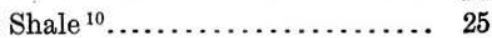

Coal.................... 9

Shale.................. $4 \pm$

Coal....................... 26

Coal, more or less shaly..... $3 \quad 3$

7 Shale...................... 96

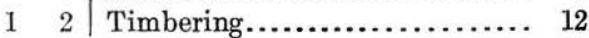

${ }_{1}$ Crosscut goes S. $77^{\circ} \mathrm{W}$. on these beds to tunnel 2. (See note 4.)

2 Included in sample 1, p. 90.

${ }^{3}$ Included in sample 2, p. 90.

4 Crosscut goes south on this bed.

${ }^{5}$ Crosscut goes north on this bed to tunnel B. (See note 1.)

${ }^{6}$ Crosscut goes south to raise.

${ }^{7}$ Included in sample 4, p. 90.

8 Measurement made on floor of tunnel, but coal is cut off entirely at the roof hy a fault.

9 The crosscut going south to raise from tunnel 2 should be on this bed.

10 The 3 foot 4 inch coal in crosscut going south from tunnel 3 should be the second bed beyond the present face of this tunnel. 
Sections of coal beds in lower Matanuska Valley-Continued.

17. Tunnel D, Chickaloon.

Coal. $\begin{array}{ll} & \\ & \end{array}$

Strike N. $80^{\circ} \mathrm{W}$., dip $64^{\circ} \mathrm{NE}$.

18. Tunnel E, Chickaloon.

Coal.

Bone.

Coal.

Bone.

Coal.

Crushed shale and coal......

Coal.

Sandstone and shale.

19. Tunnel No. 5, Chickaloon. Shale.

Coal ${ }^{1}$

Shale.

Bony coal

Shale.

Coal ${ }^{1}$

Shale.......................

Strike N. $89^{\circ}$ E., $\operatorname{dip} 51^{\circ} \mathrm{N}$.

20. Tunnel F, Chickaloon.

Coal.

Shale

Bone and coal.

Coal

Shale.

Coal.

Bone.

Coal.

Shale.

Coal.

Shale.

Coal

Shale (to cave-in).

Strike east and west, $\operatorname{dip} 70^{\circ} \mathrm{N}$

ข1. East bank of Kings River at bend below coal camp.

[Included in section on p. 47.]

Dark shale with ironstone nodules.

Coal.

Shale

Coal.

Parting.

Coal

Shale.

Coal......................

Shale.

Coal.

\begin{tabular}{rr|r} 
Ft. & in. \\
3 & 8 \\
17 & 6
\end{tabular}

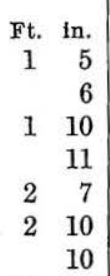

18

Ft. in. 10

$\begin{array}{ll}1 & 8\end{array}$

6

$\begin{array}{ll}1 & 8\end{array}$

10

$\begin{array}{ll}6 & 2\end{array}$

28

Ft. in.

13

3

15

8

$\begin{array}{rr} & 4 \\ & 2 \\ 2 & 5 \\ & 3 \\ 1 & \\ & 8 \\ & 10\end{array}$

7

ow coal

Ft. in. (1) 21. East.bank of Kings River at bend belov coal
camp-Continued.

Carbonaceous and concretionary

shale .................... 12

Shale with many thin coal streaks............... $7 \frac{1}{2}$

Coal..................... 8

Gray shale with ironstone nod-

ules, and sandstone......... 153

Shale.

Coal..................... 5

Shale................... 1

Coal..................... $6 \frac{1}{4}$

Shale................. $3 \frac{1}{3}$

Shale with small coal streaks and lenses............... 2

Coal..................... 8

Parting.

Coal...................... $\quad 11 \frac{1}{2}$

Shale crushed into small pieces and slickensided... 6

Coal...................... $2 \frac{1}{4}$

Shale.................... 42

Bright coal................ 8

Coked coal and baked shale.... $8 \pm$

Diabase sill.

Strike N. $15^{\circ}$ E., dip $31^{\circ} \mathrm{SE}$.

22. Tunnel on east bank of Kings River 100 yards above upper bridge.

Dense, impure coke........ $\quad 5$

Bony shale................. 1

Coal..................... 1

Shale................. 1

Coal.................... 8

Bone.................. 1

Coal..................... 12

Bony coal................ 9

Coal.................... $2 \quad 6$

Hard shale.

23. Open cut 10 feet south of preceding section.

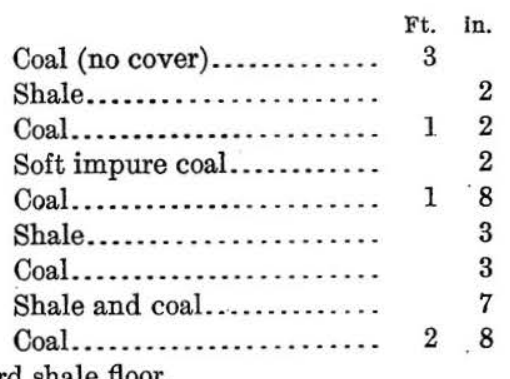

Hard shale floor.

$9949^{\circ}-$ Bull. $500-12--6$

Included in sample 5, p. 90. 
Sections of coal beds in lower Matanuska Valley-Continued.

24. Kings River at upper bridge, west side.

Bone and coal.

Shale.

Clean coal................. 17

Concealed short distance.

Crushed coal with lenses of

bone.................

Shale..................

Sandy shale..............

Coal.

Bone

Coal.

Coal.

Bone.

Coal.

Strike N. $15^{\circ} \mathrm{W}$., dip $42^{\circ} \mathrm{NE}$.

25. Opening on west bank of Kings Creek at upper bridge.

[On same bed as preceding section.]

Coal ${ }^{1}$. Ft. in.

Sandstone..............

Coal ${ }^{1}$.

Shale.

Coal.

Sandstone.

Bony coal ${ }^{1}$

Sandstone.

Coal ${ }^{1}$

Strike N. $15^{\circ}$ W., dip $42^{\circ} \mathrm{NE}$.

26. Gulch on northwest side of mountain 4 miles north of the mouth of Young Creek Shale. ("Red Mountain").

Coal (details obscure, total thickness estimated)..... $7 \pm$

Coal......................

Shale................ $\quad 1_{\frac{1}{2}}^{1}$

Coal ${ }^{2}$................... 1

Shale................. 1

Coal ${ }^{2} \ldots \ldots \ldots \ldots \ldots \ldots \ldots . . .6$

Shale................ $\quad 1 \frac{1}{2}$

Coal ${ }^{2} \ldots . . \ldots \ldots \ldots \ldots \ldots . .67$

Shale.................

Coal ${ }^{2} \ldots \ldots \ldots \ldots \ldots \ldots \ldots \ldots$. 4

Shale................. $\frac{1}{2}$

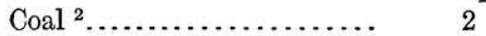

Shale.................

$\mathrm{Coal}^{2}$................. 2

Strike, on sandstone below, N. 67 E., $\operatorname{dip} 54^{\circ} \mathrm{SE}$.

1 Included in samples 12 and 13, p. 90. 2 Included in sample 1-1910, p. 90.
About 30 feet stratigraphically above section 26 is another coal bed at least 5 and possibly 10 feet thick, and again 30 feet higher and about 80 feet higher are coal beds largely obscured by talus.

27. West bank of Young Creek $3 \frac{1}{2}$ miles above mouth.

Shale.

Ft. in. $\mathrm{Coal}^{3}$ 1

Shale.................... 15

Coal.................... 6

Shale with sandstone bands.

Strike N. $15^{\circ}$ E. (magnetic), dip $20^{\circ} \mathrm{NW}$.

28. West bank of Eska Creek, at elevation 925 feet.

Shale and sandstone.

Ft. in

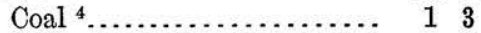

Shale................. 1

Coal ${ }^{4}$.................... 14

Shale................. 1

Coal, bony................ 1,3

Shale.................

Coal, bony............... 11

Shale................... 1

Coal with some shale and bone............... 26

Shale.................... 6

Coaly shale................. 2

Strike N. $57^{\circ}$ E., dip $44^{\circ} \mathrm{NW}$.

A more complete section in the same bed measures as follows:

29. West bank of Eska Creek, at elevation 825 feet.

Sandstone............ 15 in

Shale................... $2 \quad 6$

Coal. 7

Parting.

Coal.................. $\quad 5$

Parting.

Coal.................. 5

Parting.

Coal................... $1 \quad 6$

Coal with shaly streaks... 7

Coal................... $10 \frac{1}{2}$

Shale............... 1-21

Coal (a hard stony nodule was seen in this bed).. 11

Coaly shale.............. 15

Coal.................. 1

Shale................ 1

Coal................. $3 \frac{1}{2}$

Coaly shale.............. 3

${ }^{3}$ Included in sample 16, p. 90. 4 Included in sample 17, p. 90. 


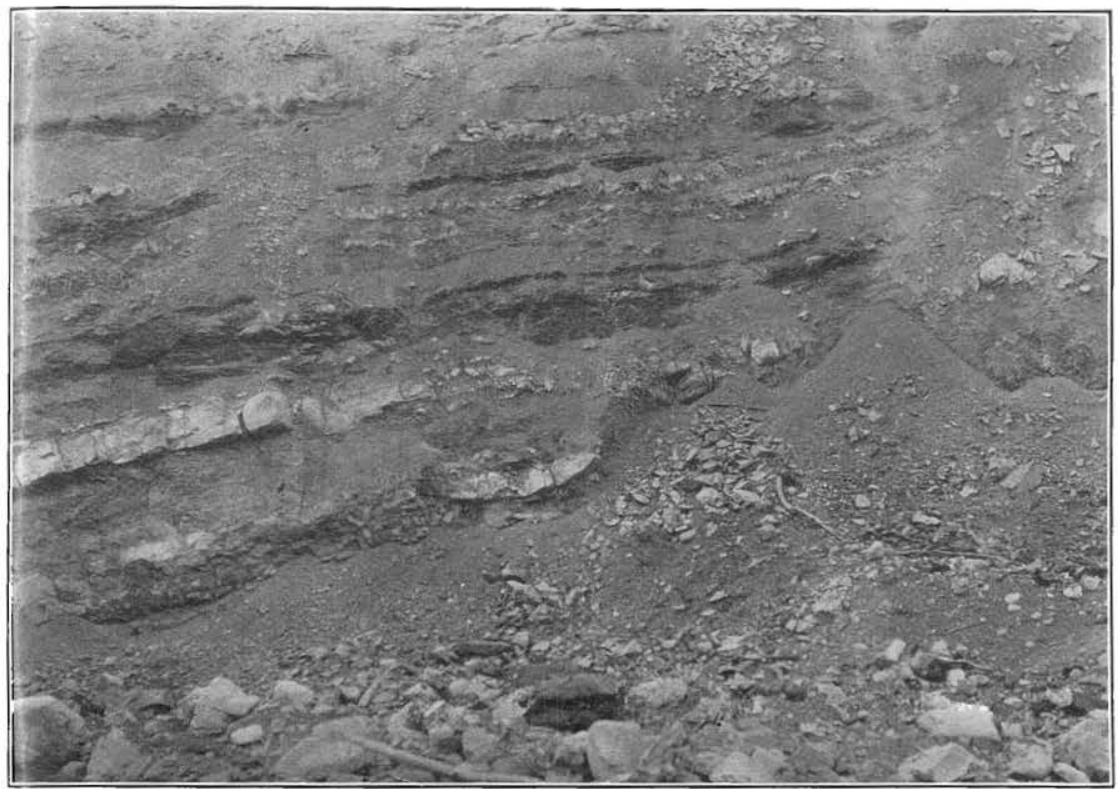

A. COAL BEDS IN WEST BANK OF ESKA CREEK 2.7 MILES NORTH OF MATANUSKA RIVER.

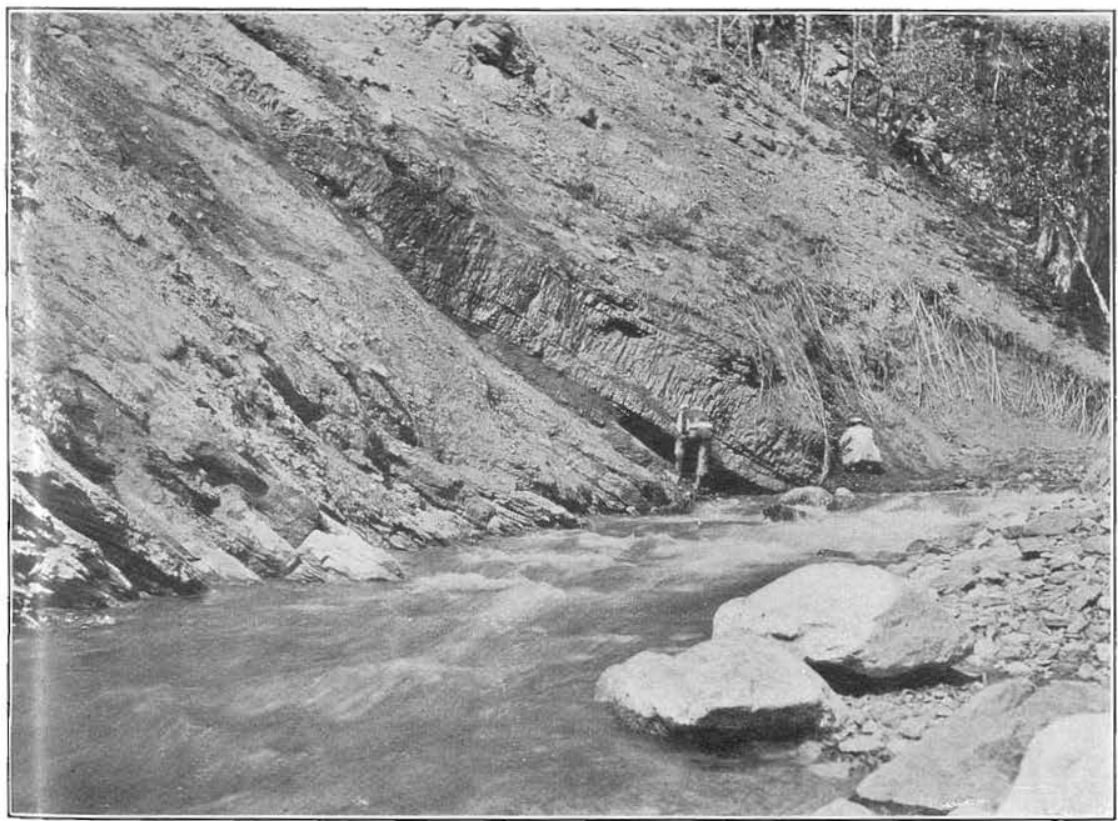

B. COAL BED IN WEST BANK OF ESKA CREEK 2.4 MILES NORTH OF MATANUSKA RIVER. 

Sections of coal beds in lower Matanuska Valley-Continued.

29. West bank of Eska Creek, at elevation 925 feet-Continued.

Shale

Ft. in.

Coal (a hard stony nodule was seen in this bed)...

Parting.

Coal

Shale.

Coal with several thin shaly beds. 1

Shale

Coaly shale

Coal with many thin shale bands.................

Coal (with silicified logs, especially at the top)... $\quad 1 \quad 2-4$

Shale. ...................... 24t

Major cleat S. $42^{\circ}$ E., dip $83^{\circ} \mathrm{SW}$., not well developed.

Strike N. $57^{\circ}$ E., dip $42^{\circ} \mathrm{NW}$.

30. West bank of Eska Creek about 300 feet upstream from preceding section.

Shale roof.

Coal ${ }^{1}$

Ft. in.

Shale. $3 \quad 3$

Coal. 3

Shale

Coal.

Shale.

Coal.

Shale.

Coal.

Soft black shale.

Dip northwest.

31. West bank of Eska Creek 3,600 feet below forks.

Shale. [Shown in Pl. XVII, B.]

Shale with thin coal beds.

Coal.................... 1

Coaly shale...............

Coal....................

Rusty shale..............

Coal....................

Parting.

Coal

Parting.

Coal.

Shale parting.

Coal.
31. West bank of Eska Creek 8,600 feet below forks-Continued.

Rusty shale. Ft. in.

Coal.................. . $4-6$

Shale............... $2 \frac{1}{2}$

Coall................... 5

Sandstone............. $\quad 1-2$

Bony shale............. $2 \frac{1}{2}$

Coal.................. $3 \frac{1}{2}$

Shale and arkose.

Strike west, $\operatorname{dip} 36^{\circ} \mathrm{N}$.

About 100 feet above is the following section:

32. West bank of Eska Creek 3,600 feet below forks.

Shale.

Concealed.

Coal.

Ft. in.

Shale.......................

Coal (clay-ironstone nodules in a $2 \frac{1}{2}$ to 5 inch layer near top)...............

Shale..................

$2 \quad 2$

Coal................... 11

Shale............... $2 \frac{1}{2}-3 \frac{1}{2}$

Shale with veins of coal. . 15

Coal................... 3

Shale with veins of coal. . $\quad 7$

Coal................... $6 \frac{1}{2}$

Shale parting.......... $\frac{1}{2}$

Coal.................. $8 \frac{1}{2}$

Shale.............. $\frac{1}{2}-1$

Coal................. $2 \frac{1}{2}$

Coaly shale........... 11

Shale.

Major cleat S. $30^{\circ}$ E., dip $90^{\circ}$. Minor cleat N. $53^{\circ}$ E., dip $50^{\circ} \mathrm{SE}$.

33. East bank of Eska Creek, at elevation 950 feet.

Shale.

Coaly shale............ 1

Sandstone............. $\quad 1_{\frac{1}{2}}$

Coaly shale............. $\quad 1_{\frac{1}{2}}$

Coal................... $\quad 1_{\frac{1}{2}}$

Shale................. 2

Coal ${ }^{2}$................... 28

Parting.

Coal with shaly bedding.... 1

Shale and arkose............... 22

Arkose..................... 7

1 Included in sample 18, p. 90.

2 Major cleat S. $43^{\circ}$ E., dip $88^{\circ} \mathrm{NE}$.; minor cleat not well developed. 
Sections of coal beds in lower Matanuska Valley-Continued.

33. East bank of Eska Creek, at elevation 950 feet-Continued.

Concretionary shale.

Coal and shale in minute beds.

Shale.

$\mathrm{Coal}^{1}$ (contains silicified log near top)

Parting.

Coal.

Parting.

Coal, with shaly bedding, consisting of a mat of leaves concealed..........

Strike N. $50^{\circ}$ E., dip $18^{\circ} \mathrm{SE}$.

34. Base of cliff on west bank of Eska Creek, at elevation 1,000 feet.

Shale, concretionary.

Black shale with coaly streaks.................

Coal.

Shale.

Ft. in.

410

Coal.

Shale

Coal.

Coal with thin shaly bands.

Shale.

Coal.

Shale.

Strike N. $62^{\circ}$ E., dip $35^{\circ} \mathrm{SE}$. Major cleat S. $48^{\circ}$ E., dip $84^{\circ} \mathrm{NE}$.

35. West bank of Eska Creek, at elevation $1,000+$ feet.

Sandstone (cliff)

Ft. in

Soft sandstone.

Shale with little coal..... 2

Concealed, mostly shale...... 80

Coal..................... 4

Shale.................. 1

Coal.

Shale.

Coal.

Shale, some coal, and ironstone concretions........

Coal with several shale beds..................

Shale with ironstone concretions....................

Coal (with shaly bedding in part and many thin shale partings)......... 13

Shale
35. West bank of Eska Creek, at elevation $1,000+$ feet-Continued.

Ironstone.................... Ft. in.

Shale..................... 3

Ironstone.................... 2

Shale..................... 5

Coal.................... 9

Shale with seams of coal.. 11

Coal...................... 2

Shale.................. $2 \frac{1}{2}$

Coal.................... 4

Shale.................. 2

Coal.................... $2 \quad 8$

Shale................ 7

Coal.................... 19

Shale with veins of coal. . 241

Coal.................... 1

Shale.................. 2

Coal containing clay-ironstone nodules.......... 5

Shale.................. $\quad 1 \frac{1}{2}$

Coal.................... 2

Shale................

Coal................... 3

Shale................. 2

Coal................... 1

Shale............... $1 \quad 10$

Shale with bands of coal. . $\quad 6$

Shale................ 6

Coal.................... 2

Shale with ironstone bands.... $14 \quad 6$

Ironstone................ 13

Shale................... $4 \quad 7$

Coal................... 1

Shale................... $5 \quad 9$

Coal.................. 8

Shale................... 6

Ironstone..................... $1 \quad 3$

Gray shale................ 15

Ironstone................... 2

Shale...................... 28

36. West bank of Eska Creek about 1,250 feet below forks.

Sandstone. Ft. in.

Shale................... $7 \quad 3$

Coal and shale............ 6

Coal..................... $3 \quad 6$

Shale with thin coaly streaks................ 1

Coal...................... 8

Shale with occasional $\begin{array}{llll}\text { streaks of coal ......... } & 2 & 8\end{array}$

Coal with many shale bands................ 1

1 Major cleat N. $42^{\circ}$ E., dip $76^{\circ} \mathrm{SW}$. 
Sections of coal beds in lower Matanuska Valley-Continued.

36. West bank of Eska Creek about 1,250 feet below forks-Continued.

Shale......................

Coal with many shale bands.................

Shale with occasional coal lenses....................

Ironstone nodules..............

Shale.

Bright coal (a nodule seen near top) ..............

Coal with many thin shaly bands ..................

Shale

Coal, somewhat shaly....

Coal and shale...........

Coal

Shale.

Coal.

Parting.

Coal.

Shale

Coal.

Shale and coal.............

Coal.

Shale and coal.

Coal, bright...............

Coal with many thin

shale bands.............

Gray shale.

Shale with standstone lenses and ironstone nodules.......

(Continued about 60 feet downstream on account of fault (?). Where recommenced there is only 34 feet to base of sandstone heading this section.)

Shale with a few coaly streaks. 2

Ironstone nodules.

Ft. in.

$\begin{array}{ll}2 & 9\end{array}$

25

4

$2-5$

$\begin{array}{ll}2 & 7\end{array}$

37

15

8

$4 \frac{1}{2}$

13

3

Shale with coaly lenses........

Bright coal...............

Shale.

Bright coal.............. 1

Parting.

Coal.

Parting.

Coal.

Shale.................. 1

Bright coal.............. 1

Shale.
36. West bank of Eska Creek about 1,250 feet below forks-Continued.

$\begin{array}{lll} & \text { Ft. } & \text { in. } \\ \text { Coal with shaly bands.... } & & 8\end{array}$

Shale.................... 10

Coal lens................ 0-2

Shale................... 14

Coal...................... $2-5$

Shale.................... $2 \quad 8$

Ironstone nodules.............. $\quad 4-6$

Shale..................... 5 5 9

Ironstone nodules............. $\quad 0-10$

Shale....................... 3

Coal..................... 2-6

Shale.................. 15

Coal with shaly bands.... 1

Shale................... 3

Coal with shaly bands.... 7

Shale................... 4

Coal with shaly bands.... $\quad 6$

Shale..................... 13

Ironstone nodules............. $\quad 6-18$

Shale.................... 2

Coal with shaly bands.... 12

Bright coal.............. 9

Parting with lenses of sandstone and shale.... $\quad 0-\frac{1}{2}$

Bright coal.............. 10

Shale with some coal.... $1-2$

Sandstone................. $3 \quad 9$

Strike N. $22^{\circ}$ E., dip $45^{\circ}$ NW.

37. West bank of Eska Creek about 1,100 feet below forks.

[Part of this section shown in Pl. XVII, $A,-$ p. 82.]

Sandstone. Ft. in.

Shale.................... 1

Coal................... $\quad 1 \frac{1}{2}$

Shale.................... 2

Coal.................. $14 \frac{1}{2}$

Parting.

Coal. .................. $8 \frac{1}{2}$

Shale...................

Dirty coal.............. $9 \frac{\mathrm{r}}{2}$

Coaly shale.............. 10

Coal................... 8

Coaly shale............... $4 \quad 9$

Shale................... $4 \quad 2$

Coal.................. 1

Coaly shale............. 10 
Sections of coal beds in lower Matanuska Valley-Continued.

37. West bank of Eska Creek about 1,100 feet below forks-Continued.

Shale.

Coal

Coal................. $2 \quad 2$

Shale................... 1

Coal.................. 12

Parting.

Coal. ................. 1

Coaly shale............... $2 \quad 10$

Coal. ................... 4

Shale.................. 1

Coal.................. 9

Shale................... $\frac{1}{2}$

Coal.................. $2 \frac{1}{2}$

Shale.................. 1

Coal.................. 9

Shale.................. $\frac{1}{2}$

Coal................... 2

Shale................... 1

Coal.................. 17

Shale with thin bands of coal ................... 3

Shale.................... 39

Shale with thin bands of coal ....................

Coal. ................. 1

Shale.......................

Coal. ....................

Shale.....................

Coal................... 2

Shale with ironstone nodules

Coal.

Shale

Coal. .................... 1

Shale with coaly bands....

Coal. ....................

Shale

Coal.

Shale with few thin bands of coal...................

Coal...................

Shale with many bands of coal ..................

Shale, with ironstone....... 13

Shale with a few bands of coal ..................

Coal (not well exposed where measured)....... 2

shale................... 3
37. West bank of Eska Creek about 1,100 feet below forks-Continued.

Coal ............... ${ }^{\text {Ft. }} \quad$ in.

Shale.................. $3 \frac{1}{2}$

Coal................... 10

Shale.................. $2 \frac{1}{2}$

Coal. ................. 6

Shale with thin bands of coal................ $2 \frac{1}{2}$

$\begin{array}{llll}\text { Shale with some ironstone..... } 27 \quad 6 & 6\end{array}$

Sandstone, upper foot shaly.... 4

Shale with some ironstone nod-

ules and petrified sticks..... $19 \quad 6$

Ironstone................. 3

$\begin{array}{lll}\text { Shale with bands of coal ... } & 1 & 9\end{array}$

Coal.................. $7 \frac{1}{2}$

Parting.

Coal.................. 11

Shale.................. 3

Ironstone............. 4

Shale.................. 13

Ironstone.............. 3

Shale................... 1

Shale with bands of coal ... $\quad 10$

Shale................... 7

Coal................... 6

Shale.................. 110

Coal. .................. 5

Shale..................., 10

Coal. ................. ' 4-12

Shale with bands of coal ... 14

Shale with sandstone and ironstone nodules (cliff)........ 37

Coal (petrified log seen in this bed) $\ldots \ldots \ldots \ldots \ldots \ldots . \quad 10$

Coaly shale.............. 2

Ironstone............... 4-8

Shale...................... 8

Ironstone................. 8

Shale.................... 35

Ironstone nodules.............. 7

Shale with ironstone nodules... $34 \quad 4$

Shale with little stringers of coal.................

Shale................... 110

Shale with coaly streaks ... 10

Ironstone nodules.............. 5

Shale with ironstone nodules ...................... 3 
Sections of coal beds in lower Matanuska Valley-Continued.

37. West bank of Eska Creek about 1,100 feet below forks-Continued.

Ft. in.

Clay ironstone............... $2 \quad 10$

Gray fissile shale............ 4

Sandy shale, somewhat mas-

sive.................... 3

38. Eska Creek 1,550 feet above third forks, at Shale. elevation 1,650 feet.

Coaly shale Ft. in.

Coal. 6

Coaly shale. 2

Coal with many thin shale bands ............... 6

ishale.

Strike N. $66^{\circ}$ E., dip $65^{\circ} \mathrm{SE}$.

39. East bank of Moose Creek 13,000 feet above U. S. land monument No. 5 .

Carbonaceous shale with ironstone nodules.

Carbonaceous shale with seams of bony coal

Coal.

t. in. 1

Bone and shale. 7

Coal 1

Bone. 10

Coal.

Shale with coaly streaks........

Coal. 7

Shale. 1

Coal.

Shale.

Coal.

Bone.

Coal.

Nodular shale.

Strike N. $65^{\circ}$ E., dip $83^{\circ} \mathrm{SE}$.

40. East bank of Moose Creek about 100 yards below upper cabin.

Coal with hard ferruginousinclu- Ft. in. sions.................... 3

Shale..................... 2

Coal (bright) ${ }^{1} \ldots \ldots \ldots \ldots .4 \quad 4 \quad 6$

Shale................... 2

Coal (bright and hard) ${ }^{1} \ldots \quad 7$

Soft shaly coal............ 1

Soft shale with abundant ironore concretions.

Strike N. $77^{\circ}$ E., $\operatorname{dip} 43^{\circ} \mathrm{NW}$.
41. East bank of Moose Creek 700 feet above U. S. land monument No. 5.

Shale.

Ft. in.

Arkose

Shale.......................... 10

Bone................... 1

Parting.

Coal ${ }^{2} \ldots \ldots \ldots \ldots \ldots \ldots . . \quad 8 \frac{1}{2}$

Parting (slickensided).

Coal..................... 7

Coal, somewhat bony..... 4

Coal with shaly bands.... $\quad 14$

Black shale with few coaly streaks................... 5

Coal with shale streaks........

Black shale................. 2

Ironstone concretions......... 2

Black and gray shale......... 10

Coal, dirty............. 3

Shale...................... 3

Coal with lenses of ferruginous nodules 2 inches thick....... 116

Shale with some coal.......... 146

Shale with ironstone nodules.. 3

Impure coal............. 10

Shale with ironstone nodules.. 2

Coal with much shale..... 1

Shale and ironstone nodules... 4

Impure coal............. 1

Shale with nodules and a few thin bands of coal......... 10

Coal with lenses of ferruginous nodules, 2 inches thick................ 3

Strike N. $78^{\circ} \mathrm{E} ., \operatorname{dip} 71^{\circ} \mathrm{NW}$.

42. One-elghth of a mile below upper cabin, Moose Creek.

Shale and sandstone roof. Ft. in.

Dirty coal............. 7

Shale.................... 3

Sandstone nodules........... 1

Bone and coal............ 13

Bone................. 1

Coal................... 3

Bone and shale............. 3

Coal................... 13

Bone.................. 1

Coal.................. 5

Shale.................... 1

1 Included in sample 20 , p. 91.

2 Major cleat N. $65^{\circ}$ E., dip $48^{\circ} \mathrm{SE}$; minor cleat N. $25^{\circ}$ W., dip $74^{\circ} \mathrm{NE}$. 
Sections of coal beds in lower Matanuska Valley-Continued.

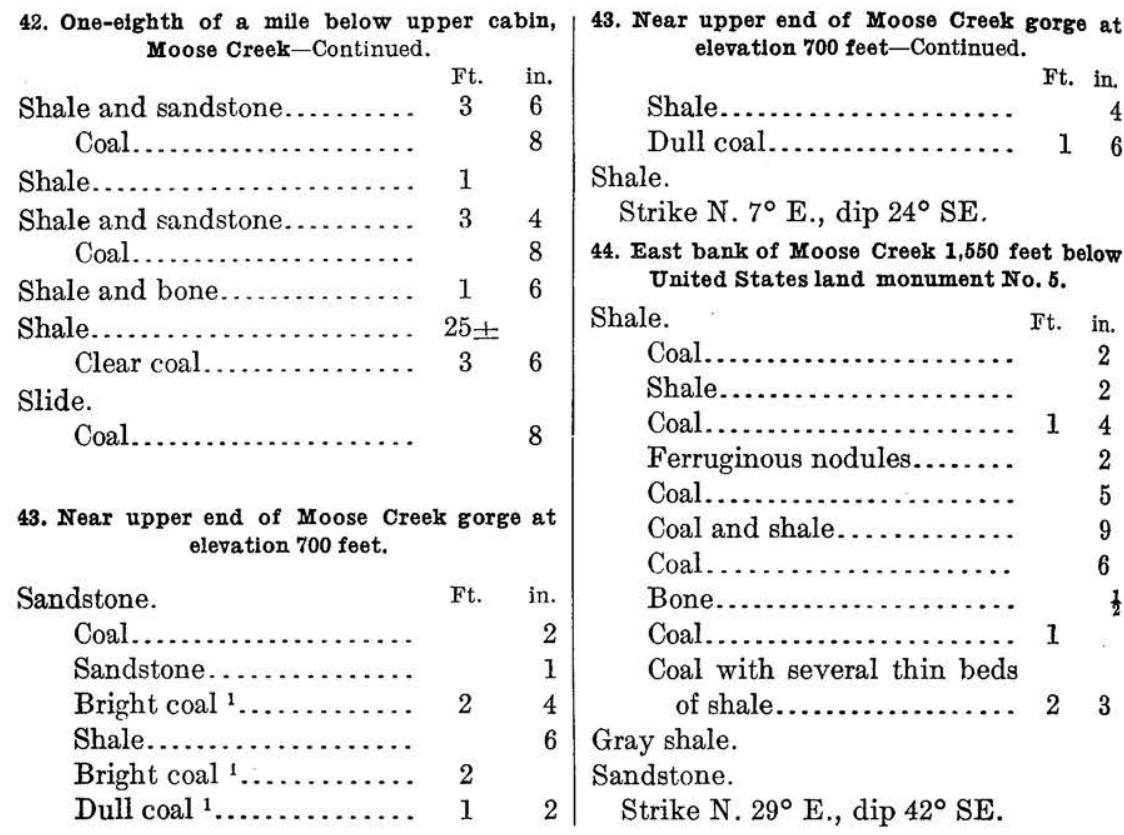

CHARACTER OF THE COAL.

PHYSICAL PROPERTIES.

The coal of the Matanuska Valley is of three kinds-anthracite, high-grade bituminous, and low-grade bituminous. Of these only the last two have been found within the area mapped in detail in the investigations here described. The anthracite occurs farther east and has been described in earlier reports. ${ }^{2}$

The high-grade bituminous coal occurs on the south side of the Matanuska, east of and in the vicinity of Coal Creek, and on the north side of the river in the valleys of Chickaloon and Kings rivers. The low-grade bituminous coal is known in the valleys of Young, Eska, and Moose creeks.

The high-grade bituminous coal is fragile and soft, like most coal of this kind, and the beds show the effects of having been severely crushed and at many places are without any well-defined bedding planes or planes of fracture. The friability of the coal is such that it will probably not stand shipment without being badly crushed. This is not so great a detriment as might at first seem, because many of the beds contain so many impurities that the coal from them ought

\footnotetext{
1 Included in sample 19, p. 91.

2 Martin, G. C., A reconnaissance of the Matanuska coal fleld, Alaska: Bull. U. S. Geol. Survey No. 289, 1906, pp. 18-19, 26-30. Paige, Sidney, and Knopf, Adolph, Geologic reconnaissance in the Matanuska and Talkeetna basins, Alaska: Bull. U. S. Geol. Survey No. 327, 1907, pp. 52-56, 59-63.
} 
to be crushed and washed. It is, moreover, highly probable that much of this coal will be used in the manufacture of coke, a purpose for which lump coal is not desired. Coal which possesses coking properties, as much or all of this coal does, can be burned as slack about as well as in lumps, for the slack coal when thrown into the furnace will fuse and cake, thus preventing loss of coal through the grates.

The low-grade bituminous coal on Moose, Eska, and Young creeks is on the border line between bituminous coal and black lignite. It is harder than the higher-grade coal farther east. Many of these beds have not been crushed and a larger proportion of lump coal can probably be obtained from them in mining than from the coal beds described above. This coal possesses no coking properties and will probably be used under stationary or locomotive boilers. It is not so good for this purpose as the coal from the east end of the field, but, because the latter is well suited for the manufacture of coke and for use as smithing and naval coal, it will command a higher price and thus probably leave a lower-price market for the poorer coal farther west. The low-grade coal can probably be mined and shipped more cheaply than the high-grade coal. The two kinds of coal will, to a certain extent, be noncompetitive, each having its own special markets.

\section{CHEMICAL ANALYSES AND TESTS.}

The following table includes characteristic analyses of coals from various parts of the area. Sample 1-1910 was taken during the investigations here described. The other analyses have been published in Bulletins 289 and 327 and represent samples collected in 1905. All the samples except Nos. 2215 and 2227 were obtained from surface prospects or from outcrops and were consequently somewhat weathered. Samples 2215 and 2227 came from a tunnel at a distance of 43 to 58 feet from the mouth of the tunnel and probably under about 25 or 30 feet of cover. 
Proximate analyses of Matanuska coals.

\begin{tabular}{|c|c|c|c|c|c|c|c|c|c|c|c|c|c|}
\hline \multirow{3}{*}{$\begin{array}{l}\text { No. of } \\
\text { sam- } \\
\text { ple. }\end{array}$} & \multirow{3}{*}{ Locality. } & \multirow{3}{*}{$\begin{array}{l}\text { Laboratory } \\
\text { number. }\end{array}$} & \multirow{3}{*}{$\begin{array}{l}\text { Thick- } \\
\text { ness of } \\
\text { coal } \\
\text { seam, in } \\
\text { feet. }\end{array}$} & \multirow{3}{*}{$\begin{array}{l}\text { Mois- } \\
\text { ture in } \\
\text { air- } \\
\text { dried } \\
\text { sam- } \\
\text { ple. } a\end{array}$} & \multirow{3}{*}{$\begin{array}{l}\text { Total } \\
\text { mois- } \\
\text { ture. }\end{array}$} & \multirow{3}{*}{$\begin{array}{l}\text { Volatile } \\
\text { matter. }\end{array}$} & \multirow{3}{*}{$\begin{array}{c}\text { Fixed } \\
\text { carbon. }\end{array}$} & \multirow{3}{*}{ Ash. } & \multirow{3}{*}{$\begin{array}{l}\text { Sul- } \\
\text { phur. }\end{array}$} & \multirow{3}{*}{$\begin{array}{c}\text { Calo- } \\
\text { ries } b \\
\text { per } \\
\text { pound } \\
\text { of coal. }\end{array}$} & \multicolumn{3}{|c|}{ Recalculated. } \\
\hline & & & & & & & & & & & \multicolumn{2}{|c|}{ Fuel elements. } & \multirow{2}{*}{$\begin{array}{l}\text { Fuel } \\
\text { ratio. }\end{array}$} \\
\hline & & & & & & & & & & & $\begin{array}{l}\text { Volatile } \\
\text { matter. }\end{array}$ & $\begin{array}{l}\text { Fixed } \\
\text { carbon. }\end{array}$ & \\
\hline \multirow{5}{*}{$\begin{array}{l}1 \\
2 \\
3 \\
4 \\
5\end{array}$} & Chickalocn River, tunnel No. 2. & 2215 & 12.3 & \multirow{4}{*}{$\begin{array}{l}0.98 \\
(c) \\
(c) \\
1.46 \\
1.00\end{array}$} & \multirow{4}{*}{$\begin{array}{l}2.58 \\
.90 \\
1.06 \\
2.46 \\
2.90\end{array}$} & \multirow{4}{*}{$\begin{array}{l}19.14 \\
19 . \mathrm{C0} \\
12.76 \\
17.01 \\
17.47\end{array}$} & \multirow{4}{*}{$\begin{array}{l}67.46 \\
74.60 \\
78.96 \\
53.23 \\
56.15\end{array}$} & \multirow{4}{*}{$\begin{array}{r}10.82 \\
4.90 \\
6.28 \\
27.30 \\
23.48\end{array}$} & \multirow{4}{*}{$\begin{array}{l}0.57 \\
.60 \\
.90 \\
.84 \\
.46\end{array}$} & & \multirow{4}{*}{$\begin{array}{l}22.10 \\
20.81 \\
13.91 \\
24.22 \\
23.73\end{array}$} & \multirow{4}{*}{$\begin{array}{l}77.90 \\
79.19 \\
86.09 \\
75.78 \\
76.27\end{array}$} & \multirow{4}{*}{$\begin{array}{l}3.52 \\
3.81 \\
6.19 \\
3.13 \\
3.21\end{array}$} \\
\hline & Chickaloon River, tunnel No. 2 (selected). & 2227 & 5.2 & & & & & & & 8,260 & & & \\
\hline & Chickaloon River, tunnel No. 3. & 2216 & 7.0 & & & & & & & …...... & & & \\
\hline & Chickaloon River, tunnel No. 5 . & 2220 & 7.9 & & & & & & & (n......... & & & \\
\hline & Average of analyses $1-5$. & & .... & $\cdots$ & 1.98 & 17.20 & 66.08 & 14.56 & .67 & ......... & 20.95 & 79.05 & 3.77 \\
\hline \multirow{6}{*}{\begin{tabular}{r|}
6 \\
7 \\
8 \\
9 \\
10 \\
11
\end{tabular}} & Matanuska River, south side, 3 miles above Chickaloon Creek. & 2214 & \multirow{5}{*}{$\begin{array}{l}7.0 \\
7.0 \\
5.0 \\
5.0 \\
8.6 \\
8.6\end{array}$} & \multirow{5}{*}{$\begin{array}{l}2.76 \\
(c) \\
1.44 \\
(c) \\
2.64 \\
(c) \\
\end{array}$} & \multirow{5}{*}{$\begin{array}{l}4.36 \\
4.15 \\
2.24 \\
1.88 \\
6.74 \\
5.83\end{array}$} & \multirow{5}{*}{$\begin{array}{l}18.92 \\
20.63 \\
23.08 \\
22.51 \\
14.96 \\
18.24\end{array}$} & \multirow{5}{*}{$\begin{array}{l}61.19 \\
59.62 \\
70.21 \\
71.65 \\
65.83 \\
63.03\end{array}$} & 15.53 & \multirow{5}{*}{$\begin{array}{l}.37 \\
.34 \\
.50 \\
.44 \\
.44 \\
.47\end{array}$} & .. & 23.62 & 76.38 & 3.23 \\
\hline & 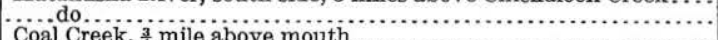 & 2217 & & & & & & 15.60 & & $\cdots$ & 25.71 & 74.29 & 2.89 \\
\hline & 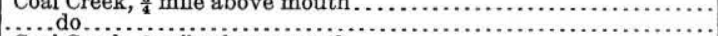 & & & & & & & $\begin{array}{l}4.47 \\
3.96\end{array}$ & & & 23.91 & 76.09 & $\begin{array}{l}.04 \\
3.18\end{array}$ \\
\hline & Coal Creek, $\frac{3}{5}$ ile above mouth............. & 2219 & & & & & & 12.47 & & 6,649 & 18.52 & & 4.40 \\
\hline & ......do. & & & & & & & 12.90 & & .......... & 22.44 & 77.56 & 3.46 \\
\hline & Average of analyses $6-11 .$. & & & & 4.20 & 19.72 & 65.26 & 10.82 & .42 & ........ & 23.14 & 76.86 & 3.32 \\
\hline 12 & Kings River, west bank, upper bridge. & 2218 & 9.9 & 1.13 & 2.93 & 21.85 & 63.09 & 12.13 & .59 & 7,419 & 25.72 & 74.28 & 2.89 \\
\hline 13 & $\dddot{\text { zings }}$ do & ...... & 9.9 & (c) & 1.22 & 24.15 & 62.65 & 11.98 & .52 & -........ & 27.82 & 72.18 & 2.59 \\
\hline $\begin{array}{l}14 \\
15\end{array}$ & Kings & ..... & 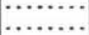 & $\begin{array}{l}(c) \\
(c)\end{array}$ & $\begin{array}{r}1.15 \\
.50\end{array}$ & $\begin{array}{l}23.09 \\
22.00\end{array}$ & $\begin{array}{l}69.34 \\
70.50\end{array}$ & $\begin{array}{l}6.42 \\
7.00\end{array}$ & .89 & …...... & $\begin{array}{l}24.98 \\
23.78\end{array}$ & $\begin{array}{l}75.02 \\
76.22\end{array}$ & $\begin{array}{l}3.00 \\
3.20\end{array}$ \\
\hline & Average of analyses $12-15$. & & & & 1.45 & 22.77 & 66.40 & 9.38 & .67 & & 25.57 & 74.43 & 2.91 \\
\hline 16 & Young Creek, 3 miles above trail. & 2223 & 1.0 & (c) & 2.50 & 28.32 & 58.82 & 10.36 & .58 & * & 32.50 & 67.50 & 2.08 \\
\hline & Average of analyses 1-16. & & ......... & ......... & 2.71 & 20.23 & 65.39 & 11.60 & .57 & $\ldots \ldots$ & 23.65 & 76.35 & 3.23 \\
\hline 1-1910 & Red Mountain (Young Creek).. & $11382 \mathrm{~F}$ & $\overline{12.2}$ & 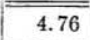 & 10.57 & 33.80 & 50.57 & 5.06 & .23 & 6,236 & 40.07 & 59.93 & $\overline{1.50}$ \\
\hline 17 & Eska Creek, 3 miles above trail.. & $\begin{array}{l}2226 \\
2224\end{array}$ & 2.6 & (c) & $\begin{array}{l}5.56 \\
6.60\end{array}$ & $\begin{array}{l}36.52 \\
34.30\end{array}$ & $\begin{array}{l}51.32 \\
48.23\end{array}$ & $\begin{array}{r}6.60 \\
10.87\end{array}$ & .42 & 6.299 & $\begin{array}{l}41.58 \\
41.56\end{array}$ & $\begin{array}{l}58.42 \\
58.44\end{array}$ & 1.41 \\
\hline & Average of analyses $17-18 .$. & & & $\ldots \ldots$ & 6.08 & 35.41 & 49.78 & 8.23 & 42 & & 41.57 & 58.43 & 1.41 \\
\hline
\end{tabular}




\begin{tabular}{|c|c|c|c|c|c|c|c|c|c|c|c|c|}
\hline 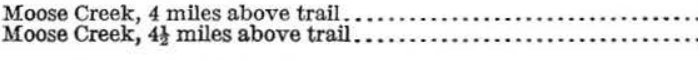 & $\begin{array}{l}2225 \\
2221\end{array}$ & $\begin{array}{r}6.0 \\
11.7 \\
\end{array}$ & $\begin{array}{l}(c) \\
5.45\end{array}$ & $\begin{array}{r}4.03 \\
10.05 \\
\end{array}$ & $\begin{array}{l}34.84 \\
36.05 \\
\end{array}$ & $\begin{array}{l}49.31 \\
48.90 \\
\end{array}$ & $\begin{array}{r}11.82 \\
5.00 \\
\end{array}$ & $\begin{array}{l}.38 \\
.25 \\
\end{array}$ & $|\cdots \cdots \cdots \cdot|$ & $\begin{array}{l}41.40 \\
42.44 \\
\end{array}$ & $\begin{array}{l}58.60 \\
57.56 \\
\end{array}$ & $\begin{array}{l}1.42 \\
1.36 \\
\end{array}$ \\
\hline $\begin{array}{l}\text { Average of analyses } 19-20 \ldots \\
\text { Average of analyses } 17-20 \ldots\end{array}$ & & & & $\begin{array}{l}7.04 \\
6.56\end{array}$ & $\begin{array}{l}35.45 \\
35.43\end{array}$ & $\begin{array}{l}49.10 \\
49.44\end{array}$ & $\begin{array}{l}8.41 \\
8.32\end{array}$ & .32 & & $\begin{array}{l}41.92 \\
41.74\end{array}$ & $\begin{array}{l}58.08 \\
58.26\end{array}$ & $\begin{array}{l}1.39 \\
1.40\end{array}$ \\
\hline
\end{tabular}

$a$ Determined by drying in the open air until weight becomes constant.

$b$ A calorie is the amount of heat necessary to raise the temperature of 1 pound of water $1^{\circ} \mathrm{C}$. It is equal to 1.8 British thermal units. c Not determined.

1-2, 4-6, 8, 10, 12, 16-20. Sampled by G. C. Martin. Analyses by F. M. Stanton, U. S. Geological Survey coal-testing plant, St. Louis, Mo.

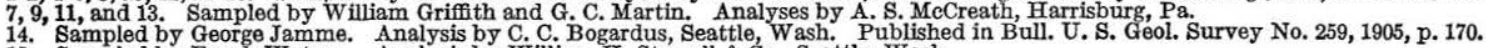
15. Sampled by Frank Watson. Analysis by William H. Stowell \& Co., Seattle, Wash. 
Analyses $a$ and tests of Matanuska coals.

\begin{tabular}{|c|c|c|c|c|c|c|c|c|c|c|c|c|c|}
\hline \multirow[b]{2}{*}{$\begin{array}{c}\text { Sam- } \\
\text { ple } \\
\text { No. }\end{array}$} & \multirow{2}{*}{$\begin{array}{l}\text { Thick- } \\
\text { ness } \\
\text { of coal } \\
\text { in feet. }\end{array}$} & \multicolumn{5}{|c|}{ Proximate analysis. } & \multicolumn{5}{|c|}{ Ultimate analysis. } & \multicolumn{2}{|c|}{$\begin{array}{c}\text { Calorific } \\
\text { value. }\end{array}$} \\
\hline & & $\begin{array}{l}\text { Loss } \\
\text { on air- } \\
\text { dry- } \\
\text { ing. }\end{array}$ & $\begin{array}{l}\text { Total } \\
\text { mois- } \\
\text { ture. }\end{array}$ & $\begin{array}{l}\text { Vola- } \\
\text { tile } \\
\text { com- } \\
\text { busti- } \\
\text { ble. }\end{array}$ & $\begin{array}{c}\text { Fixed } \\
\text { car- } \\
\text { bon. }\end{array}$ & Ash. & $\begin{array}{l}\text { Sul- } \\
\text { phur. }\end{array}$ & $\begin{array}{l}\text { Hy- } \\
\text { dro- } \\
\text { gen. }\end{array}$ & $\begin{array}{l}\text { Car- } \\
\text { bon. }\end{array}$ & $\begin{array}{l}\mathrm{Ni}- \\
\text { tro- } \\
\text { gen. }\end{array}$ & $\begin{array}{l}\text { Oxy- } \\
\text { gen. }\end{array}$ & $\begin{array}{l}\text { Calo- } \\
\text { ries. }\end{array}$ & $\begin{array}{c}\text { British } \\
\text { thermal } \\
\text { units. }\end{array}$ \\
\hline $\begin{array}{r}1 \\
2 \\
8 \\
12 \\
1-1910 \\
17 \\
18 \\
19 \\
20\end{array}$ & $\begin{array}{r}12.3 \\
5.2 \\
5.0 \\
9.9 \\
12.2 \\
2.6 \\
3.3 \\
6.0 \\
11.7\end{array}$ & $\begin{array}{r}1.60 \\
\cdots .80 \\
1.80 \\
6.10 \\
\cdots \cdots \\
\hdashline \ldots \ldots \\
\hdashline 4.60\end{array}$ & $\begin{array}{r}2.55 \\
.99 \\
1.97 \\
2.68 \\
10.57 \\
4.74 \\
5.00 \\
4.75 \\
9.49\end{array}$ & $\begin{array}{l}16.66 \\
19.03 \\
18.58 \\
20.69 \\
33.80 \\
34.79 \\
33.90 \\
32.64 \\
33.63\end{array}$ & $\begin{array}{l}69.72 \\
75.19 \\
75.19 \\
64.72 \\
50.57 \\
54.06 \\
50.65 \\
50.63 \\
51.71\end{array}$ & $\begin{array}{r}11.07 \\
4.79 \\
4.26 \\
11.91 \\
5.06 \\
6.41 \\
10.45 \\
11.98 \\
5.17\end{array}$ & $\begin{array}{r}0.57 \\
.60 \\
.50 \\
.59 \\
.23 \\
.42 \\
.41 \\
.38 \\
.25\end{array}$ & $\begin{array}{l}4.19 \\
4.71 \\
4.80 \\
4.68 \\
5.41 \\
5.54 \\
4.77 \\
4.76 \\
5.52\end{array}$ & $\begin{array}{l}76.58 \\
83.90 \\
82.77 \\
74.38 \\
65.16 \\
71.06 \\
63.59 \\
64.09 \\
65.85\end{array}$ & $\begin{array}{l}1.37 \\
1.48 \\
1.79 \\
.87 \\
1.13 \\
1.60 \\
1.38 \\
1.09 \\
1.20\end{array}$ & $\begin{array}{r}6.22 \\
4.52 \\
5.88 \\
7.57 \\
23.01 \\
14.97 \\
19.40 \\
17.70 \\
22.01\end{array}$ & $\begin{array}{l}7,545 \\
8,205 \\
8,146 \\
7,422 \\
6,236 \\
6,985 \\
6,338 \\
6,428 \\
6,445\end{array}$ & $\begin{array}{l}13,581 \\
14,769 \\
14,663 \\
13,360 \\
11,225 \\
12,573 \\
11,408 \\
11,570 \\
11,601\end{array}$ \\
\hline
\end{tabular}

$a$ These analyses were made by F. M. Stanton on the same samples as those with corresponding num. bers in the preceding table. The differences in proximate analyses are due to the fact that the samples dried somewhat in the months which elapsed between analyses, and that somewhat different methods of analysis were used. (See Bull. U. S. Geol. Survey No. 290, 1906, pp. 29-30.)

\section{COKING QUALITIES.}

A rough test of the coking qualities of the coal from tunnel No. 2 on Chickaloon Creek (see p. 80) was made during the summer of 1905 by coking a large pile of coal under a covering of stones and dirt. The resulting coke was hard and firm and had a good ring and a good texture. The test indicated that by proper treatment a coke of satisfactory grade can be produced.

No further tests have been made by members of the Geological Survey. The analyses indicate, however, that the high-grade bituminous coal on Chickaloon and Kings rivers and on Coal Creek is probably, at least in part, coking coal, and that the coal in the west end of the district, on Moose, Eska, and Young creeks, is low-grade bituminous and is probably all noncoking coal.

\section{MINING CONDITIONS.}

MINE SITES.

Mine sites should be selected only after a careful study of local conditions accompanied by drilling. The selection of a site should be governed by the accessibility to the railroad and by the structure of the rocks. The latter should be determined in detail for each property by careful drilling or otherwise, in order that the mine may be opened at such a point that the underground haulage of the coal and the disposal of the mine waters may be accomplished at a minimum expense.

Although many of the coal beds outcrop at the surface, the outcrops dip for the most part at steep angles. (See Pl. XIX.) Few if any localities have been found at which it would be possible to open an extensive mine on the outcrop of the coal bed. The amount of coal above the general drainage level is not great and it will be necessary from the very beginning of mining to sink shafts or slopes to consider- 


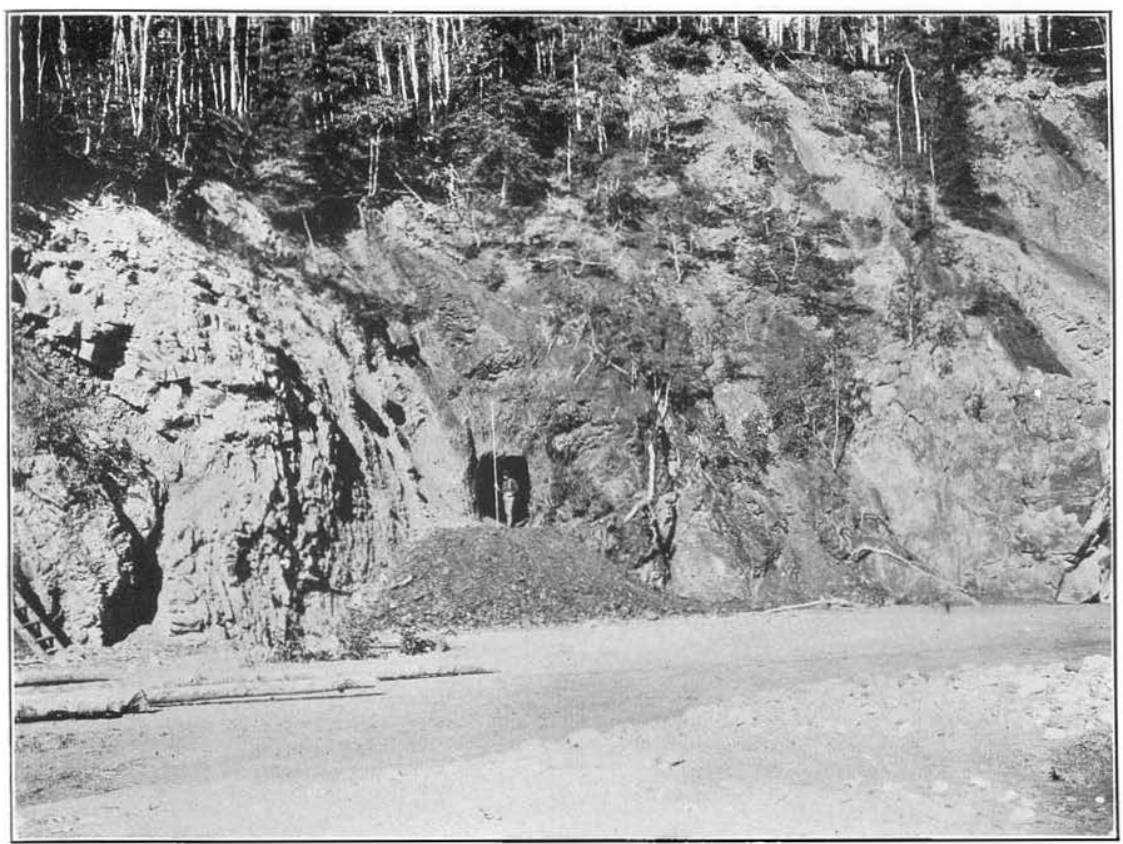

A. COAL BED IN WEST BANK OF CHICKALOON RIVER AT BEND ABOVE COAL CAMP.

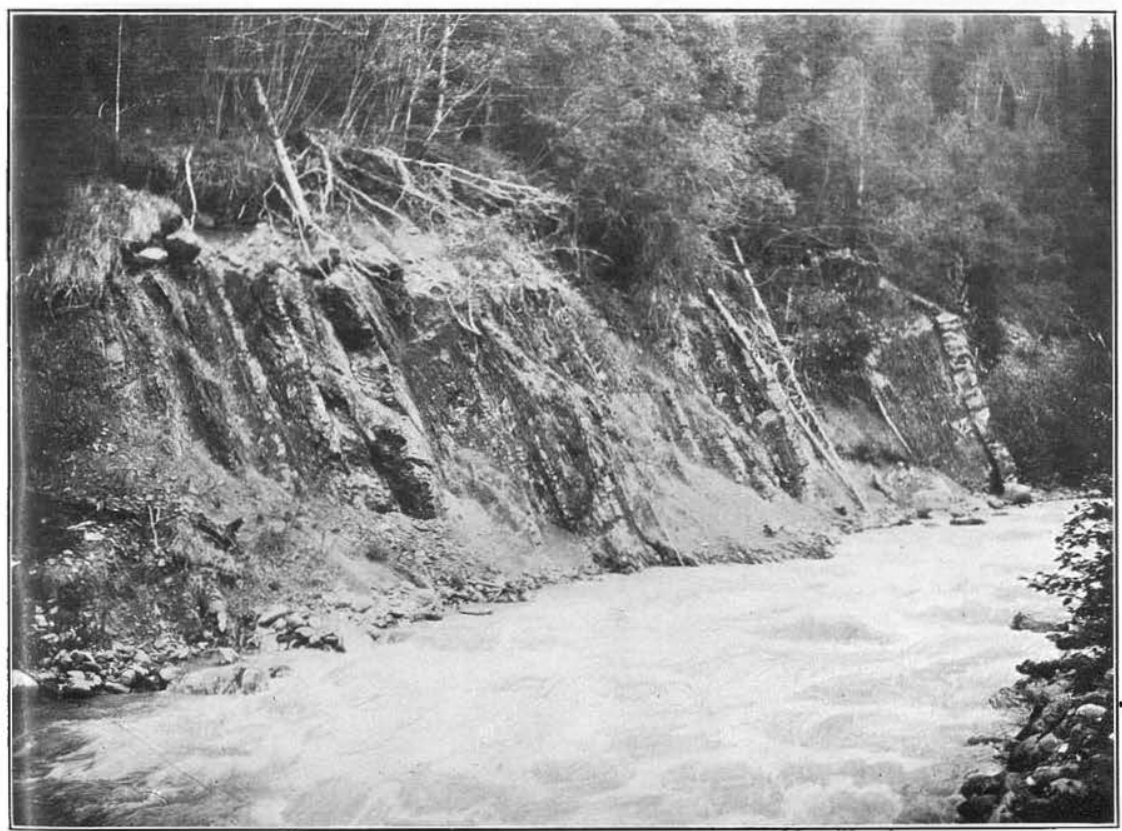

B. COAL BED IN EAST BANK OF COAL CREEK SEVEN-EIGHTHS OF A MILE ABOVE ITS MOUTH. 

able depths. When any large mines are opened it will probably be found desirable to sink shafts to the coal beds at considerable distances from their outcrops.

LOCAL SUPPLIES.

The local region will furnish none of the supplies needed in coal mining except timber. Everything else will have to be shipped from outside of Alaska. The development of this field on a large scale will consequently probably involve the building up of other industries, such as establishments for the manufacture of mine cars and other machinery and mine supplies.

\section{UNDERGROUND WATER AND GAS.}

In any large mines which are opened in this region it will be necessary from almost the beginning of mining to pump or hoist mine water. It is not believed that it will be possible to open any large mines having natural drainage. The amount of underground water which will be encountered will probably not be great, unless the mines are opened on the outcrop. Precipitation in this region is so slight that large amounts of water can get into the mines only from the streams. If ordinary precautions are taken to prevent streams from breaking into the mine openings the mines ought to be fairly dry.

The heavy cover of gravel which exists at the lower altitudes throughout most of the Matanuska Valley will cause certain dangers in mining. Unless the depth of the gravel at different points and the shape of the underlying rock floor are determined by drilling there will be danger of the mine workings breaking through the surface of the rock into the gravels. The gravels probably carry large amounts of water in some places and serious accidents might thus result.

Gas will probably be a serious problem in local mining from the very start. The experience of the few small tunnels which have been driven indicates that these coal beds will yield large amounts of dangerous gases. Some provision ought to be made in advance of mining for the enforcement of suitable regulations insuring the protection of the miners and the mines against gas explosions.

\section{EFFECT OF INTRUSIVE ROCKS.}

Intrusive rocks are known to be present in abundance and in large masses throughout the greater part of the area of coal-bearing rocks, except in the valleys of Moose and Eska creeks, where they are small and are much less numerous than farther east. The areal distribution of the larger of these intrusive masses is indicated on the map (Pl. V, in pocket). Small dikes and sills, not represented on the map, are also present throughout practically all the coal areas. Where the intrusive rocks cut the coal beds the coal is rendered worthless for a distance of a few inches from the contact. The small dikes and sills, on account of the short distances to which their effect extends, do 
not affect the coal seriously, except that the sills show a habit of seeking coal beds for their planes of intrusion. It is clear that if a sill is intruded into a coal bed for a long distance a large amount of worthless coal will result, but if it is intruded between rock strata, even if only a few feet away from a coal bed, or if it cuts across the coal bed in the form of a dike, its effect on the coal will be slight.

The larger intrusive masses are of much more serious importance than the small dikes and sills, first, because their size is of itself sufficient to reduce the coal areas considerably, and second, because each of them is likely to have sent off many apophyses in the form of sills in or along the surfaces of coal beds. The dimensions of these masses are, moreover, probably greater under ground than at the surface. There may also be many intrusive masses which do not outcrop but which are near enough to the surface to be encountered in mining.

In conclusion, it must be stated that the presence of intrusive rocks in the coal field introduces factors that make an undetermined percentage of the coal areas of very doubtful value. The size and distribution of these intrusive masses beneath the surface, as well as at the surface in the areas of scanty outcrops, can not be determined without underground exploration. The effect of the smaller intrusive masses on the coal depends on the extent to which these masses have been intruded into or along the surfaces of coal beds. Where the intrusive mass is in contact with the coal the coal is worthless, but where it is a few feet away the quality of the coal is probably unimpaired, or may even be improved.

EFFECT OF FOLDING AND FAULTING.

The steep dips and complex structure of much of the coal areas introduce serious problems in coal mining and call for careful investigation of the structural conditions of each individual tract before the development of mines is attempted. It is believed that areas will be found in which the difficulties of mining, due to structure, will not be serious.

Both Castle Mountain and Wishbone Hill are of fairly simple structure, so that, if the coal beds persist beneath the conglomerate and if the coal-bearing rocks were not folded before the conglomerate was laid down, mining should not be difficult, at least so far as structural conditions are concerned.

It may perhaps be assumed to be probable that the structures of the entire valley are of the same general type as those known in the areas of the conglomerate. If this is the case, there are probably large areas in which the structure will permit the mining of the coal. This condition is not, however, positively known, and the character of the structure must be regarded as a problem to be solved by underground exploration before the feasibility of mining at a profit the coal of any particular tract can be demonstrated. 
METALS.

Within the area covered by the detailed investigations on which this report is based there are no known metalliferous deposits. Indications of metalliferous mineralization were seen only at localities along the great fault which marks the contact of older rocks with the Upper Cretaceous and Tertiary sediments of the Matanuska basin. At one place a thin stain of copper carbonates was seen on crushed and altered granite in the fault zone. At another place crushed, epidotized, and quartz-veined rock carries iron pyrites. Copper stains were observed at the contact of the limestone and the underlying volcanic rocks on the ridge north of Castle Mountain. Colors of gold are reported to have been found in the gravels of Granite Creek.

In the environs of the region considered there are prospects to the east on Caribou Creek and to the north on Kings River and Moose Creek, and there are mines and prospects to the west in the Willow Creek region.

A little placer gold is reported to have been produced on Caribou Creek. No details are known about the occurrence of the gold.

Claims located on copper prospects in the basin of Kings River about 12 miles above the mouth have not been visited by members of the Survey, and no information about them is at hand.

It is reported that sulphide mineralization has been found in the granite area of the upper part of Moose Creek.

Willow Creek produced some placer gold in 1898, and gold placer mines on Grubstake Gulch began producing in 1900. The Grubstake Gulch deposits are in the area of albite-chlorite schists discussed on page 15. (See also Pl. III in pocket.) These deposits have been described in earlier publications of the Survey. ${ }^{1}$ In the Willow Creek region gold-quartz prospects are being developed. These are in quartz veins which traverse quartz diorite. Several veins of promising character have been located in the divides between the headwaters of Willow Creek and tributaries of Little Susitna River. They have been described by $\mathrm{Katz}^{2}$ in a recent publication of the Survey.

The crystalline rocks in which the above-noted prospects and mines occur occupy most of the mountain province north of Matanuska River and west of Chickaloon River.

Nothing has been learned concerning the copper prospects noted by Paige and Knopf ${ }^{3}$ in the Knik River and Kashwitna River regions.

1 Paige, Sidney, and Knopt, Adolph, Geologic reconnaissance in the Matanuska and Talkeetna basins, Alaska: Bull. U. S. Geol. Survey No. 327, 1907, pp. 65-67. Katz, F. J., A reconnaissance of the Willow Creek gold region: Bull. U. S. Geol. Survey No. 480, 1911, pp. 139-152.

$2 \mathrm{Katz}, \mathrm{F}$ J. op. cit.

3 Paige, Sidney and Knopf, Adolph op. cit., pp. 67-68. 



\section{INDEX.}

A. Page.

Agglomerate, distribution, character, and age of....................... 29-32

Alaska, central portion of, map showing..... 10

Alluvium, character and distribution of..... 71-72

Arkose, character and distribution of ........ 39-42

in Sheep Valley, plates showing..........

near Moose Creek, plate showing..........

B.

Basaltic lavas, character and distribution of.. 54-55 Boulder Creek, gabbro in shale near, figure showing........................ 67

Brooks, A. H., preface by .

C.

Castle Mountain, Eska conglomerate of, plates

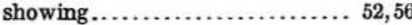

relations of gabbro and Tertiary sediments at, figure showing.........

section of rocks in and figure showing...

Chapin, Theodore, work of .................

Chickaloon, coal beds at.

meteorological observations at.......... 12

relation of diabase to Chickaloon formation at, figure showing............

relation of gabbro to Chickaloon formation near, figure showing........

tunnels at, figure showing..............

Chickaloon coal camp, sections of Chickaloon formation at................. 43-46

Chickaloon formation, character and distribution of ................... 42-52

diabase dikes in, plate showing.......... 64

folded beds of, figure showing............ 60

fossils of ......................... 49-52

sections of.................. 43-46, 47-48, 49

sills and dikes in, figures showing....... 65,66

Chickaloon River, coal bed near, plate show-

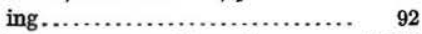

coal beds on or near, sections of......... 77,78

porphyry sills and dikes near, plate showing ........................... 56

relation of diabase sills to Chickaloon formation near, figures showing....66, 67 section of Chickaloon formation near.... 43-44

Coal, areal distribution of................. $75-76$ areal distribution of, map showing.. In pocket beds of, descriptions of................. $76-88$ plates showing.................... 82,92 character of.......................... $88-89$ chemical analyses of.................. 89-90 coking qualities of ..................... 92 mining conditions of.................. 92-94 stratigraphic occurrence of...............

$$
9949^{\circ}-\text { Bull. } 500-12-7
$$

Page.

Coal Creek, coal bed near, plate showing..... $\quad 92$ coal beds on, sections of................ $77-78$ Climate, features of..................... 11-12 Commerce, development of............... 14 Conglomerate, Tertiary, character and distribution of ..................... 39-42

Copper, occurrence of .................... 95 Cretaceous rocks, character and distribution of............................ 22-23

D.

Diabase, character and distribution of...... 63-67 dikes and sills of, figures showing .......65,66 dikes of, plate showing................ 64

Diorite porphyries, character and distribution of...................... 56-61 relation of, to sediments, figures showing. 59,60

$\mathrm{E}$.

Eska conglomerate, character and distribution of........................ 52-54 plates showing..................... 52,56

Eska Creek, coal beds of, plate showing..... 82 coal beds on, sections of............. 82-87 Eska conglomerate near, plate showing.. $\quad 52$ section of Chickaloon formation on....... 48

F.

Faulting, effect of...................... 94

Faults, plate showing..................... 72

Fauna, Lower Jurassic, report on... 20, 22, 30,31-32 Tertiary, report on.................... 52 Upper Cretaceous, report on........... 36-39 Flora, Tertiary, report on............. 42,49-52 Folding, effect of...................... 94

G.

Gabbro, character and distribution of........ 63-67 in shale near Boulder Creek, figure showing......................... 67 sills and dikes of, figures showing.......66, 67 Gas, in mines, effect of .................. 93 Geography, account of.................. 10-11

Geology, detailed discussion of............... 26-72 general features of ................... 14-26 structural features of .................. $72-75$ Gneissic rocks, distribution, age, and character of...................... 26-29

Gold, occurrence of....................... 95 Granite, relations of, to arkose, in Sheep Valley, plates showing............. 28

Granite Creek, Upper Cretaceous rocks of, section of ...................... 34-35

Granitic rocks, character and distribution of...................... 19,26-29 
Gravel beds, plate showing................ $\quad 70$ Graywackes, of Knik River, character of..... 16-17 H.

Hollick, Arthur, on Tertiary fossils $42,49-51$

\section{I.}

Intrusive rocks, effect of. 93-94 Investigations, account of.

\section{J.}

Jurassic rocks, character and distribution of. 17-22

K.

Katz, F. J., work of.

Kings Creek, coal bed on.................. 82

Kings River, coal beds on or near......... 81-82 section of Chickaloon formation near..... 47 stratified gravels near, plate showing .... $\quad 70$ terraces on, figure showing ............. $\quad 70$

Knik River, graywackes and slates of........ 16-17 Knowlton, F. H., on Tertiary fossils ...... 42,51-52

\section{L.}

Limestone, Lower Cretaceous, distribution, age, and character of.......... 32-33

Lower Cretaceous rocks, character and distribution of ............. 22-23,32-33

Lower Jurassic rocks, character and distribution of. $17-19,29-31$

\section{M.}

Martin, G. C., work of.

Matanuska River, coal bed on porphyry sill near, plate showing........ section of Chickaloon formation on.......

Matanuska Valley, location of.

location of, map showing............... north wall of, plate showing............. topographic and geologic maps of.... In pocket stratigraphic sequence in............... 15

Metals, occurrence of ..................... 95

Mica schists, character and distribution of... 15

Middle Jurassic rocks, character and distribution of ...................... 20-22

Mineral resources, detailed account of....... 75-95

Mine sites, conditions affecting choice of .... 92-93

Moose Creek, coal beds on................ 87-88 gravel beds near, plate showing........ 70 section of Chickaloon formation near..... 49 terraces on, figure showing.............. 70

Morainic deposits, character and distribution of............................. $68-69$

N.

Navigation, conditions affecting

P.

Porphyry sills, plate showing.

Precipitation, data on
Q.

Page.

Quaternary deposits, character and distribution of. 25-23, $67-72$

R.

Railroads, surveys for ................... 13

Red Mountain, coal bed on.............. 82

Routes, data on ........................ 13

S.

Shale, Tertiary, character, and distribution of. $39-42$ Sheep Valley, granite and arkose in, plates showing ..................... 28

Slates, of Knik River, character of........ 16-17

Stanton, T. W., on Jurassic fossils.. 20, 22, 30,31-32 on Tertiary fossils.................. 52

on Upper Cretaceous fossils............. 36-39

Structure, general features of ............. 72-75

Structure sections, plates showing........... 72

Supplies, availability of.................. 93

Surveys, account of.................... 9-10

T.

Talkeetna Mountains, plate showing....... 10

Temperature, data on................... 12

Terrace gravels, character and distribution of. $69-71$ on Moose Creek and Kings River, diagram showing............... 70

Tertiary fossils, identifications of .......... 42

Tertiary intrusive rocks, character and distribution of .................... 54-67

Tertiary lavas, Eska conglomerate overlying, plate showing................ 56

Tertiary rocks, character and distribution of ...................... 24-25,39-67

Trachytic rocks, character and distribution of 62-63 Trails, character of ...................... $1:$ Tuff, Jurassic, distribution, age, and character of........................ 29-32

Tuffs, Tertiary, character and distribution of. 54-55

U.

Upper Cretaceous rocks, character and distribution of............... 23, 34-39

Upper Jurassic rocks, character and distribution of.

V.

Vegetation, character of.................

Volcanic breccia, distribution, character, and age of. 29-32

W.

Water, underground, effect of .............

Wishbone Hill, Eska conglomerate at, plate showing.

Y.

Young Creek, coal beds on.................. 82 fault near, plate showing............... 72 porphyry sill near, plate showing........ 56 relation of diorite porphyries to sediments on, sections showing............ 59,60 




$$
\text { I 19. 3:500 }
$$

4 MAPS 


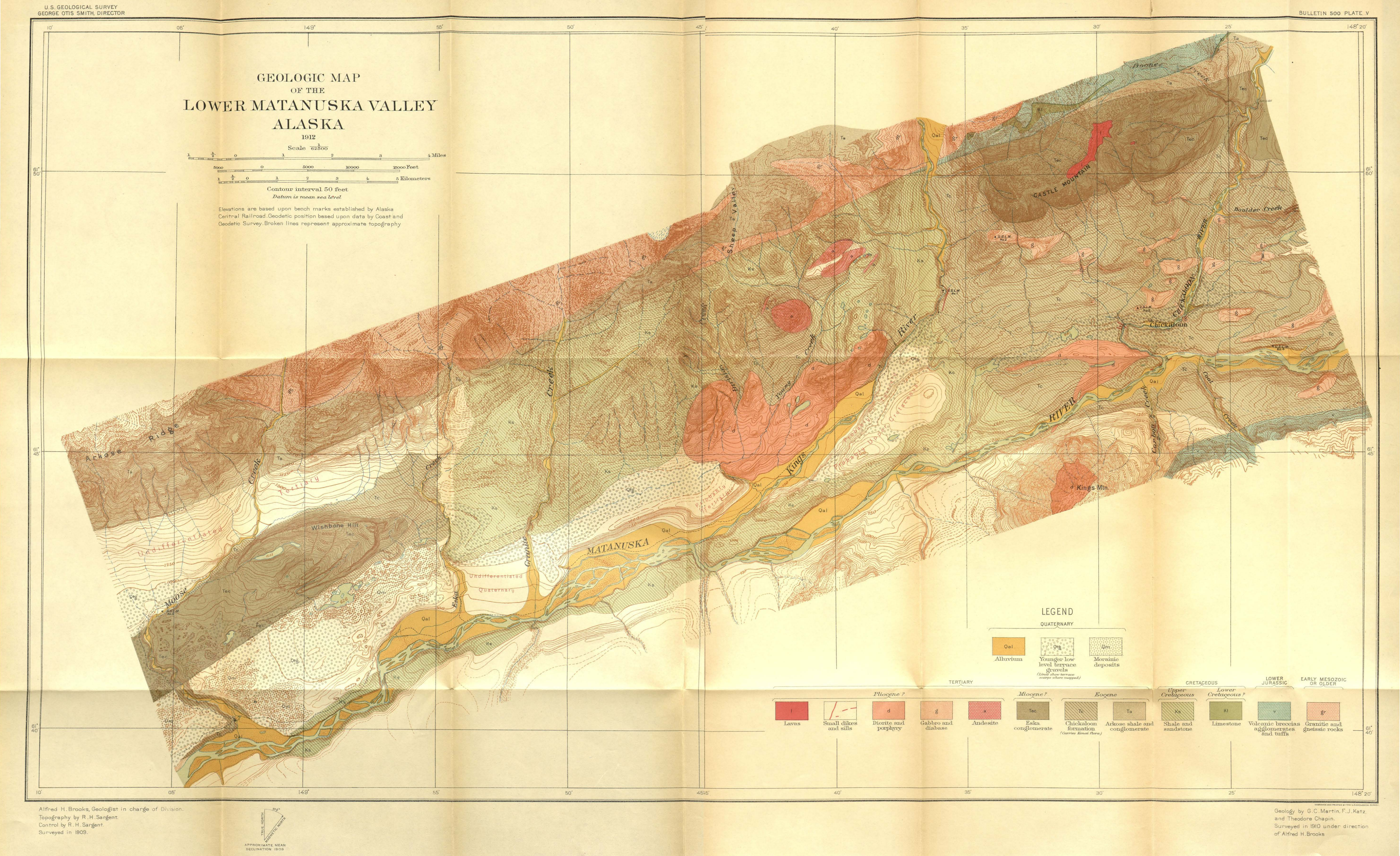




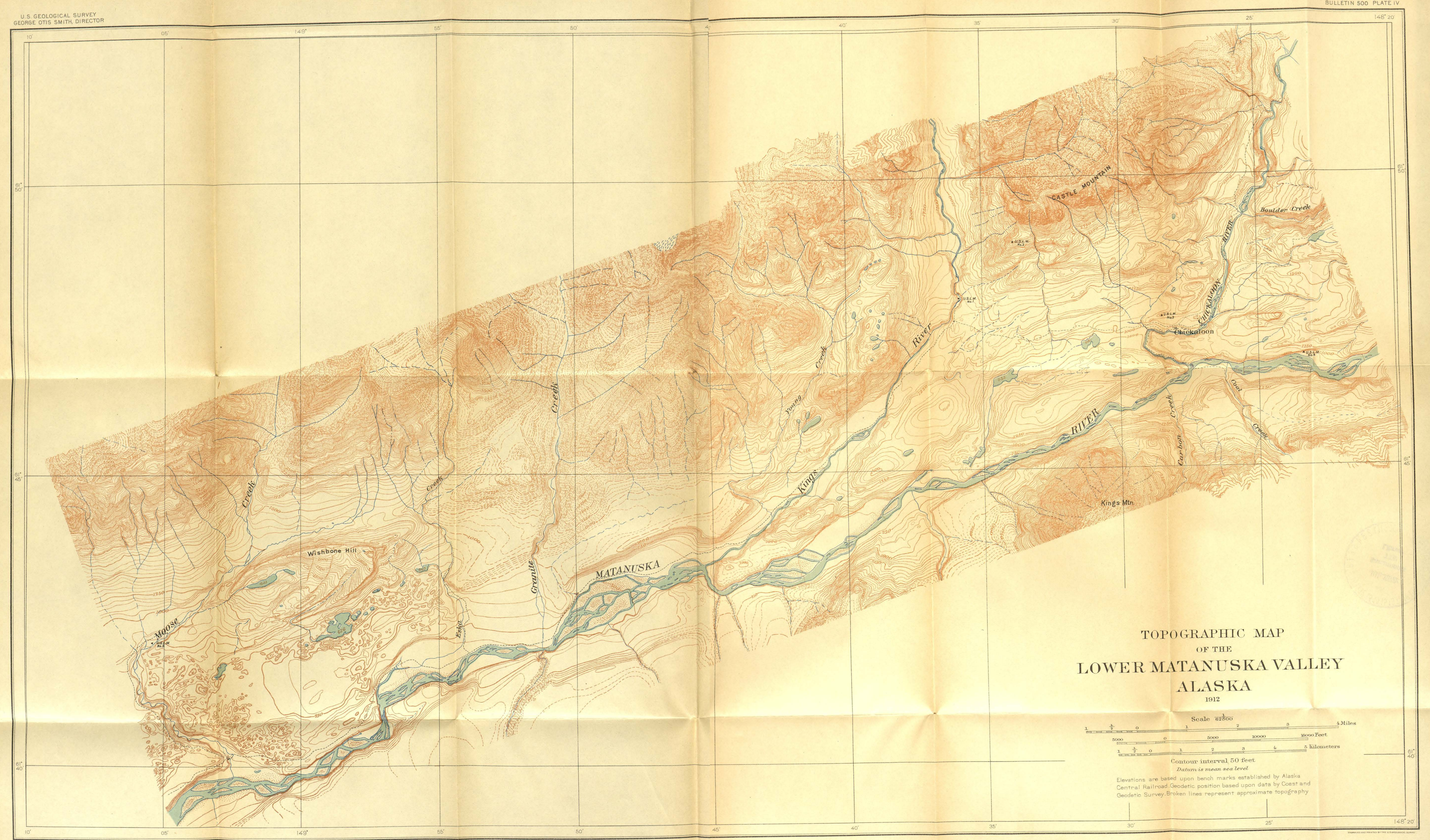




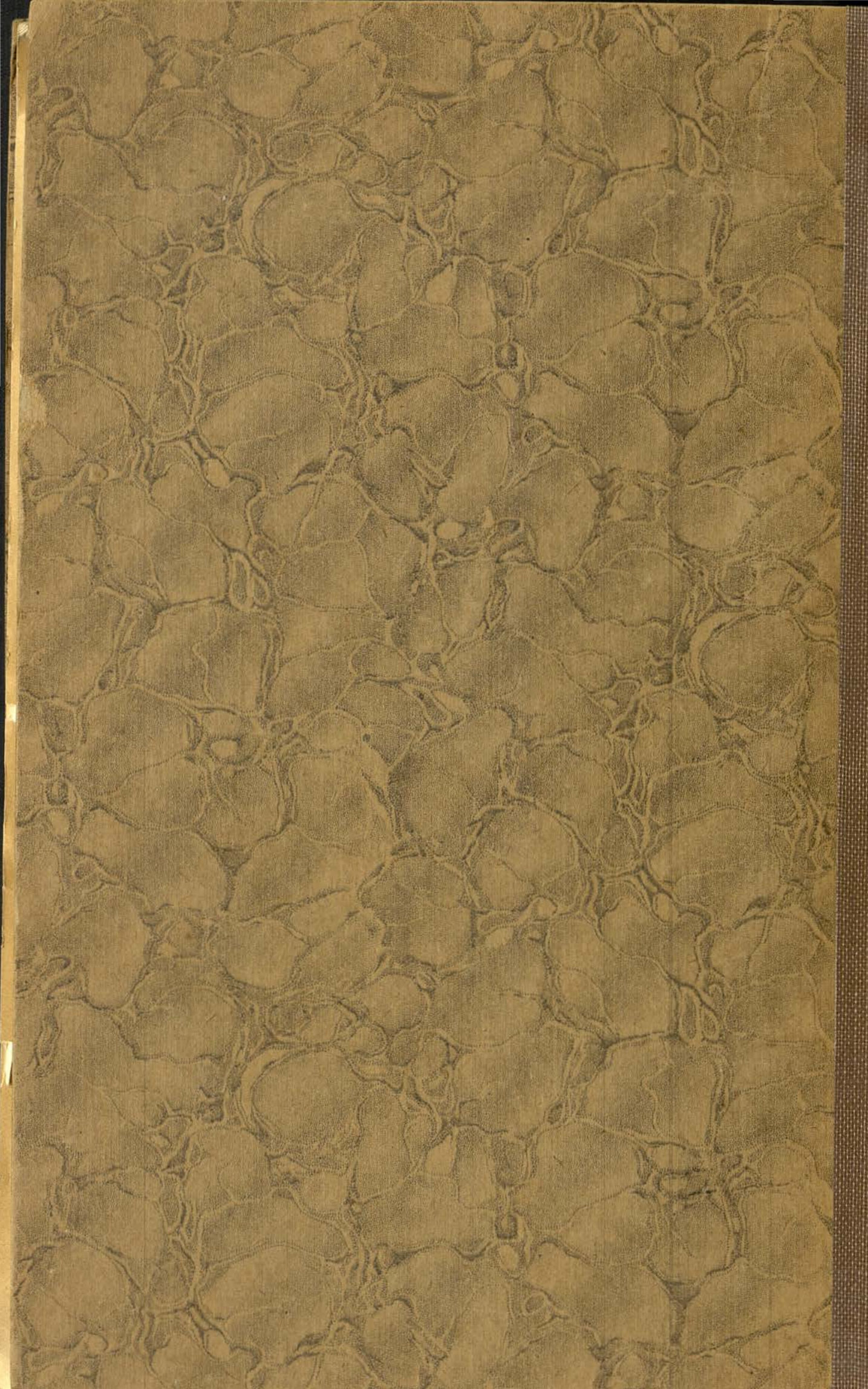

